\title{
NOXIOUS WEEDS IN EASTERN OREGON
}

\section{BUREAU OF LAND MANAGEMENT — OREGON STATE OFFICE}

OCTOBER 5, 1993 



\section{BLM Library \\ Denver Federal Center \\ Bidg. 50, OC-521 \\ P.O. Box 25047}

NOXIOUS WEEDS IN EASPERHE GREGON 225

Jerry Asher

$10 / 5 / 93$

SUMMARY BLM's noxious weed management program, in cooperation with the Oregon Department of Agriculture and local counties, has been steadily increasing in recent years. Much progress can be listed and success stories enumerated. However, given the rapid weed expansions underway, major increased efforts are needed. Eastern Oregon is not unique, weed experts in university weed science departments and state departments of agriculture along with many BLM personnel in 10 western states all agree that weeds are spreading rapidly and in some cases exponentially on BLM rangelands.

More than anything else, biodiversity and ecosystem health of rangelands depend on well functioning plant communities. Unfortunately, the single greatest threat to healthy rangelands and to the recovery of less than healthy rangelands is the rapid expansion of noxious weeds.

Noxious weeds are reducing the value of native wildlands, rendering wetlands and habitats nearly unusable by wildlife, reducing forage, increasing soil erosion, decreasing water quality, decreasing property values, reducing biological diversity and increasing the economic burden of maintaining recreation and wilderness areas.

Weeds prefer disturbed sites and well managed land is the best defense against the spread of weeds. However, weeds also commonly invade relatively undisturbed sites. Weeds are spread by vehicles, humans, horses, livestock, wind, water, and wildlife. While extensive infestations of certain weeds have already created "biological crises" in some areas of Oregon, these same weeds are at low population levels in other areas where they have the potential to become quite serious.

There are many economical and effective weed management strategies that can be implemented. The technology is well known and the greatest opportunities for weed management are when infestation levels are very low. Unfortunately, support for aggressive weed management is usually slow to develop until weed infestations become severe. To overcome this challenge, awareness programs and weed inventories are urgently needed.

All areas need Integrated Weed Management Plans, prepared cooperatively with all land owners, that include prevention, early detection, coordination, control and monitoring.

Yellow starthistle is an example of just one species that is clearly entering an exponential phase of growth. Pictures in the report provide a visual explanation of the weed management challenges and solutions. 

PURPOSE This paper seeks to explain that: 1.) Noxious weeds (hereinafter called weeds) are increasing rapidly on both disturbed and relatively undisturbed lands. Like most western states, there is an "explosion in slow motion" occurring on many lands in $E$. Oregon, 2.) Inventories to assess the locations and magnitude of weed infestations are lacking, 3.) Prevention of weed spread, combined with early detection and eradication of small infestations is urgently needed, and, 4.) There are many economical and effective weed management techniques that can be implemented.

MANAGEMENT STRATEGY Far more than anything else, biodiversity and ecosystem health depend on well functioning plant communities that hold soils, maintain soil fertility, and promote infiltration and safe release of water. Soil, air, water and animals are also very important components of the ecosystem. However, if a vegetation community is functioning well, all the other components of the ecosystem will usually also be functioning well.

Unfortunately, the single greatest threat to healthy rangelands and to the recovery of less than healthy rangelands is the rapid expansion of weeds.

The goal of weed management is to facilitate restoration and maintenance of desirable plant communities and healthy watersheds.

UNDERSTANDING THE WEED EXPANSIONS IN THE WESTERN STATES Weeds, primarily from Eurasia, began arriving in earnest to western rangelands in the 19th century. In Eurasia these species were generally not invasive because they evolved with a natural complement of insect predators, plant pathogens, fungi and competition from other plants. However, in the process of entering this country these plants were released from those natural controlling factors allowing them to be very aggressive.

Around the turn of the century, excessive disturbance of native plant communities caused by farming marginal lands as well as overgrazing combined with the accidental and intentional introduction of aggressive alien plants to set the stage for large populations of weeds. Immigrants brought crop seed that was often contaminated with weed seeds. Many of the plants we know today as noxious weeds were in seed catalogues that allowed immigrants to order seed from their homeland. Furthermore, we imported the Italian honeybee which is an effective pollinator of many weeds. Some weeds are allelopathic meaning that they produce a chemical that inhibits the growth of surrounding vegetation, thus giving them another competitive advantage.

Weeds are spread by vehicles, humans, horses, livestock, wind, water, and a wide variety of wildlife. For example, birds spread weed seed and leafy spurge is being spread by elk and deer in the Naomi wilderness area in Utah (Dewey 1993). Elk have been reported to eat knapweed seedheads (Lange 1993). It also has been shown that 

over $13 \%$ of spotted knapweed seeds pass undamaged through the digestive tract of mule deer (Wallander 1992). Ground squirrels were observed carrying knapweed seedheads into their burrows (Lange 1993).

Weeds prefer disturbed sites such as roadways, sites of mineral activity, overgrazed areas, trail heads, trails, wildlife bedgrounds and campgrounds. Well managed land is the best defense against the spread of weeds. However, recent literature and many observations make it clear that weeds also commonly invade relatively undisturbed communities. "Several exotic noxious perennial weeds, including spotted, diffuse and Russian knapweeds, leafy spurge, and yellow starthistle, are moving into excellent condition stands of native vegetation" (Harris 1991). Tyser and Key (1988) reported that spotted knapweed invaded and reproduced in rough fescue communities in Glacier National Park. Forcella and Harvey (1983) documented Eurasian weeds dominating relatively undisturbed grasslands in Montana. "Several exotic weeds will invade undisturbed climax communities and can become significant components of a community" (Bedunah 1992). While discussing the ecological equilibrium of native communities, Bedunah also noted: "that the introduction of exotic plants can throw this balance off, possibly forever."

The Nature Conservancy reports the invasion of noxious weeds into many disturbed and undisturbed bunchgrass communities in their Garden Creek Preserve in Idaho (Hill 1993). "Speculation by local land managers that dyers woad could eventually exist on most of the Cache National Forest in Utah, including the Mt. Naomi wilderness Area, is supported by the fact that the weed was observed on 55 of 60 possible land cover types" (Dewey 1991).

Kummerow (1992) stated that: "knapweed and leafy spurge crowd out native species, and like human populations, knapweed can increase exponentially beginning slowly, then doubling and redoubling." "Many of these exotics also show significant competitive advantage over natives. In the absence of predators, immune systems or other biological control mechanisms adapted to counteract these species, populations of some exotics have exploded" (Monnig 1992). The absence of natural fire processes could be causing environmental conditions that are more conducive to weeds. Knapweeds are spreading in natural area preserves in Washington, especially where soils have been excavated by burrowing animals but also where soil disturbance is absent. "This trend is particularly disturbing in high condition range sites. It is anticipated that invasion and spread of knapweeds will pose increasing ecological problems to preserve managers in the next decade" (Schuller 1992).

BLM conducted an evaluation of its nation-wide noxious weed program which indicated that weeds increased from $2.5 \mathrm{million}$ acres in 1985 to 6 million acres in 1991. Those are only estimates because inventories are lacking, but the estimates are considered 

conservative. Recognizing that weeds typically increase at $14 \%$ per year if unchecked, the increased infestation rate on BLM land is now approximately 2000 acres per day -- "an explosion in slow motion".

Spotted knapweed, first reported in Montana in 1920, has increased to over 4 million acres. Similarly, there are over 600,000 acres of leafy spurge in Montana. During the last 30 years, leafy spurge has increased from 200,000 acres to over 1 million acres in North Dakota. In S. Idaho, rush skeletonweed expanded from 40 acres in the early 1960s to over 4 million acres today! Also in Idaho, yellow starthistle increased during the last 30 years from just a few small patches to over 300,000 acres and a ten-fold increase is predicted (Callihan 1991). In SE Washington, yellowstar increased from approximately 1000 acres in 1954 to over 140,000 acres today (Roche 1993). Since 1977, yellow starthistle increased from 1 million acres in California (mostly N. Calif.) to over 10 million acres today.

Weed experts in university weed science departments and state departments of agriculture in 10 western states all agree that weeds are spreading rapidly, and in some areas exponentially, on rangelands. Additionally, weeds are quite capable of invading areas with low precipitation. For example, during the last 40 years squarrose knapweed increased from one acre to over 140,000 acres near Tintic Junction, Utah in an annual precipitation zone of as little as 6 to 8 inches. Furthermore this aggressive plant continued to expand during the seven year drought.

Squarrose knapweed was first identified in Utah and $\mathrm{N}$. California in the mid 1950's making it a more recent arrival in comparison to the weeds discussed thusfar. Sulfur cinquefoil, another example of a more recent arrival, was discovered in Montana several decades after leafy spurge and spotted knapweed. It is currently in an exponential expansion phase (Rice 1993). While we don't know how invasive new species will be, new weeds are arriving yearly at the rate of nine new species per state per year (0ld 1992)!

\section{IMPACTS FROM WEEDS}

THE ECONOMIC IMPACT CAN BE SEVERE

The economic loss from livestock production alone to Grant co. oregon in 1993, primarily from private rangelands, was approximately $\$ 247,680$. Without increased weed control efforts the economic loss just from the private lands is estimated to be 3.5 million dollars by 1998 (Test 1993).

A 1300 acre rangeland ranch near Klamath Falls oregon became so infested with leafy spurge that it was vacated in 1988 and sold at auction for ten percent of the value of surrounding properties without leafy spurge. The property is now off the tax roles. 

The State of Wyoming has spent over 20 million dollars for the control of leafy spurge, nearly all on rangeland, since 1978! (Whitson 1993).

The combined economic impacts of leafy spurge on rangelands in Montana, N. Dakota, S. Dakota, and Wyoming are substantial with direct and secondary economic impacts in 1990 approaching \$34 million and $\$ 76$ million, respectively (Bangsund 1991)

In 1955, Okanogan County, WA needed $\$ 1500$ for control of knapweed that had recently invaded. The request for funding was denied. In 1991, an estimated $\$ 1.5$ million was requested for 5 million acres.

\section{EROSION}

In Montana, comparisons were made between areas dominated by native bunchgrasses and areas dominated by spotted knapweed. Runoff was $56 \%$ higher and sediment yield was $192 \%$ higher from the areas dominated by knapweed (Lacey 1989).

POISONOUS/IRRITANT

Some weeds are poisonous to livestock, horses, and humans. others are very irritating to human skin causing itching and rashes. Thistles and knapweeds are painful to touch and are very undesirable along trails and in campgrounds.

FORAGE/HABITAT

Weeds often cause a substantial reduction in livestock and wildlife forage and wildlife habitat.

RARE PLANTS and ANIMALS

Weeds can replace rare native plants. Similarly, weeds can outcompete the native plants that rare animals need for survival.

WEED INVASIONS IN EASTERN OREGON An interagency task group prepared a Noxious Weed Strategy for Oregon/Washington BLM, and reported that: "The spread of noxious weeds, not only in oregon and Washington, but in many areas of the western United States, is reaching epidemic proportions in many areas. The encroachment of these alien, exotic, and invading noxious weeds is reducing resource value of agricultural croplands and native wildlands, rendering wetlands and habitats unusable by wildlife, increasing soil erosion, decreasing water quality, decreasing property values, reducing biological diversity, and increasing the economic burden of maintaining recreation and wilderness areas on public and private lands" (USDI 1993).

Weed populations are not yet as extensive in E. Oregon as they are in parts of some other western states. While the explanation for this difference is not clear, it is abundantly obvious that weeds 
a

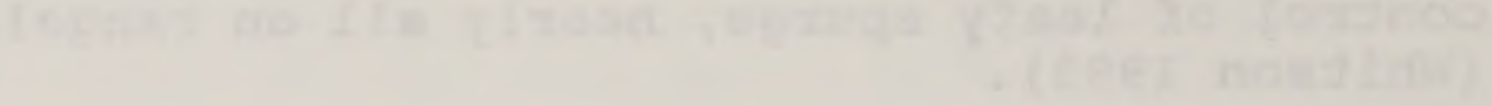

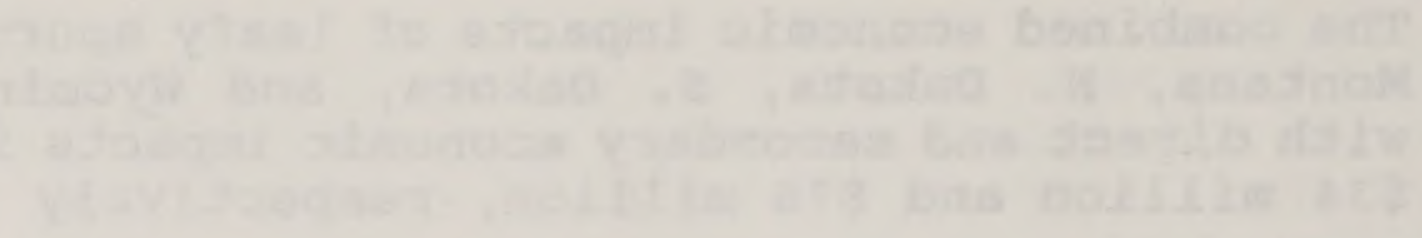

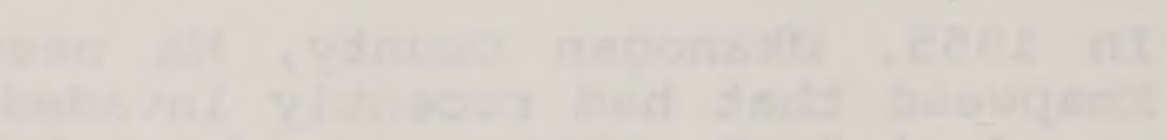

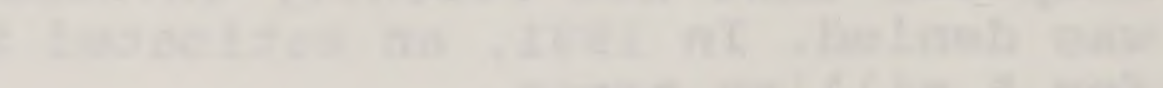

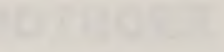

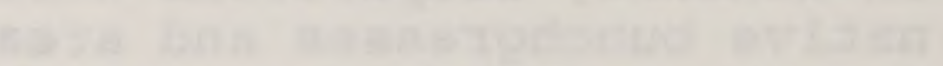

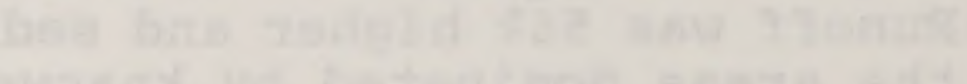

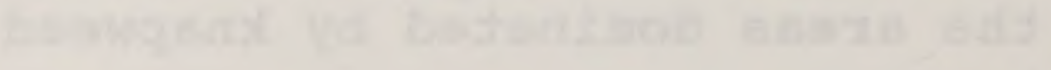

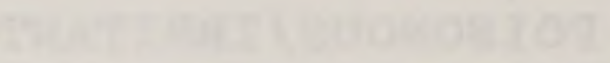

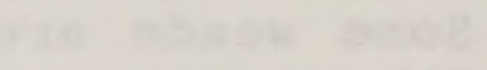

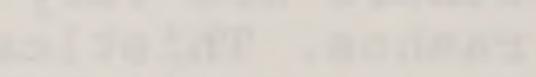

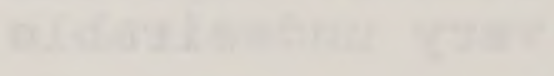


are currently making major advances in E. Oregon. For example, yellow starthistle increased during the last five years from 173,000 acres to over 286,000 acres in Umatilla county. In 1991, weed meetings were held in Klamath Falls, Lakeview, Prineville, Burns and Ontario to gain a better understanding of the weed situation. A good representation of people most knowledgeable about weeds including landowners, county weed coordinators, BLM managers and specialists, and state weed specialists, were in attendance at every meeting. "As evidenced from testimony at the Weed situation Meetings, noxious weeds are definitely spreading at an alarming rate" (Oregon Department of Agriculture 1991).

Many of Oregon's most valuable and productive lands (riparian areas, critical deer winter range, and prime recreation lands along the John Day, Deschutes, Grande Ronde, Snake, and Burnt Rivers, and the Warner Wetlands) are sites of rapidly expanding weed populations (USDI 1993).

Squarrose knapweed is just beginning to invade E. Oregon. Major infestations of squarrose have developed recently on sagebrush rangelands in Utah in the 8 and 6 inch precipitation zone. This weed is well adapted to the dry deserts of $\mathrm{E}$. Oregon.

All the weed experts in the western states are in total agreement that weeds are expanding rapidly on BLM rangelands. More specifically in E. Oregon:

"There is no reason that lands in E. Oregon are any less susceptible to knapweeds than the lands in eastern Washington" (Roche 1991).

"Yellow starthistle has the potential to become a serious noxious weed on one-half of E. Oregon lands" (Isaacson 1993).

"The probability of $\mathrm{E}$. Oregon developing weed infestations similar to Montana and Washington is quite high" (Larson 1991).

"I see a major change taking place in E. Oregon in the next 50 years. The aggressive spread of the knapweed complex into the Great Basin area (along with juniper)" (Eddleman 1991).

"Even though we have seen unprecedented improvements in range condition we are at or near a catastrophic shift toward weedy vegetation" (Krueger 1990).

SOLUTIONS While certain weeds are extensively established and out of control creating "biological crises" in some areas, these same weeds are at low population levels in other parts of the state where they have the potential to become quite serious. For example, knapweeds in Deschutes county infest over 100,000 acres while only minimal acreage is infested in Baker and Harney counties. 

Similarly, yellow starthistle now dominates over 110,000 acres in Jackson county while there is only one ten acre infestation just found last year in the Burns BLM District (which includes 3.5 million acres). Constant attention to weed management in these areas of small infestations can keep the knapweed and starthistle at very low levels.

It must be pointed out that the very small amount of knapweed and starthistle in the counties mentioned above is based on the best information available. Systematic inventories in those areas would probably detect more very small infestations which would be quite susceptible to economical control.

Most of the known weed sites on BLM lands are the result of chance observations by county weed or road crews, and by BLM personnel working on other projects. While this information is valuable and management of these populations should not be neglected, it is limited since it does not give the complete distribution information needed to manage weeds most effectively. A more proactive inventory would allow for the development of an effective management strategy for each species (USDI 1993).

The challenge of controlling weeds may seem overwhelming, but so would range management or wilderness management if viewed "everywhere all at once." However, on a watershed or management unit basis, with Integrated Weed Management (IWM), reaching weed management goals can be quite reasonable.

IWM includes: 1. Prevention, including education, awareness, and training to reduce or stop the spread of weed seed and other reproductive parts, by people, horses, livestock, vehicles, fire, mineral exploration and road maintenance equipment, hikers, etc.; developing inventory and monitoring strategies to detect new infestations; and, restoring sites most susceptible to weeds, preferrably with native plants.

2. Coordination with Federal, state, county, adjoining landowners, conservation and user groups.

3. Controlling or eradicating small infestations using grubbing or handpulling where appropriate, and herbicides when necessary; and, restoration where weeds are controlled.

4. Containment of large infestations with perimeter spraying and biological control.

Note: Prevention and coordination are the easiest, most effective, and most economical. Unfortunately, support for weed management is usually slow to develop until infestations become severe. HEREIN IIES THE CHALLENGE: to get enough of the right people to understand, support and provide the leadership to prevent weeds from becoming a serious problem. 


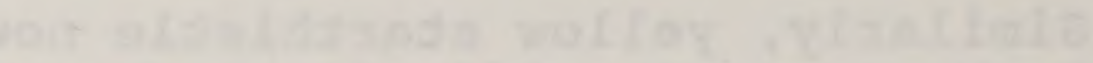

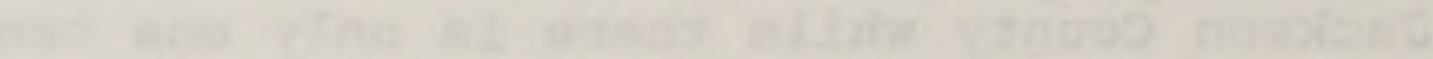

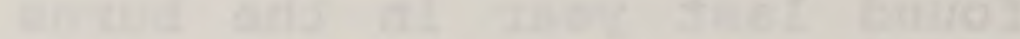
and

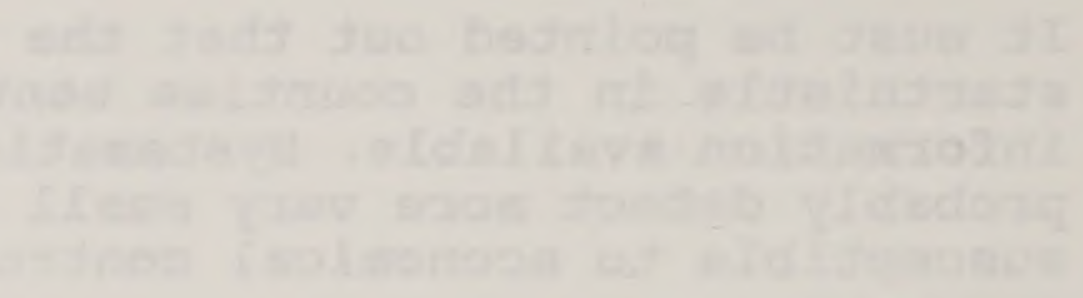

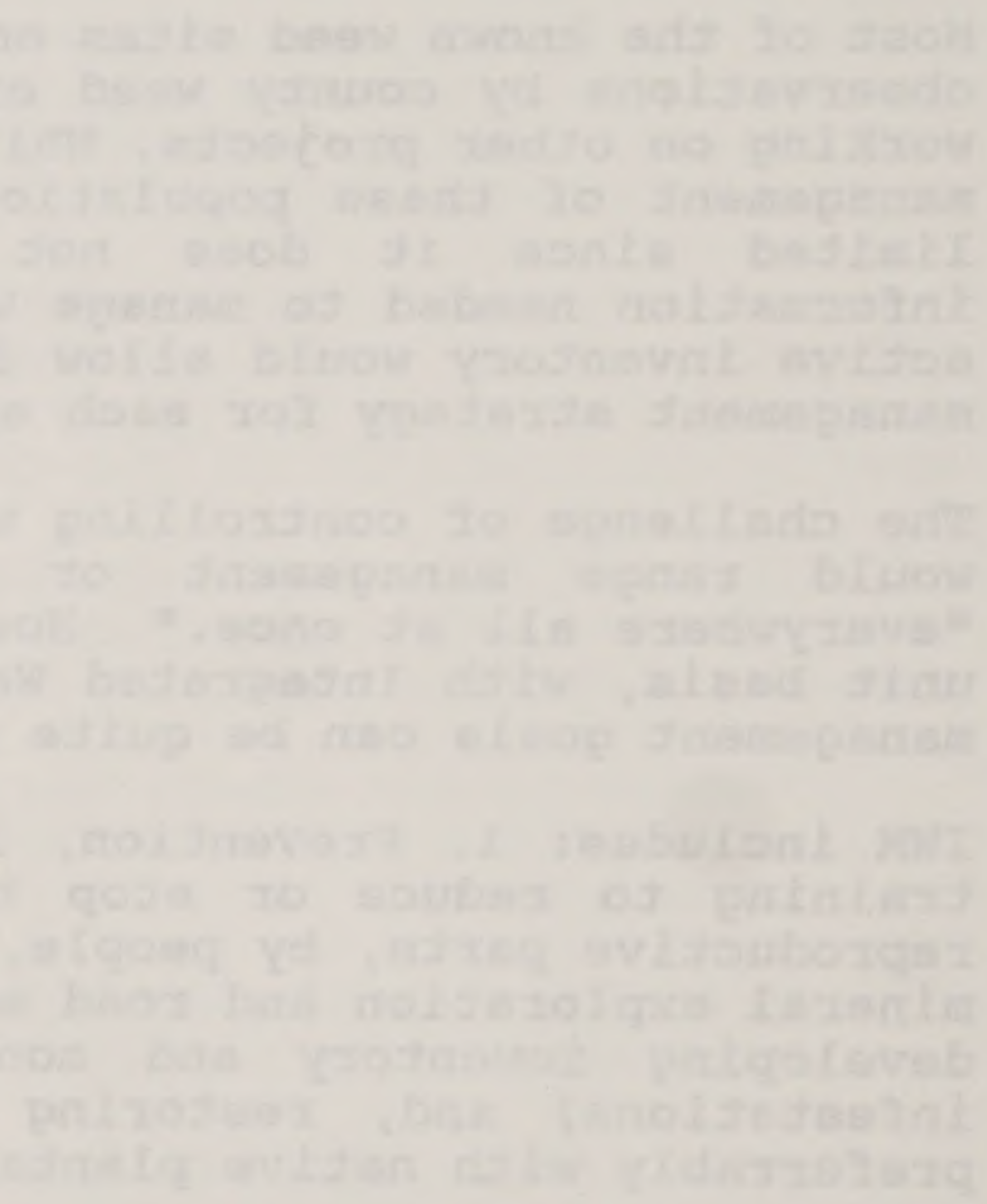

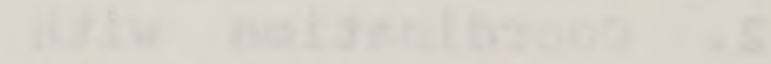

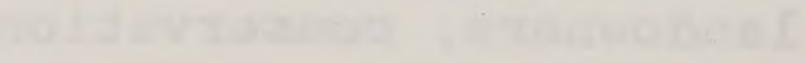

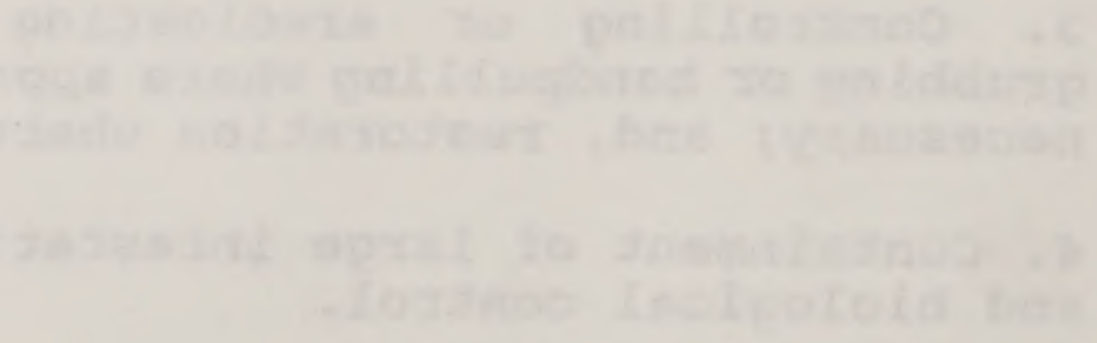

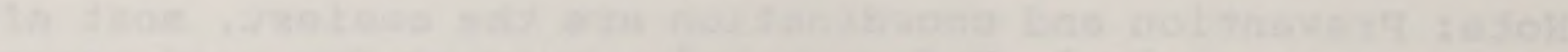
-

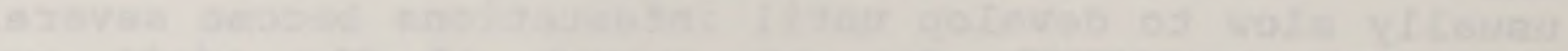

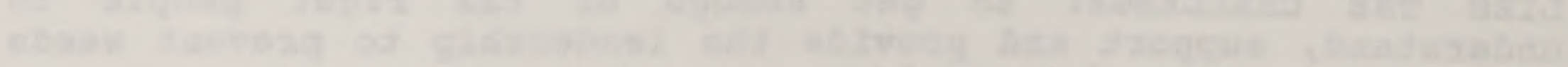

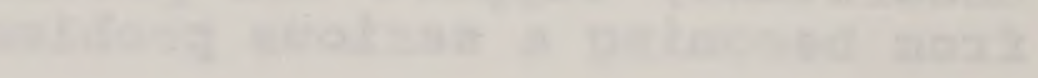


Because prevention, early detection, and eradication or control of early detected weeds are the most practical and effective means of weed management, lets look at examples of what that entails:

1. Education and awareness programs where visitors and users of the area assist managers in locating and identifying new invader species.

2. Development and enforcement of policies to ensure seed and seed mixtures, hays, grains, and straws are free of weed seed.

3. Require all user groups and BLM personnel to avoid or minimize the spread of weed seed.

4. Use contract clauses that ensure only certified and tested seed mixtures will be used to revegetate and reclaim disturbed sites.

5. Develop cooperative weed-prevention programs with suppliers of sand, gravel, top-soil, seed, hay, straw, and any other materials that may transport seed and reproductive parts of invader species, including nurseries that grow and sell ornamental plants.

6. Work with county and city planning staff and zoning committees to include consideration for noxious weed management when developing or approving subdivision plans, permits, etc.

7. Conduct systematic and periodic inventories.

The technology and tools for IWM are well developed, available, and effective except for two critical elements that need substantial improvement and investment: 1.)Biological Control, 2.) Restoration with native plants.

Biological controls offer the only promise for long term suppression of noxious weeds on areas with very large infestations. Substantially more investments are needed now. Much more effort is needed in the collection and distribution of approved biocontrol agents (insects) and in the development of new biocontrol agents. For example:

Medusahead, an annual grass, is one of the most serious and wide spread noxious weeds in E. Oregon and surrounding states. Unlike most other weeds, effective control strategies to prevent spread and restore infested areas are not available. However, a new possibility is on the horizon. A recent study indicates that an endemic soil-borne fungal pathogen may be an effective control for medusahead (Grey 1993). 
.

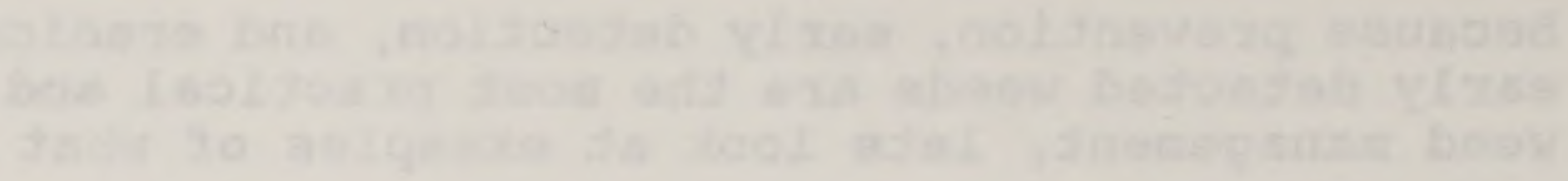

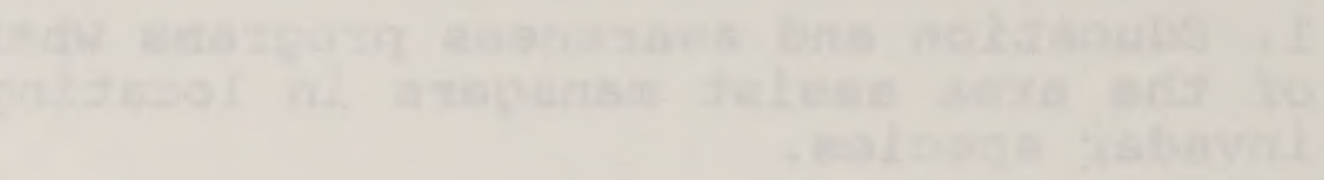

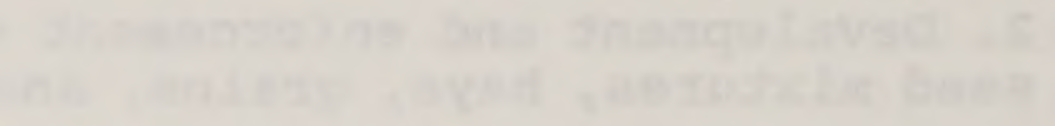

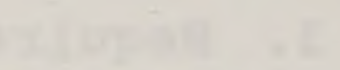

mina

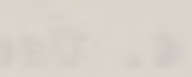

$x^{2}=x^{2}=$

$30 x^{2}=$
\end{abstract}


Yellow starthistle All indications, from the major infestations of surrounding states to the small and large infestations in eastern oregon, are that yellow starthistle is at the beginning of an exponential phase of expansion in eastern oregon. This species is potentially menacing to rangelands because of its ability to spread rapidly and colonize on disturbed soils. It forms dense infestations and exhibits an allelopathic effect on associated species, therefore reducing the available forage. Furthermore, starthistle has the capacity to adapt to different local environmental conditions (Maddox 1981).

Organized inventories in areas where yellow starthistle is likely to spread or is spreading are urgently needed so control activities can be initiated in a timely and strategic manner.

Where major infestations already exist, biocontrols may be able to slow the spread of starthistle by reducing the seed levels. Yellow starthistle populations are already extensive in Jackson County, Klamath River Canyon, south west of Mitchell, and parts of Baker county. Biocontrols may offer the only hope of bringing these established infestations down to manageable levels.

Seed feeding biocontrol agents are systematically being distributed by the Oregon Department of Agriculture, however substantially increased effort is needed in the following areas:

1.) All areas where intensive treatment of yellow starthistle infestations is not a feasible approach should have biocontrol agents released as soon as possible. One agent, Urophora sirunaseva, a seedattacking $f l y$, is now available for massive distribution. Broad base, all ownership participation in the collection, packaging, selection of release areas, release reporting, and monitoring of releases are needed. similar efforts are needed for other biocontrol agents that will be available in the next 2-5 years.

2.) In addition to the insects that feed only on the seed, biological control agents that attack the vegetative parts of yellow starthistle need to be obtained. Scientists with the Agriculture Research Service also need to conduct research to determine under what conditions the current biocontrol agents might be more effective (Turner 1993).

3.) Work on rusts that would attack yellow starthistle and other related weeds needs to be funded. 


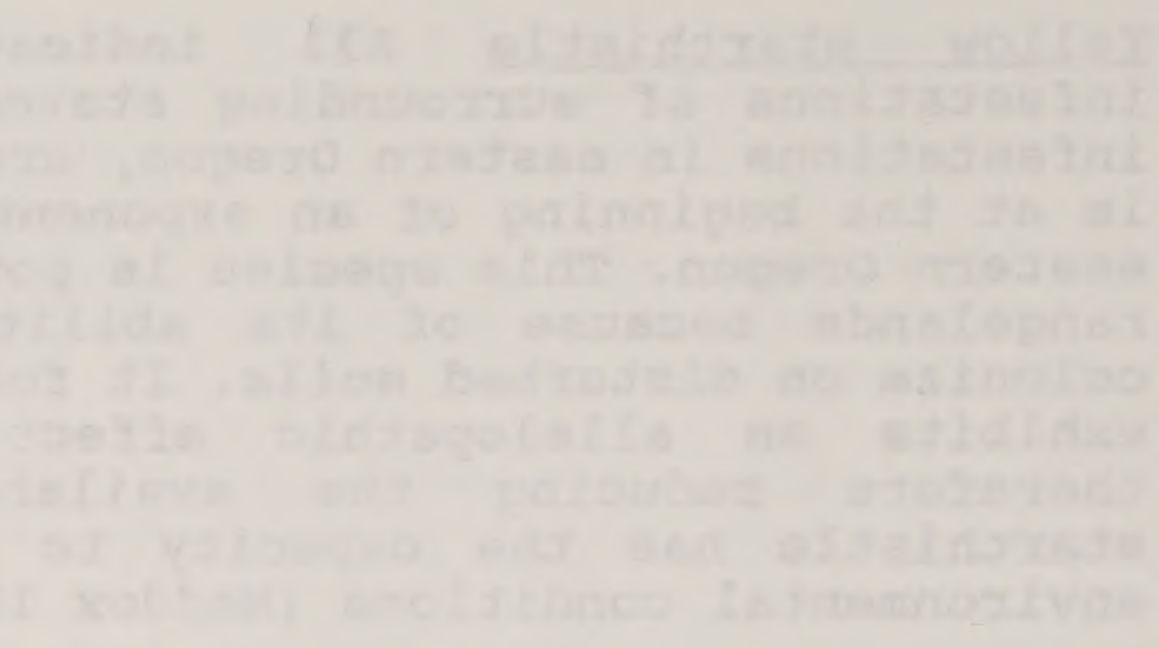

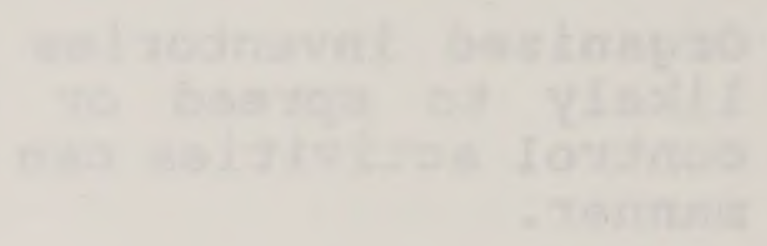

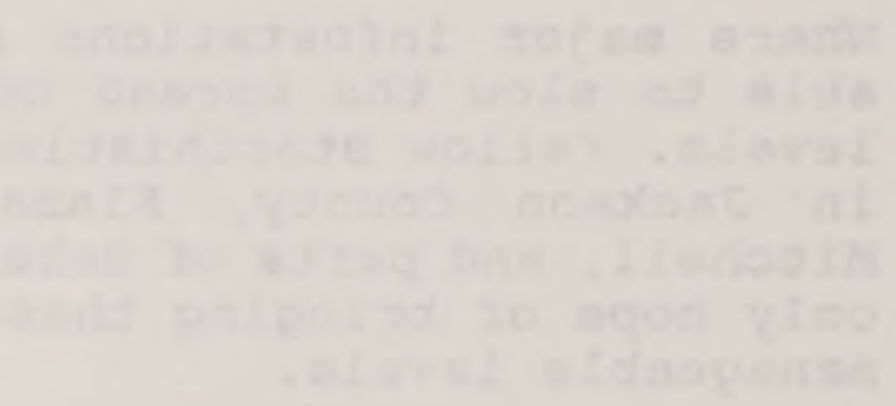

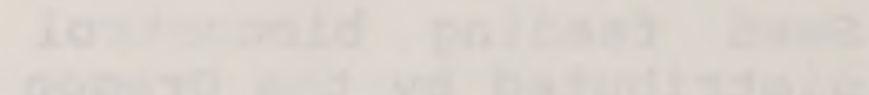

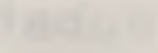
$x^{2} \cdot a_{1}$

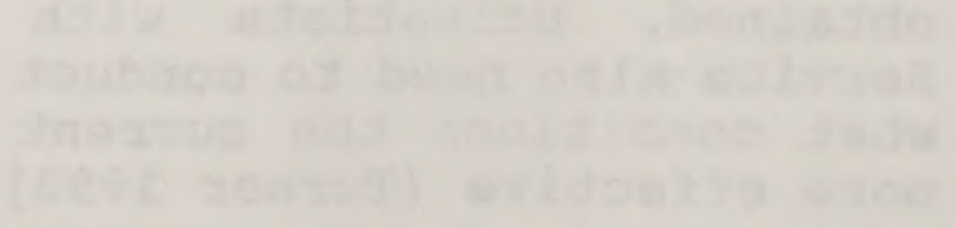

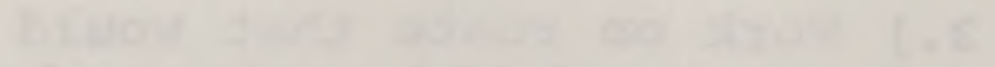

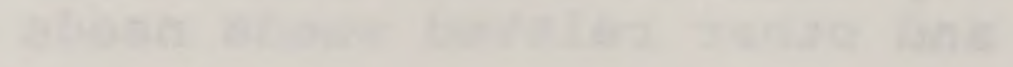


Skeletonweed, Leafy Spurge, Knapweeds Even though all of these weeds are well established in some areas, they are just beginning to spread to other remote areas where they have the potential to become very serious. Detection and prompt control work are urgently needed in these expansion areas.

Where large infestations already exist, many biocontrol agents for these weeds are available for distribution.

A cooperative project was underway by the commonwealth Scientific and Industry Research Organization of Australia to find Puccinia biocontrol biotypes for oregon skeletonweed. USDA-ARS support for this project ended. This is an economical effort with a fairly high probability of finding some agents that would be effective. The project needs to be reinstated.

The ability to restore disturbed sites that are susceptible to weed invasions, and to replace weeds that are controlled with native plants is critical to any long term weed management strategy. We know how to establish crested wheatgrass (a desirable exotic perennial grass) on disturbed sites to replace or control weeds. This is often a necessary interim strategy to prevent the establishment of weeds on disturbed sites, or to prevent reinvasion of weeds that have been controlled. However, biological diversity and ecosystem health require a wide variety of native grasses, forbs, shrubs, and sometimes trees. In the arid environments of eastern Oregon, the technologies are not yet well developed for re-establishing these native plants. Research is needed to improve our ability to meet this native plant restoration challenge. The Vegetation Diversity Project (BLM/NBS) is a research and demonstration effort already underway to develop these restoration techniques. Unfortunately it is only funded at about one-third the level required to make significant progress during the next ten years.

The "Guidelines for Coordinated Management of Noxious Weeds in the Greater Yellowstone Area" (USDI--USDA 1992), includes excellent examples of all phases of IWM. Using this as guide, a long term, consistent, and focused weed management program is essential for all local areas. The all important prevention, education, training, detection, and control activities will require almost full time attention by someone at the district level. Because all management activities are involved in the spread of, and are negatively impacted by weeds, all activities could share the funding for a weed management position.

EXAMPLES OF WEED MANAGEMENT STRATEGIES AND SUCCESSES The following discussion, examples, and pictures, will illustrate that prevention and control techiniques can be effective. Some weeds, like spotted and diffuse knapweed or yellow starthistle, are relatively easy to control if they are in small patches. However, it is nearly impossible to remove significant patches of leafy spurge that are 

over three years old. Therefore, it is essential to treat small infestations of leafy spurge to prevent it from producing seed that can be carried to other areas. It is critical in the successful control of new weed infestations to minimize the time interval between introduction and detection (Moody 1988). "After weed infestations reach a 'critical mass' they are uncontrollable in any practical sense" (USDA EIS 1993).

In Sanpete County Utah in 1934, a few patches of leafy spurge were found. Control work commenced immediately and the leafy spurge was eradicated. Today there is no leafy spurge in sanpete county.

Rushskeleton weed control along the Deschutes River is another example of success. Five years ago this weed was noticed in many patches over a ten mile stretch along the river. Immediately an aggressive control effort was undertaken. For two thousand dollars per year for three years followed by a few hundred dollars each year for monitoring, a $46 \mathrm{mile}$ stretch of the Deschutes River is now essentially clean of rush skeleton weed.

Tansy ragwort is another example of what can happen when people are determined to control a weed species. In 1979, the oregon Department of Agriculture established a goal of no tansy ragwort in E. Oregon (biocontrol that works so well in $W$. Oregon is not effective in E. Or.). They executed a program of detection and early treatment. Of the 1000 sites found so far, about one-half have been eradicated and the others are under control and being monitored. New sightings have dropped from about 90 per year in 1979 to only 15-20 now.

On January 1, 1994 all National Forest Lands in Utah will be closed to all feed (hay, pellets, etc.) not certified as weed free.

Temporary closures to public access are sometimes needed to prevent weed spread by human activities. For example, an order was published in the Federal Register in 1992, to prevent the spread of knapweed by motorized vehicles in a specific area of BLM land in Wyoming (Federal Register 1992).

CONCLUSION Noxious weeds are clearly moving fast in both disturbed and relatively undisturbed BLM lands in E. Oregon. They can have a profound influence on the value of these lands to future generations. To protect this value, aggressive control efforts are needed immediately where weeds are at the "now or never" stage and similarly, in areas where weeds are just arriving or are expected in the near future. Prevention plans must be developed before the easy/cheap opportunities are missed. Inventories, on BLM land and adjacent lands, are urgently needed to assess the potential for weed spread.

Except for some elements of biocontrol, the technology and tools are available to manage and control noxious weeds. There is no 

mystery involved here, it just takes the will, priority, funding and commitment of the right individuals.

Weed management plans are needed for all areas to facilitate an organized, long term effort. And, we don't need to do it all ourselves. There are many people willing to help, especially with inventories and some hand pulling. As user groups, conservation organizations, and agency people see themselves as both part of the problem and part of the solution, a cooperative, enthusiastic atmosphere will prevail.

I will end with a quote from Gordon Ash, wilderness ranger at Big Prairie in the Bob Marshall wilderness. The quotation applies to the hundreds of situations in $E$. Oregon where just a few weeds are noticeable and people who visit those areas usually wonder how serious the weeds might get. Gordon was on a field trip when someone asked about a few weeds they had noticed. He noted: "We don't know how far weeds will go in here, but if we don't get after them quickly, we are going to find out!" 



\section{REFERENCE8}

Bangsund, D.,Leistritz, F., 1991. Economic Impacts of Leafy Spurge on Grazing Lands in the Northern Great Plains. Agric. Economics rep. No. 275-S. Dep. Agric. Economics, N. Dakota State Univ.

Bedunah, D. 1992. The Complex Ecology of Weeds, Grazing and Wildlife. Western Wildlands $18:(2)$.

Callihan, R., J. Evans. 1991. Weed Dynamics on Rangeland. Noxious Range Weeds, pp. 55-61. James F.J. et. al. Westview Press.

Cheater, M. 1992. Alien Invasion. Nature Conservancy. Sept./Oct.

Dewey, S.A., K.P. Price. 1991. Satellite Remote Sensing to Predict Potential Distribution of Dyers Woad. Weed Technology $5: 479-484$.

Dewey, S.A. 1993. Personal Communication. Assoc. Prof., Plant, Soils and Biometerology Dept., Utah St. Univ., Logan, Utah.

Eddleman, L.E., 1991. Letter 2/22/91. Associate Professor, Rangeland Resources, Oregon State University.

Federal Register. 10/22/92. Closure of Public Lands. Vol. 57. No. $206, \mathrm{pg} .48392$.

Forcella, F., S.J. Harvey. 1983. Eurasian Weed Infestation in W. MT in Relation to Vegetation Disturbance. Madrono 30:(2) 102109.

Grey, W.E., Quimby, P.C., Young, J., Svejcar, T. 1993. In Press. Potential use of soil-borne pathogens as biocontrol agents to control grassy weeds in the Great Basin Region of the U.S.

Harris, G.A. 1991. Grazing Lands of Wa. St. Rangelands 13:222227.

Hill, J. 1993. A Weed Control and Revegetation Plan for Garden Creek Preserve. The Nature Conservancy of Idaho.

Isaacson, D. 1993. Personal Communication. Program Supervisor, oregon Department of Agriculture, Salem, Oregon.

Kummerow, M. 1992. Weeds in Wilderness: A Threat to Biodiversity. Western Wildlands 18:(2).

Krueger, w. 1990. Letter 12/31/90. Department Head, Department of Rangeland Resources, Oregon State University. 
(n)

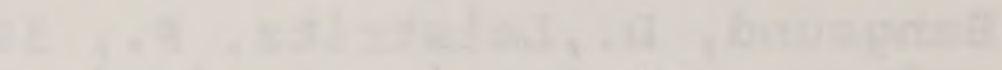

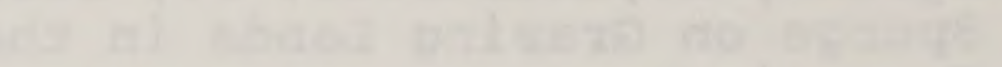

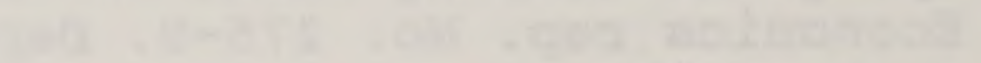

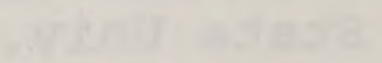

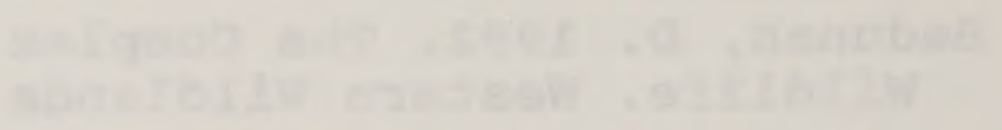


Larson, L. 1991. Letter 4/30/91. Associate Professor, Department of Rangeland Resources, Oregon State University.

Lacey, C. 1989. Knapweeds--The Situation in Montana. Range Weeds Rev. Symposium Proceedings, 1989 PNW Range Mgt. Short Course.

Lacey, J.R. 1989. Influence of Spotted Knapweed on Surface Runoff and Sediment Yield. Weed Technology 3:627-631.

Lacey, J, P. Husby, and G. Handi. 1991. Spotted Knapweed Invades Ungrazed Bunchgrass Communities. Knapweed 5:(2).

Lange, D. 1993. Personal Communication. Resource Management Specialist, Glacier National Park, West Glacier, Montana.

Maddox, D.M. 1981. Introduction, Phenology, and Density of Yellow Starthistle in Coastal, Intercoastal, and Central Valley Situations in California. USDA., Agric. Res. Serv., Ag. Res. Results no. Arr-W-20 33 pp.

Monnig, E. 1992. Pesticides and Human Health: The Complexities of Risk. Western Wildlands $18:(2)$.

Moody, M.E., and R.N. Mack. 1988. Controlling the Spread of Plant Invasions: the Importance of Nascent Foci. J. Appl. Ecol. 25:1009-1021.

Old, R. 1992. Noxious Weeds Invading Nation At An Alarming Rate. Vegetation Manager VI: (4).

Oregon Department of Agriculture 1991. Letter, February 1, 1991.

Rice, P.M. 1993. Personal Communication. Research Specialist, University of Montana, Missoula, Montana.

Rice, P.M. 1991. Sulfur Cinquefoil: A New Threat to Biological Diversity. Western Wildlands 17:(2).

Roche, B. 1991 \& 1993. Personal Communication. Extension Range Management Specialist, Washington State Univ., Pullman, Wa.

Schuller, R. 1992. Knapweeds Invade Nat. Areas. Knapweed 6:(4).

Test, Peter, S., 1993. Economic Value of The Grant County Weed Program To Livestock Production.

Turner, C.E., Johnson, J.B., McCaffrey, J.P. 1993. Yellow Starthistle (for: Biological Control in the U.S. Western Region: Accomplishments and Benefits of Regional Research Project $\mathrm{w}-84$ ) In Press. 

Tyser, R.W., C.H. Key. 1988. Spotted Knapweed in Natural Area Fescue Grassland: An Ecological Assessment. NW Sci. 62:151-160

U.S. Dept. of Ag. 1993. Flathead Nat. Forest Noxious Weed Draft Env. Impact statement, pp. 4-15. Forest Service. Kalispel MT.

U.S. Dept. of Interior. 1981. Wilderness Management Policy. BLM

U.S. Dept. of Interior. 1991. Situation Report on Undersirable Vegetation for eastern oregon/Washington BLM.

U.S. Dept. of Interior. 1991. Record of Decision. Vegetation Treatment of BLM lands in Thirteen Western states.

U.S. Dept. of Interior. 1993. Noxious Weed Strategy for Oregon and washington BLM.

U.S. Dept. of Interior and Agriculture. 1992. Guidelines for Coordinated Mgt. of Noxious Weeds--Greater Yellowstone Area.

Wallander, R., B. Olsen, J. Lacey. 1992. Passage of Spotted Knapweed by Sheep/Mule Deer. Wa. Knapweed Newsletter 6:(4) 1-2.

Whitson, T. 1993. Personal Communication. Extension Weed Specialist, University of Wyoming. 


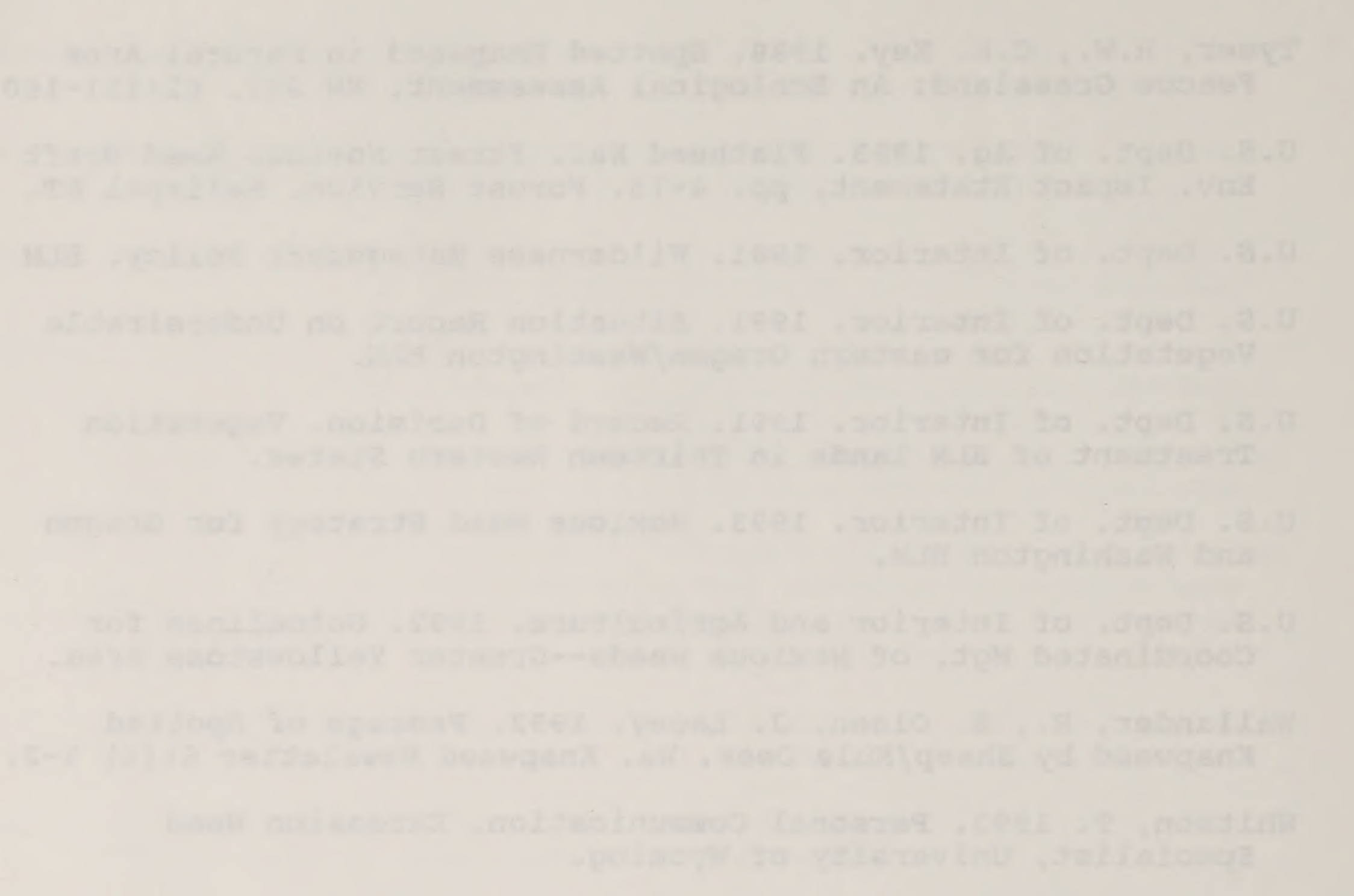


NOTES TO THE READER/VIEWER OF THE FOLLOWING PICTURES

The following pictures and captions are intended to represent many of the weed situations in eastern oregon. To reduce repetitive sentences, the term: "IWM needed" in the captions means Integrated Weed Management plans are needed that include prevention, detection, control, coordination and monitoring. Usually IWM plans are needed to encourage and guide the effective long-term weed control efforts on BLM lands and surrounding lands of all ownerships.

Please recognize that there are vast areas of land involved and weed management activities are taking place at various BLM locations throughout eastern oregon where funding and workforce are available. While the term "growing unchecked" occurs in some of the picture narratives to indicate that many infestations are not being controlled, weed management efforts are underway in many other parts of all the districts.

PLEASE KEEP IN MIND, that after studying all the pictures a person may feel overwhelmed with the weed management challenges. That is because these pictures are a "concentrated view" of infestations. Remember that the vast majority of BLM lands are not significantly infested with weeds -- yet. On a watershed, planning unit, or resource area basis, effective weed management can be a reasonable endeavor. 

17

UNDERSTANDING THE NOXIOUS WEED SITUATION 



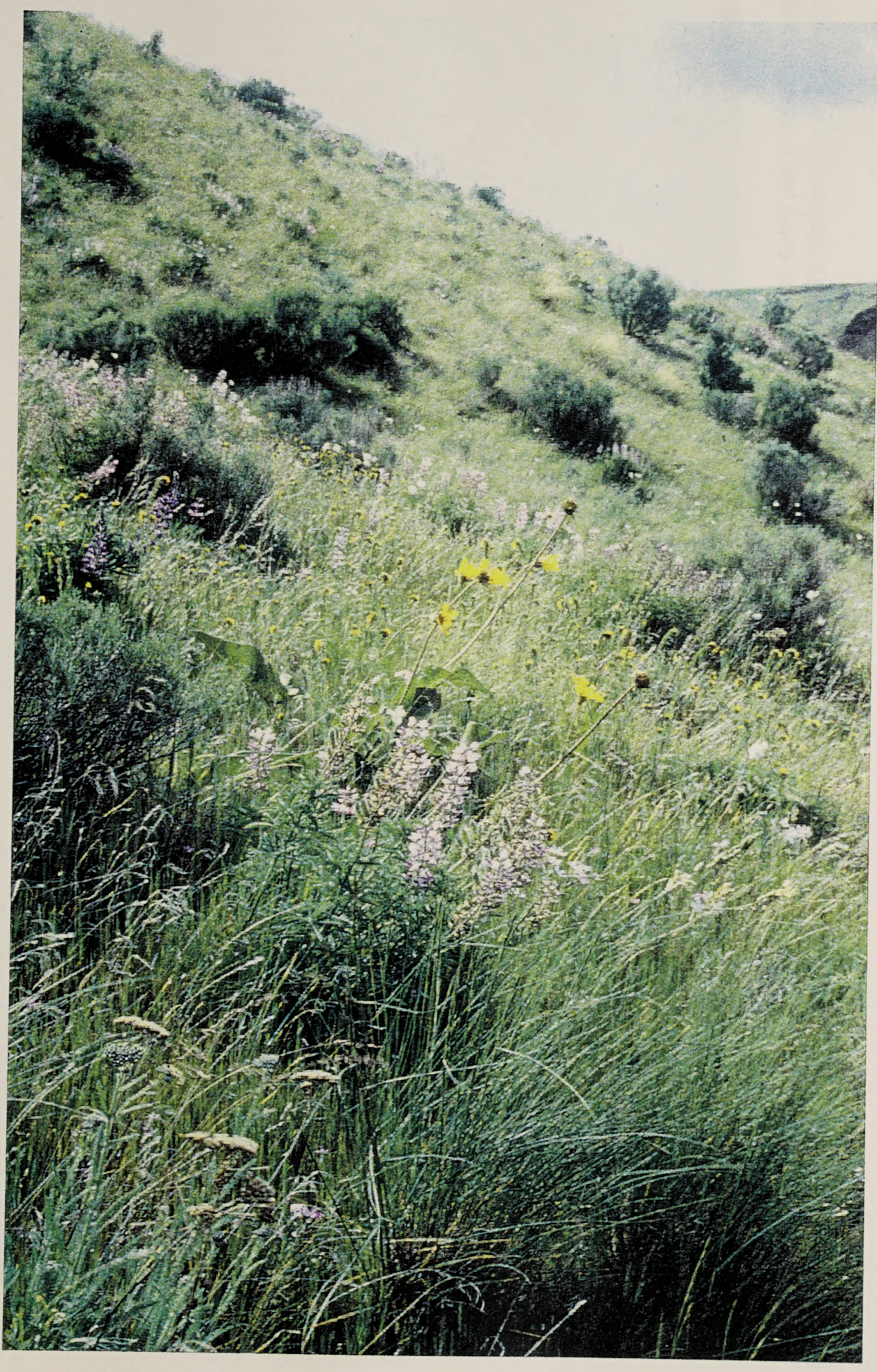

HEALTHY VARIETY OF GRASSES, FORBS, AND SHRUBS (Prineville District). Far more than anything else, biodiversity and ecosystem health depend on well functioning native plant communities that hold soils, maintain soil fertility, and promote infiltration and safe release of water. Healthy plant communities are the first 



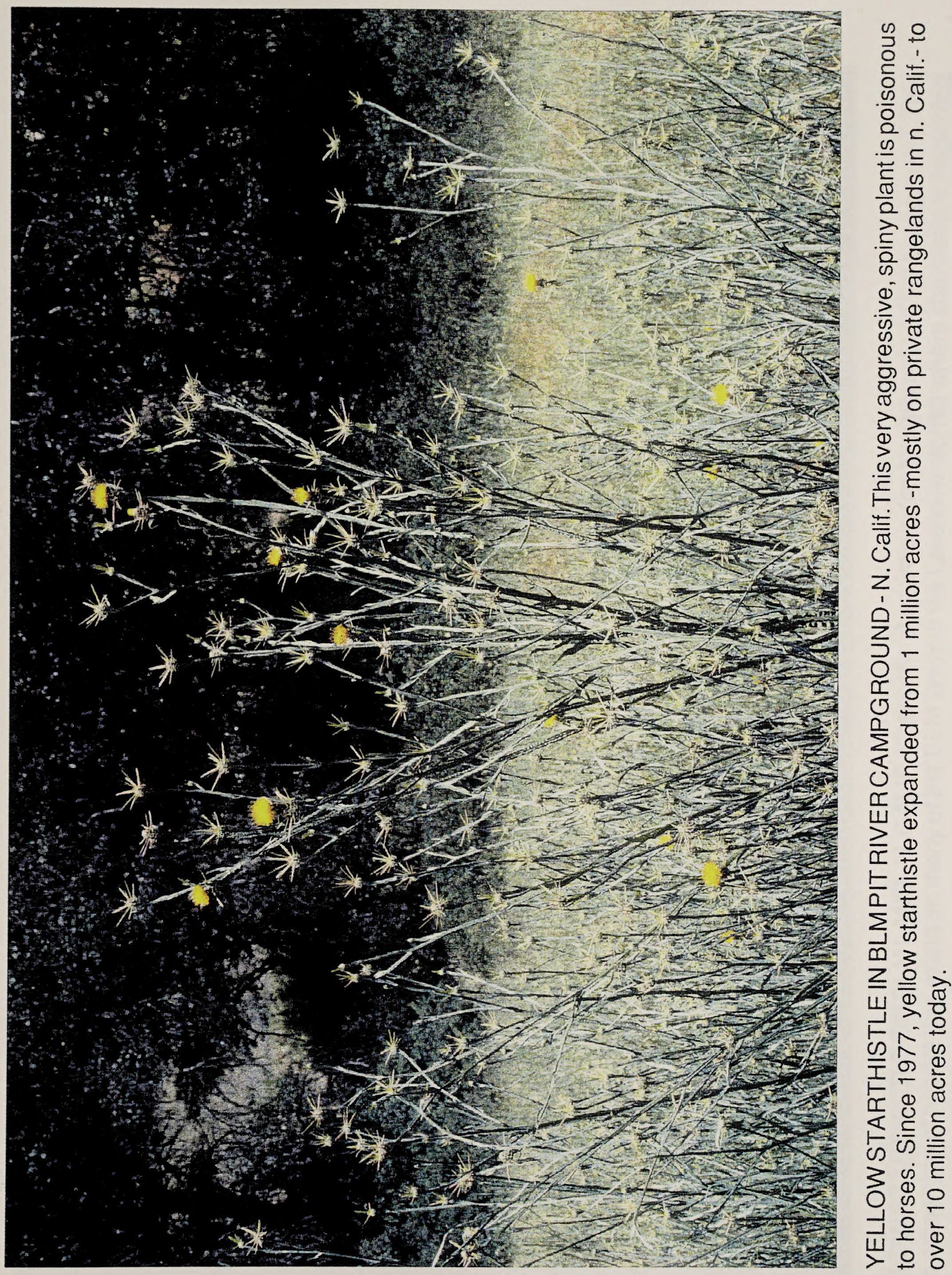





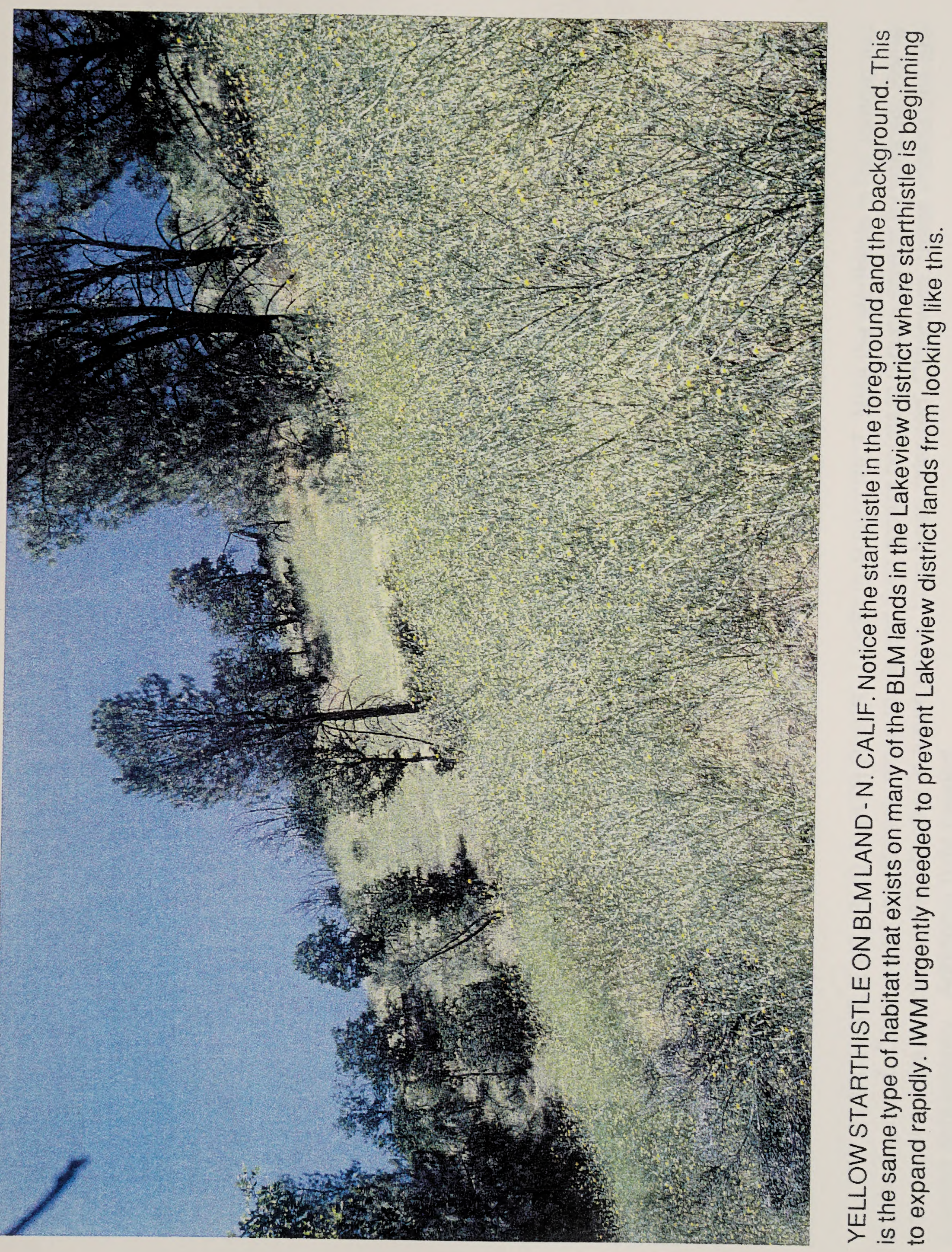





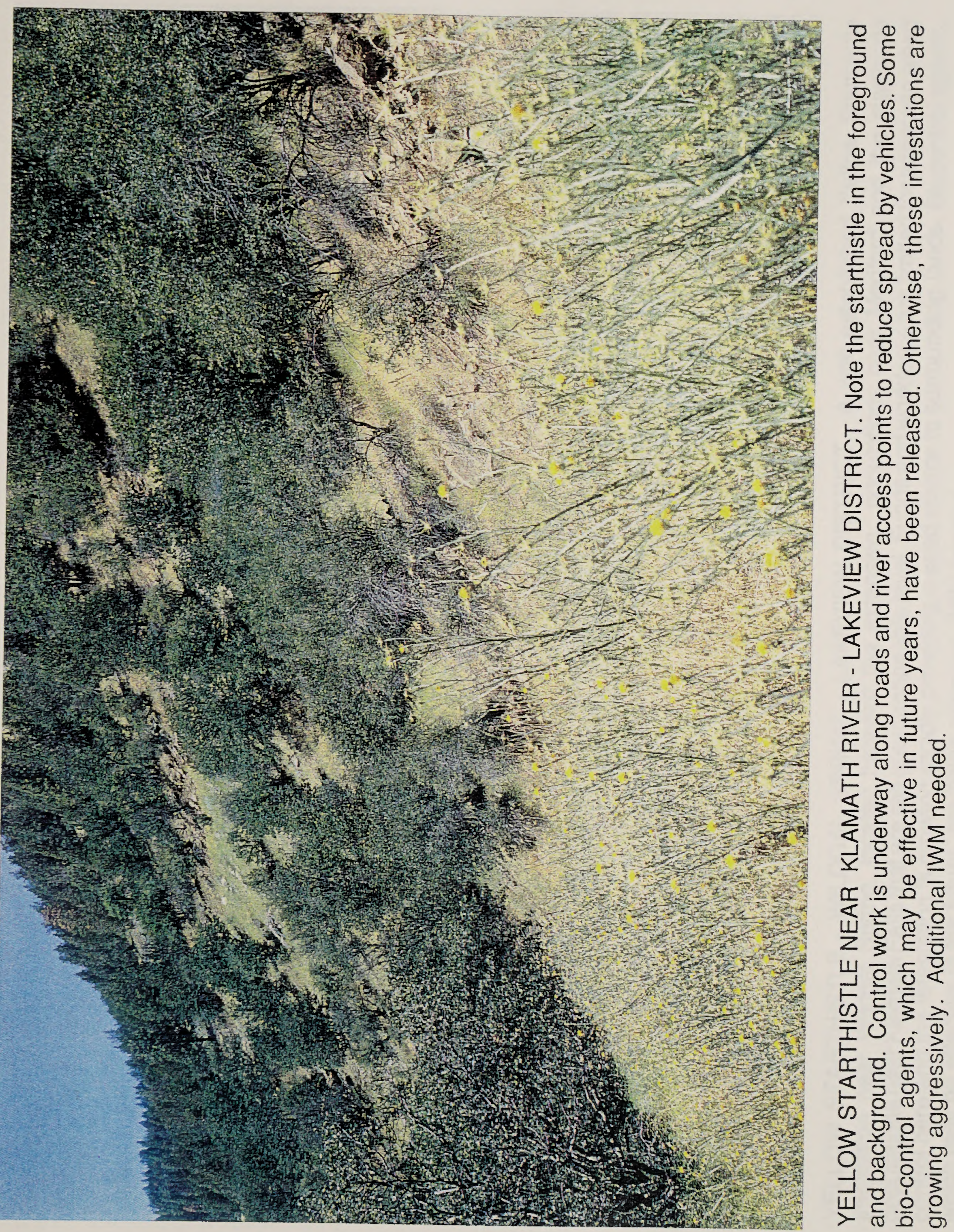





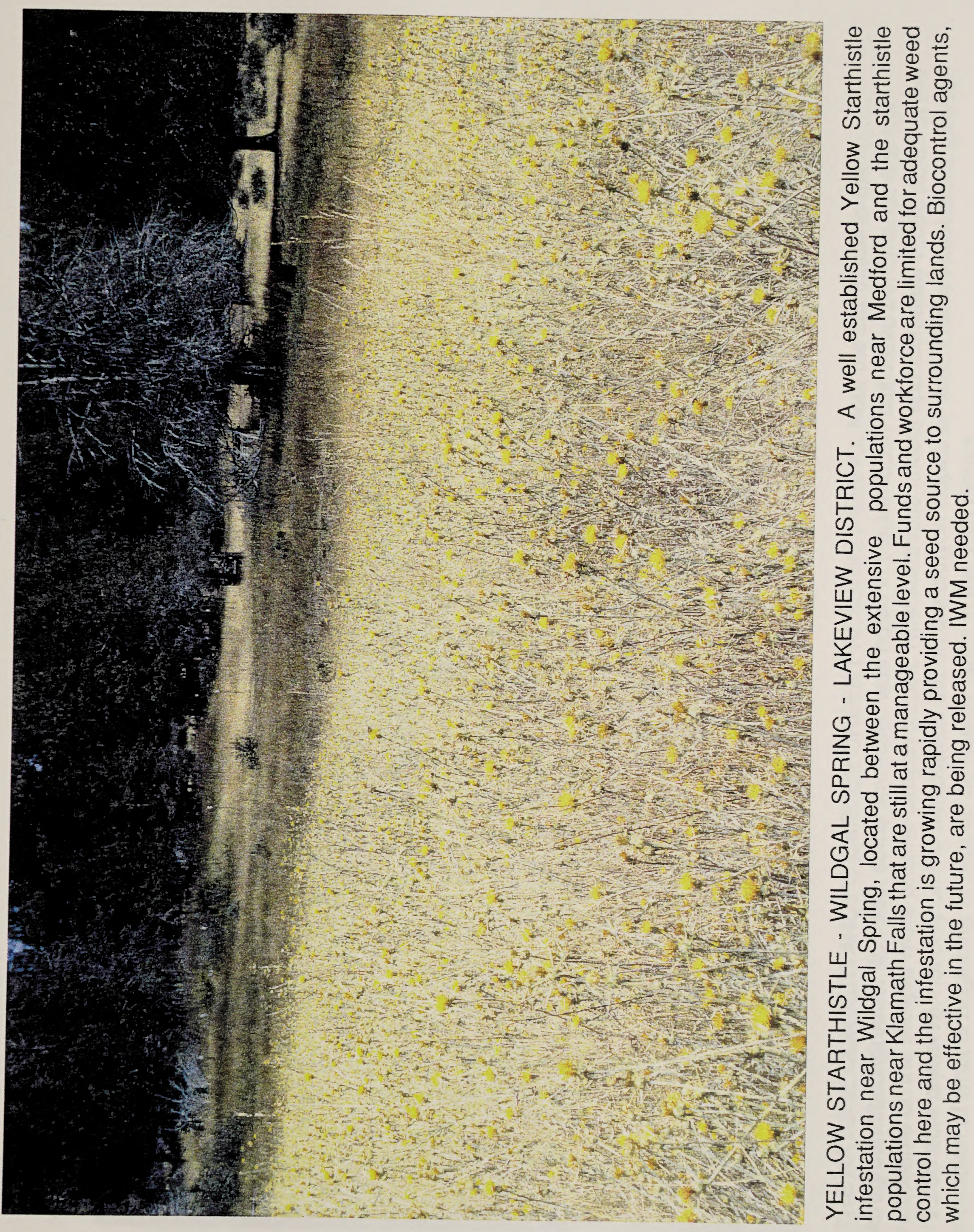





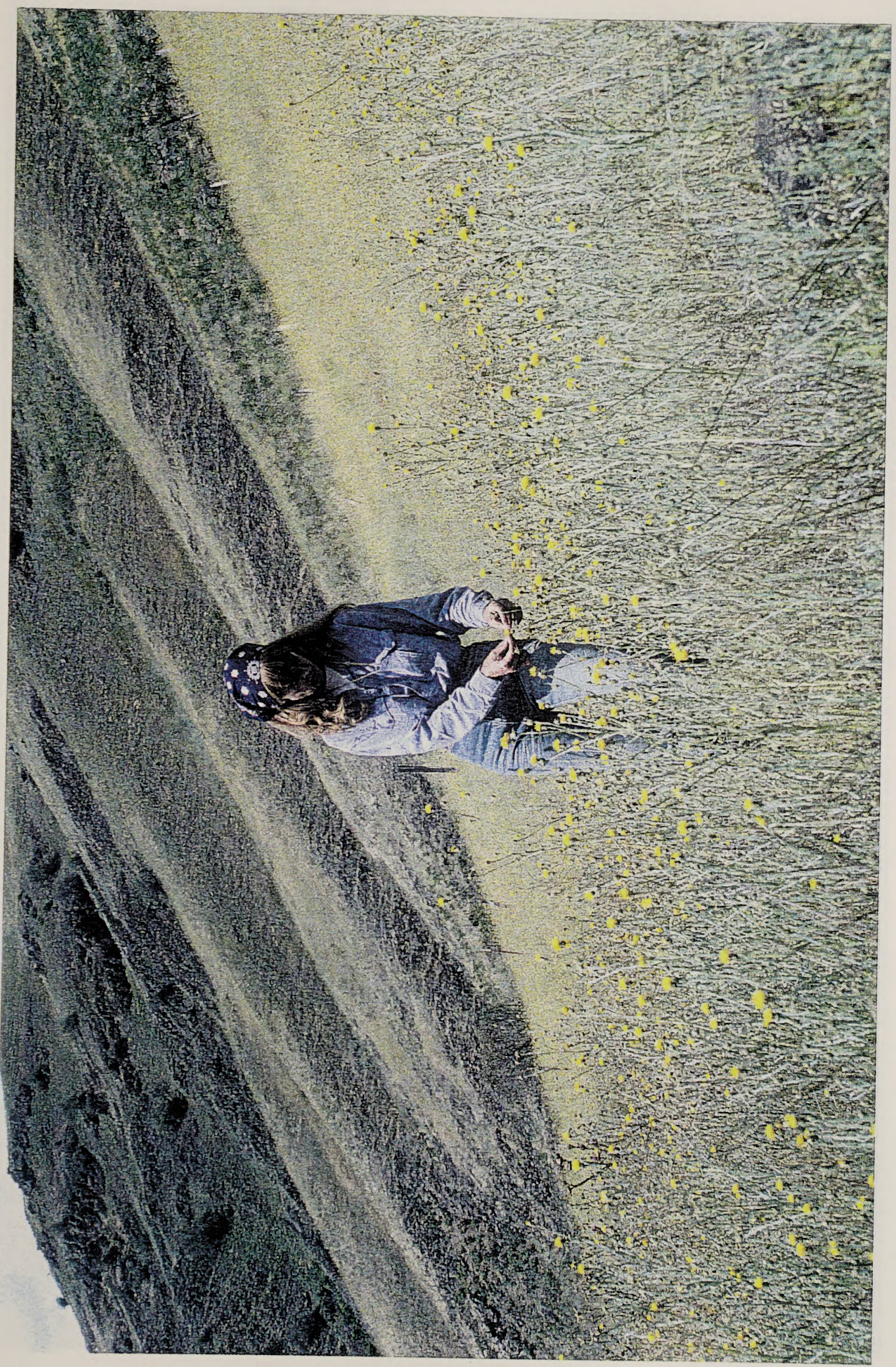

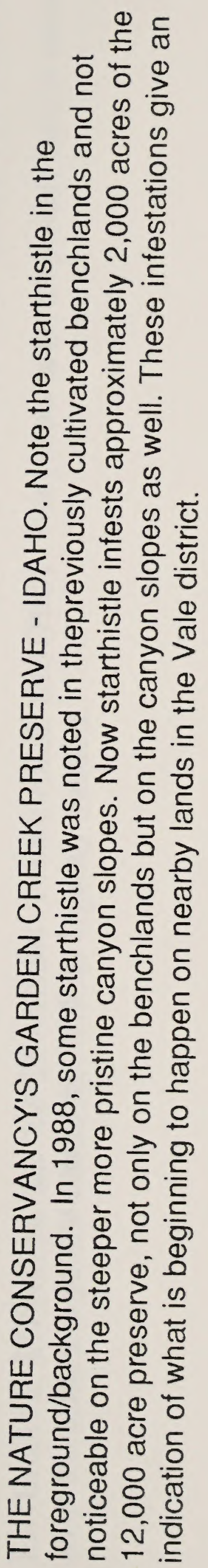





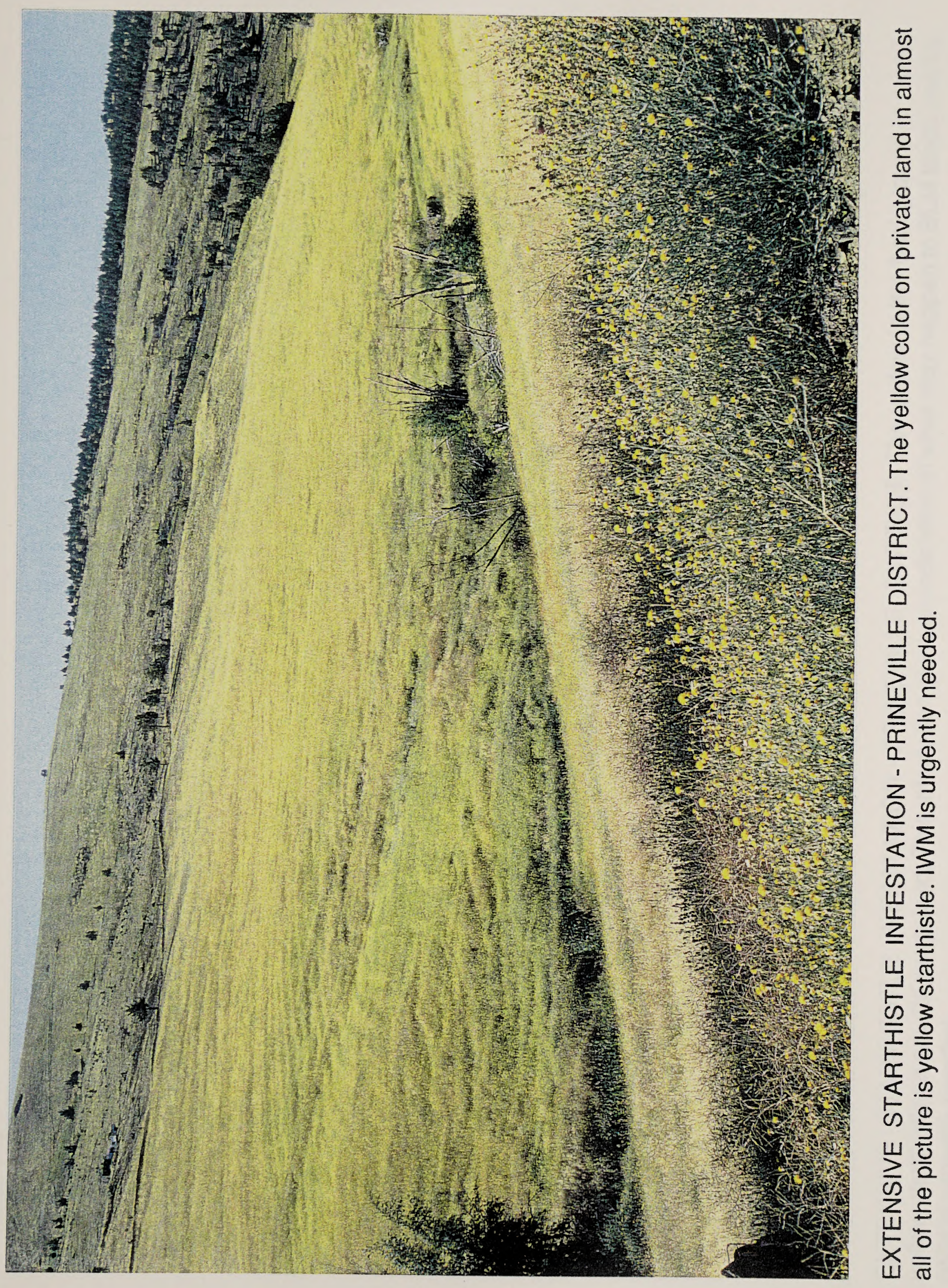





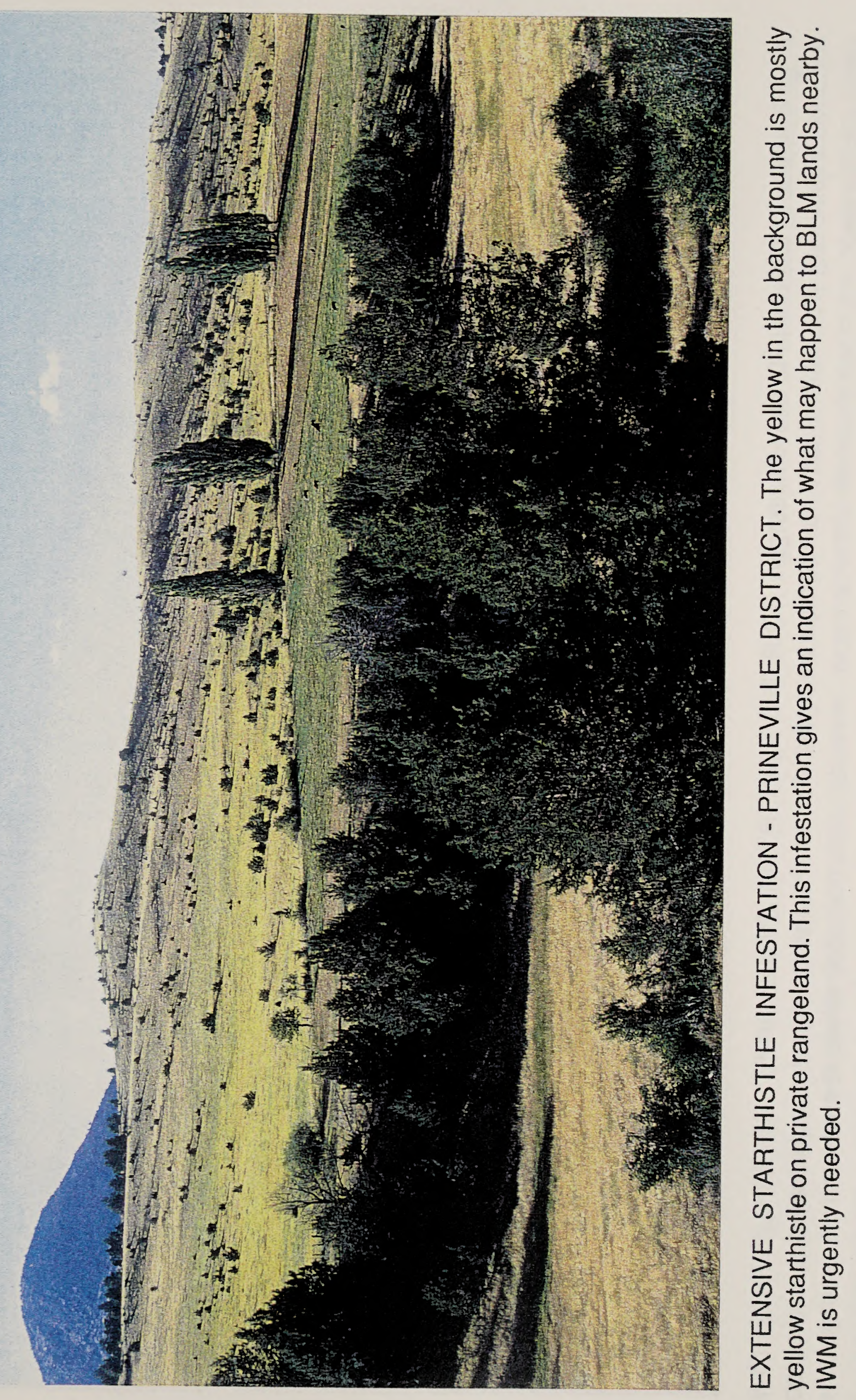




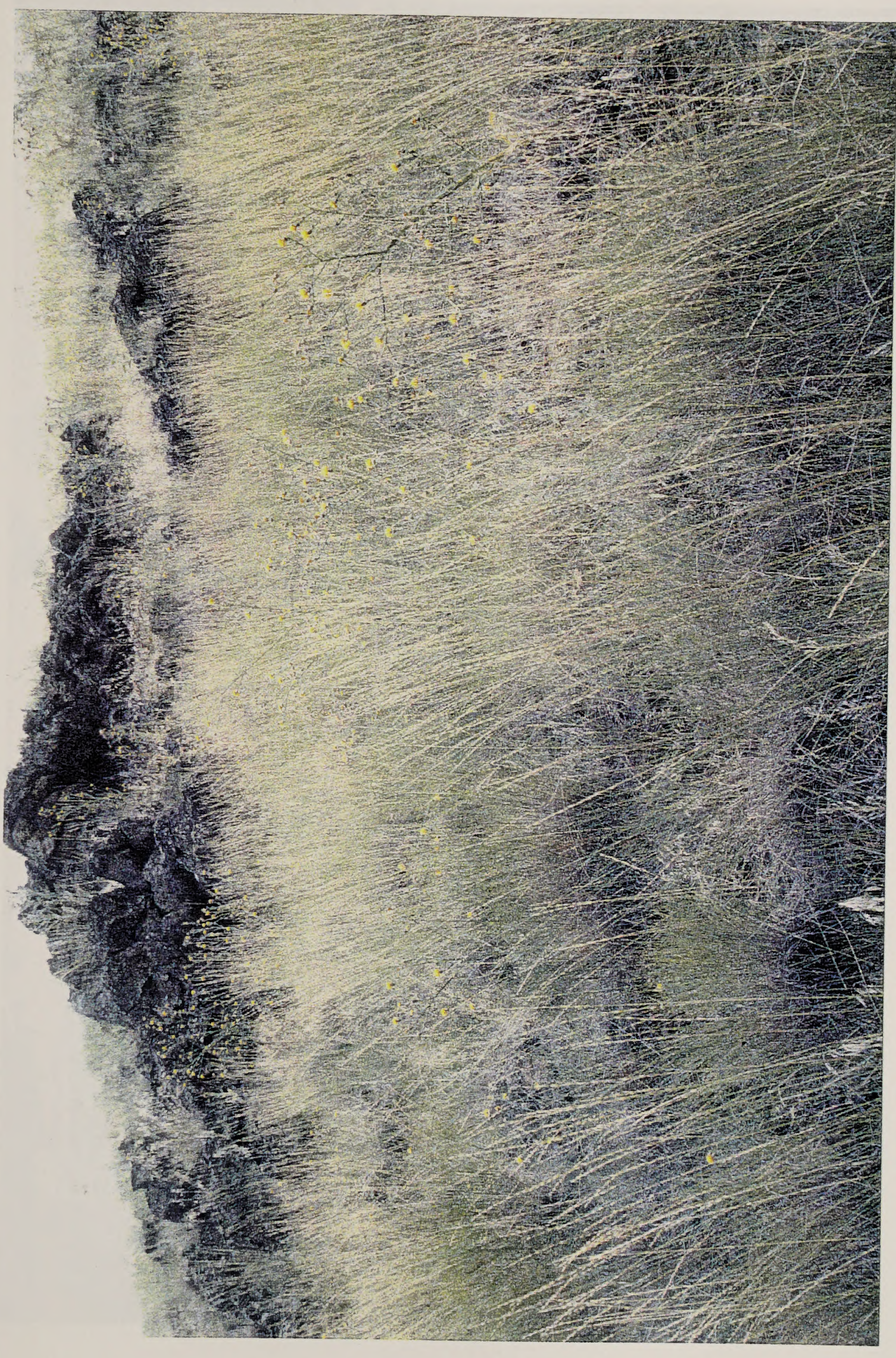

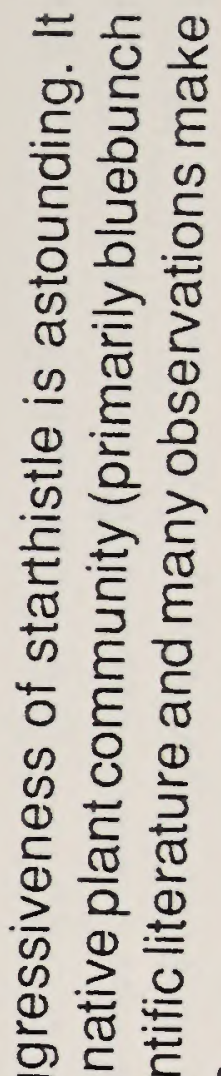

융 둥

$<8 \%$

는옥

U를

당 잉

क ऽ

○

世

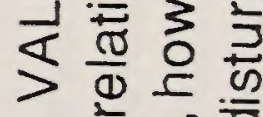

๙ँ

Ш

도잉

山 0 은

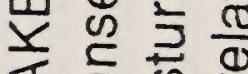

$\varangle \frac{0}{8}$

क ज

$\simeq \equiv \frac{1}{0}$

ㄸㅇ응

乙 ᄃ잉

1 응

Ш

융

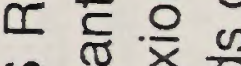

⿻ ⿷匚八

플

II क क

之

山थ

क 흥휴

Ш 



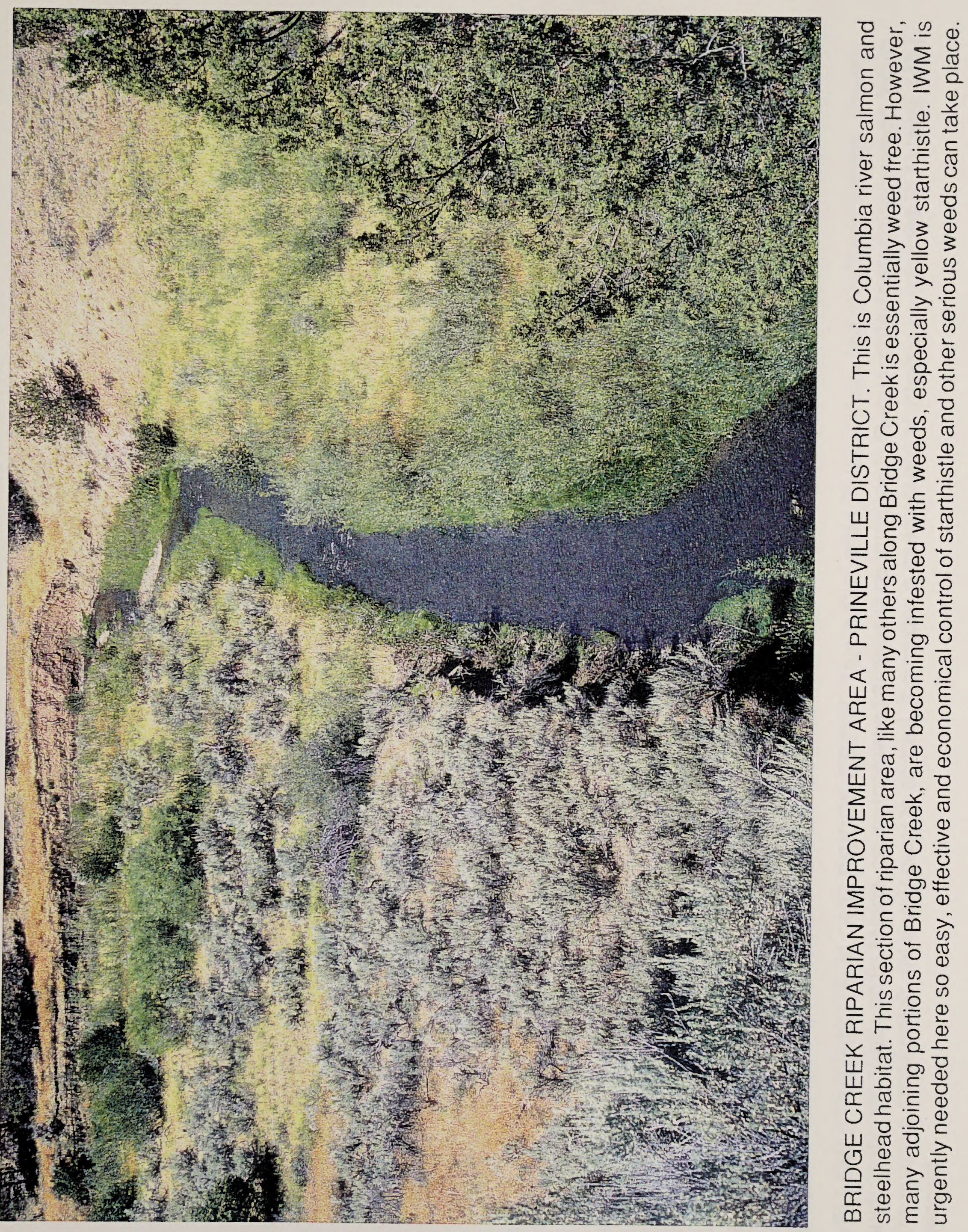





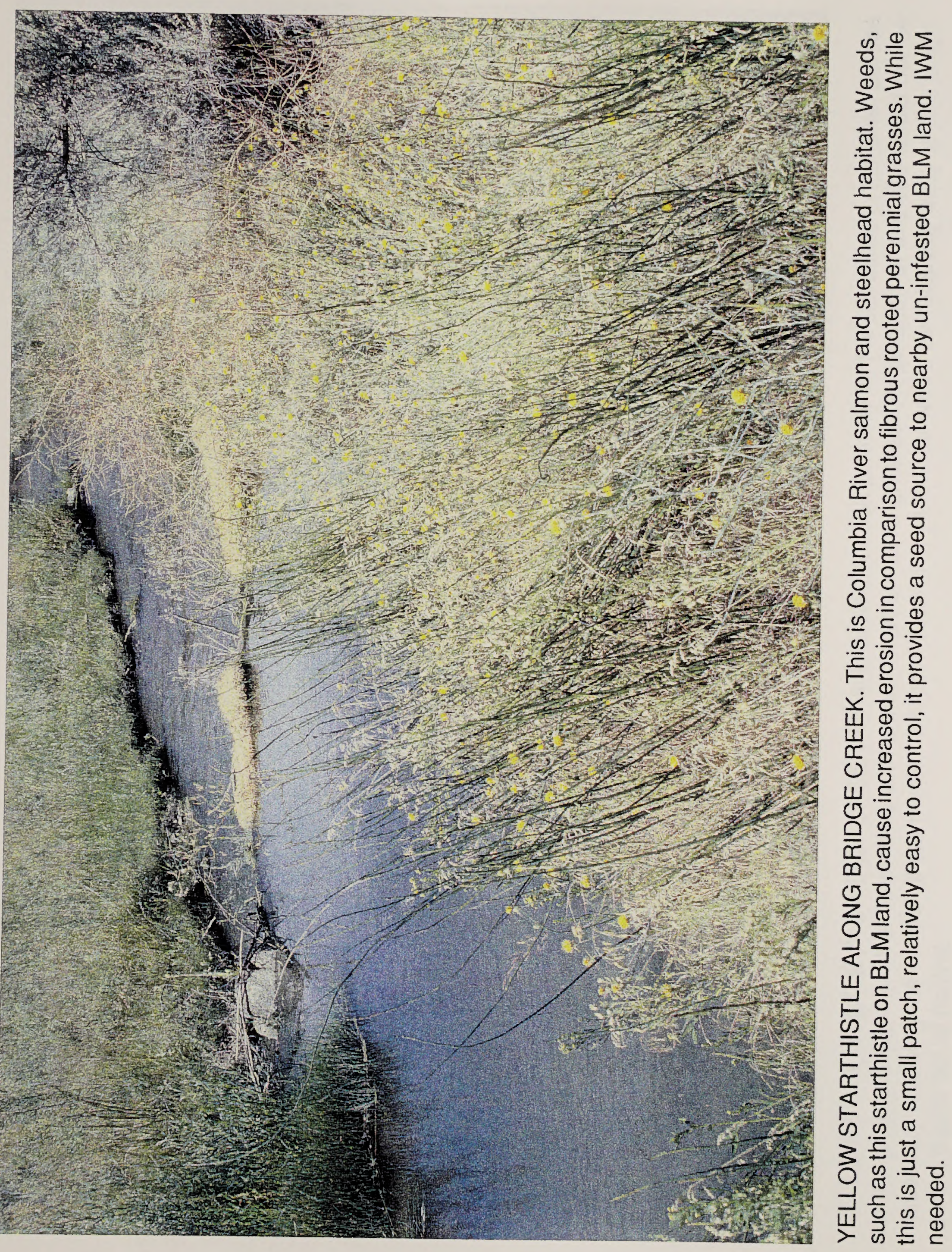





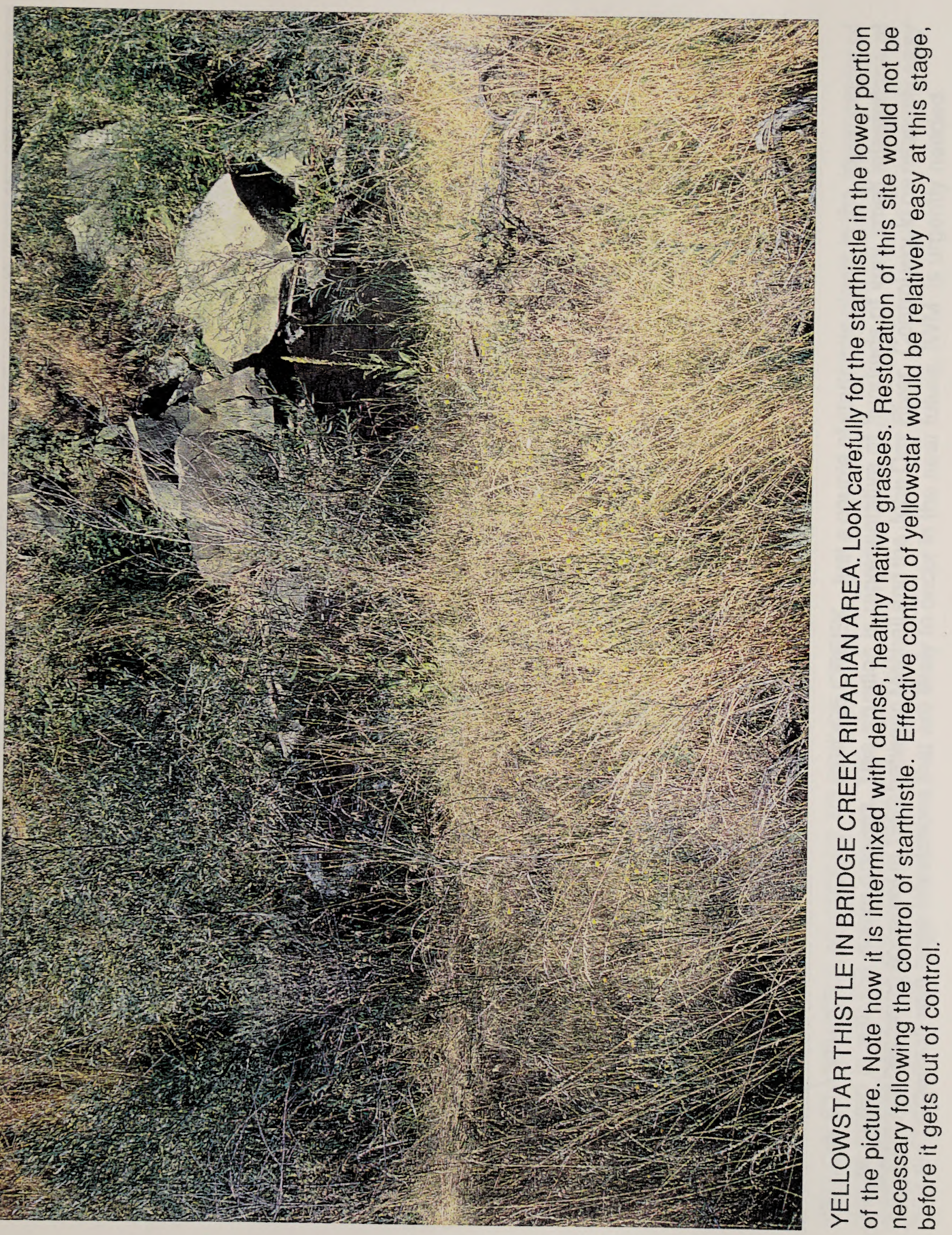





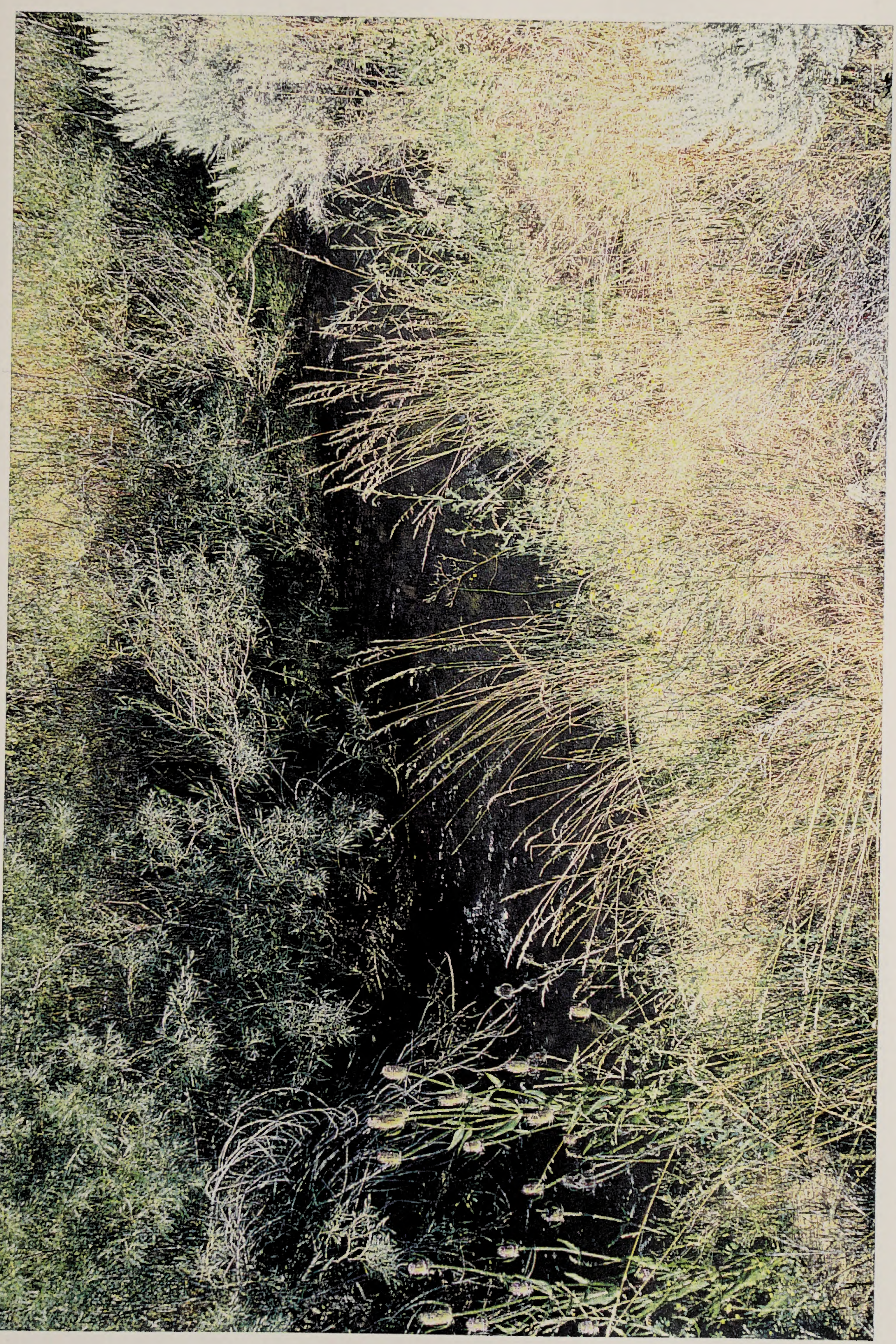

पั口 के पू

드음

ठ त व

के

$3 \stackrel{\frac{\pi}{0}}{0}$

ब $\overline{\overline{0}}$ 잉

$£$ E 등

$\subseteq$ ज $\frac{0}{5}$

क 200

莣 $\frac{1}{>} \frac{3}{0}$

造范要

品 可

잉

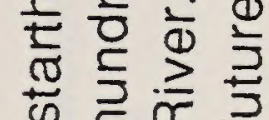

प닟

잉 0 (1)

응 통

어웡응

(ब) बक 0

क ल $\cong$

3 응

ब ब

㟧 $\overline{\bar{\alpha}}$ 응

Wᄃ

뚜웜

0 焉

山

ए $\frac{2}{\omega} \frac{1}{\omega}$

の

里足

品票

0 ले

$\vdash$ \%

$\vdash$ क

$\sum \sqrt{2} \subseteq \frac{\pi}{4}$

पढ口

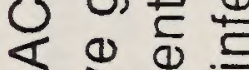

就

ช 은

11 으

녿 을

心志产

严

F

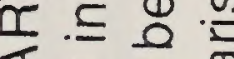

एक क क

ज

3 E्

O $\frac{\omega}{0}$

马ั

出 $\frac{0}{0} \frac{0}{0}$ 



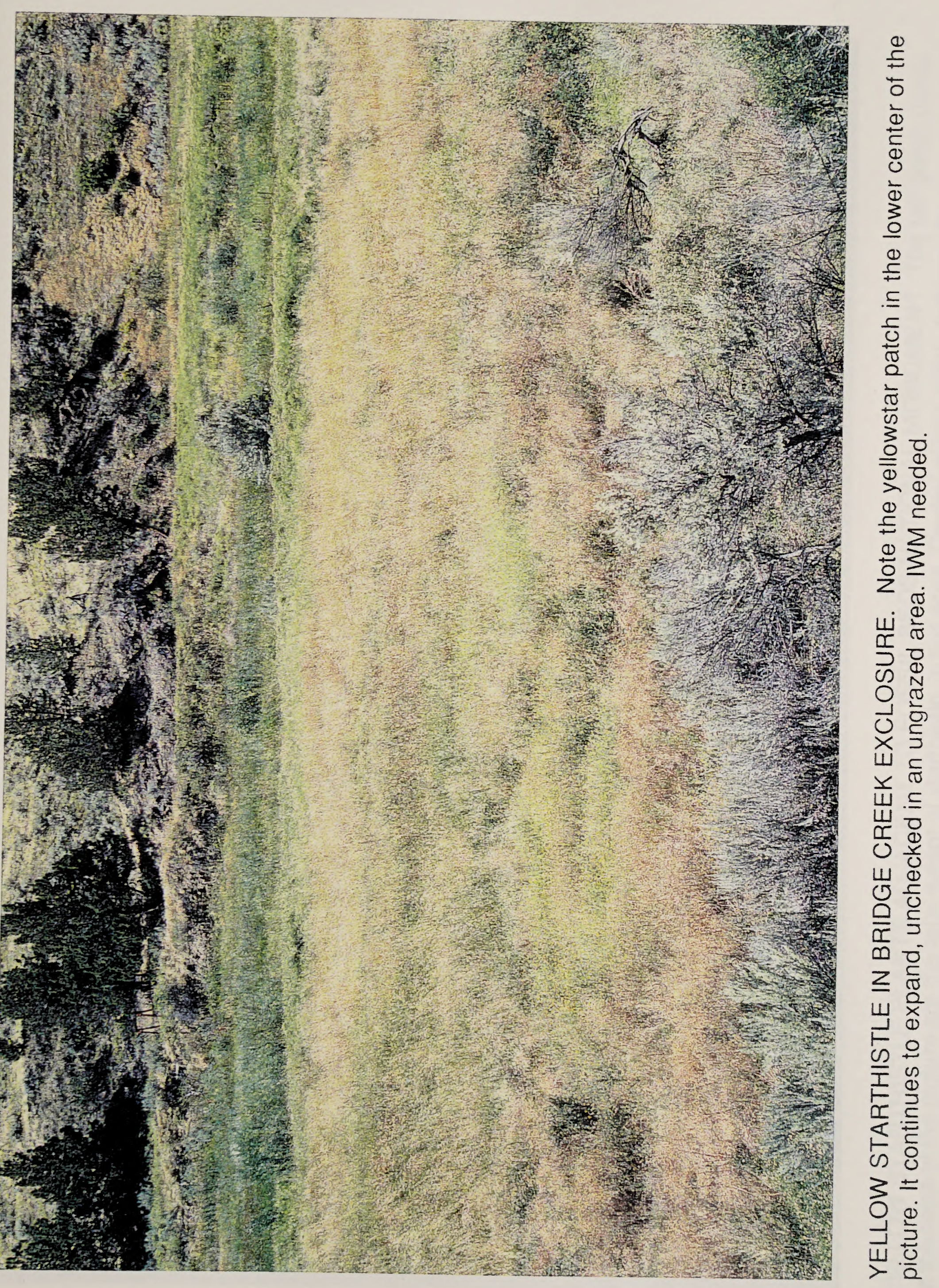





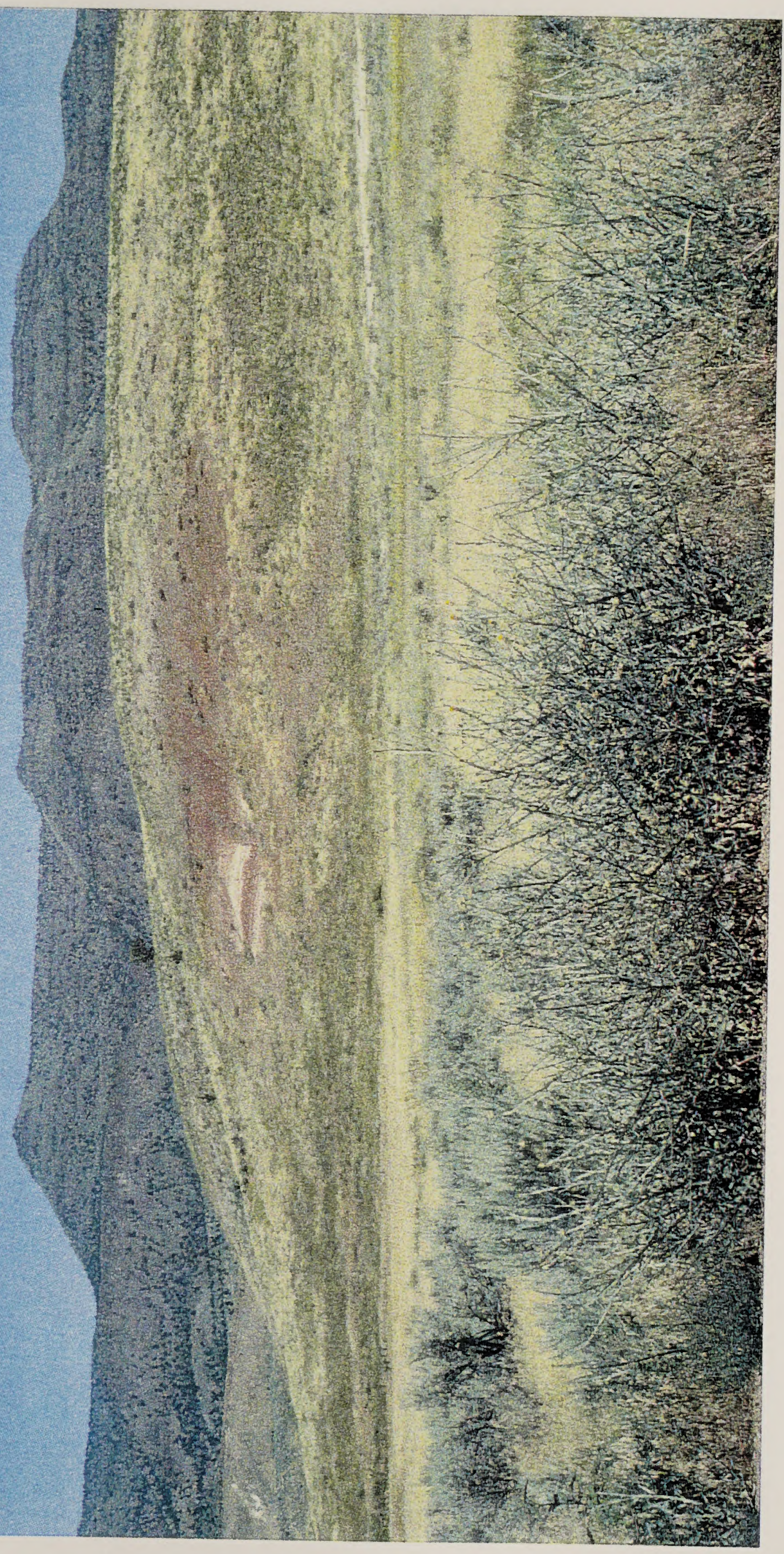

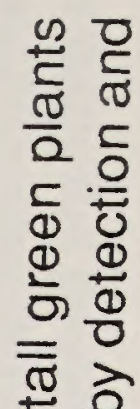

(ब)

F

占응

एᄃㅜㅇ

引

의 $\cong$

2 든

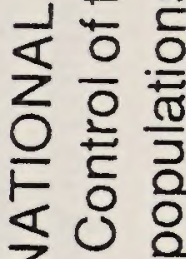

$z$

๙

సั

$m$ n

$\perp$ 잉

क ज

至

을

1 药

之施

$0 \pm$

$\$ \Phi$

๑

$<\frac{0}{\pi}$

M

过

舟

สั

Ш

Q

王 $\frac{0}{2}$ 응

产乒 은

눙잉

( ) 0

3 क ष

0 ○

岃导 



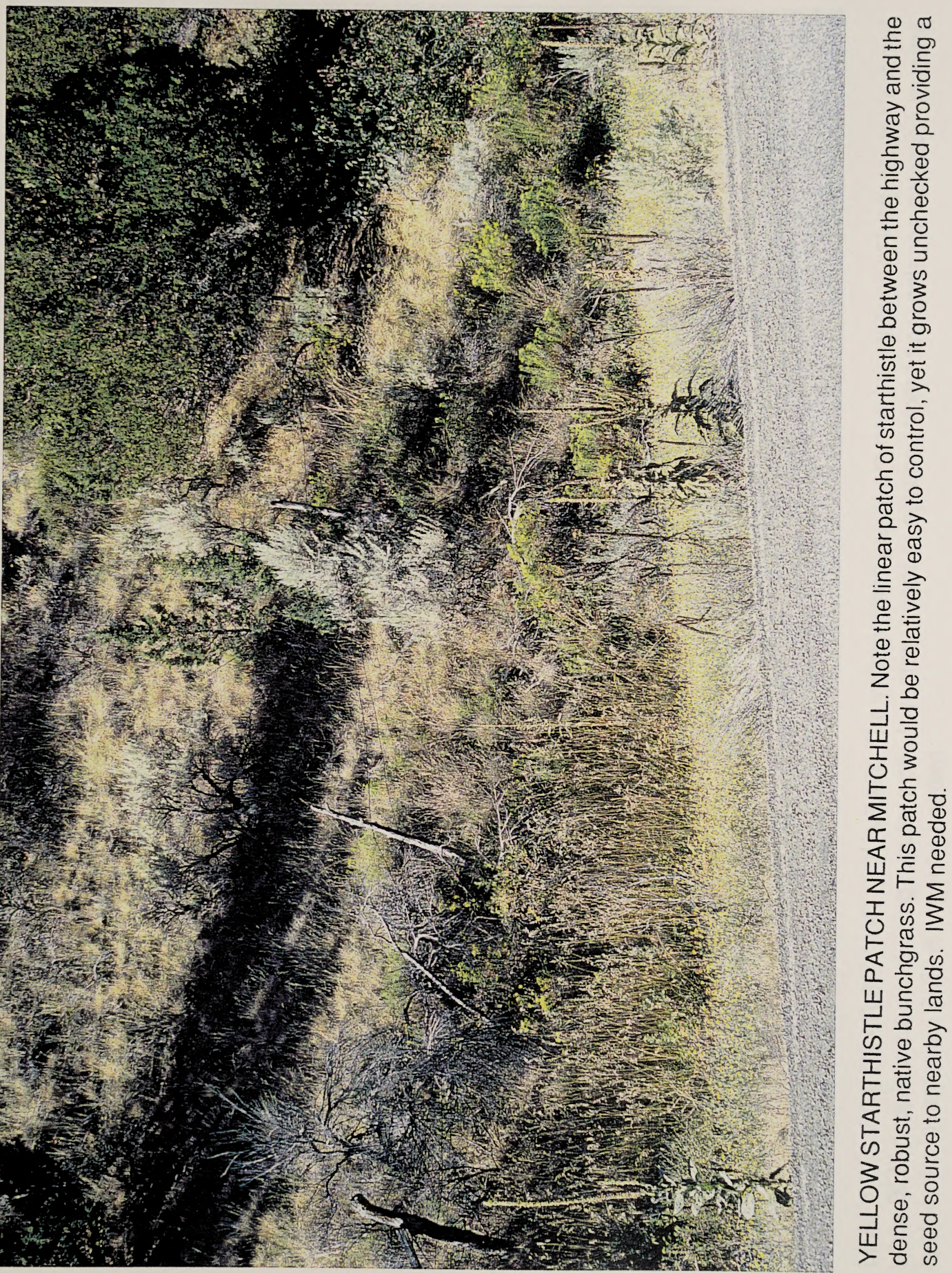





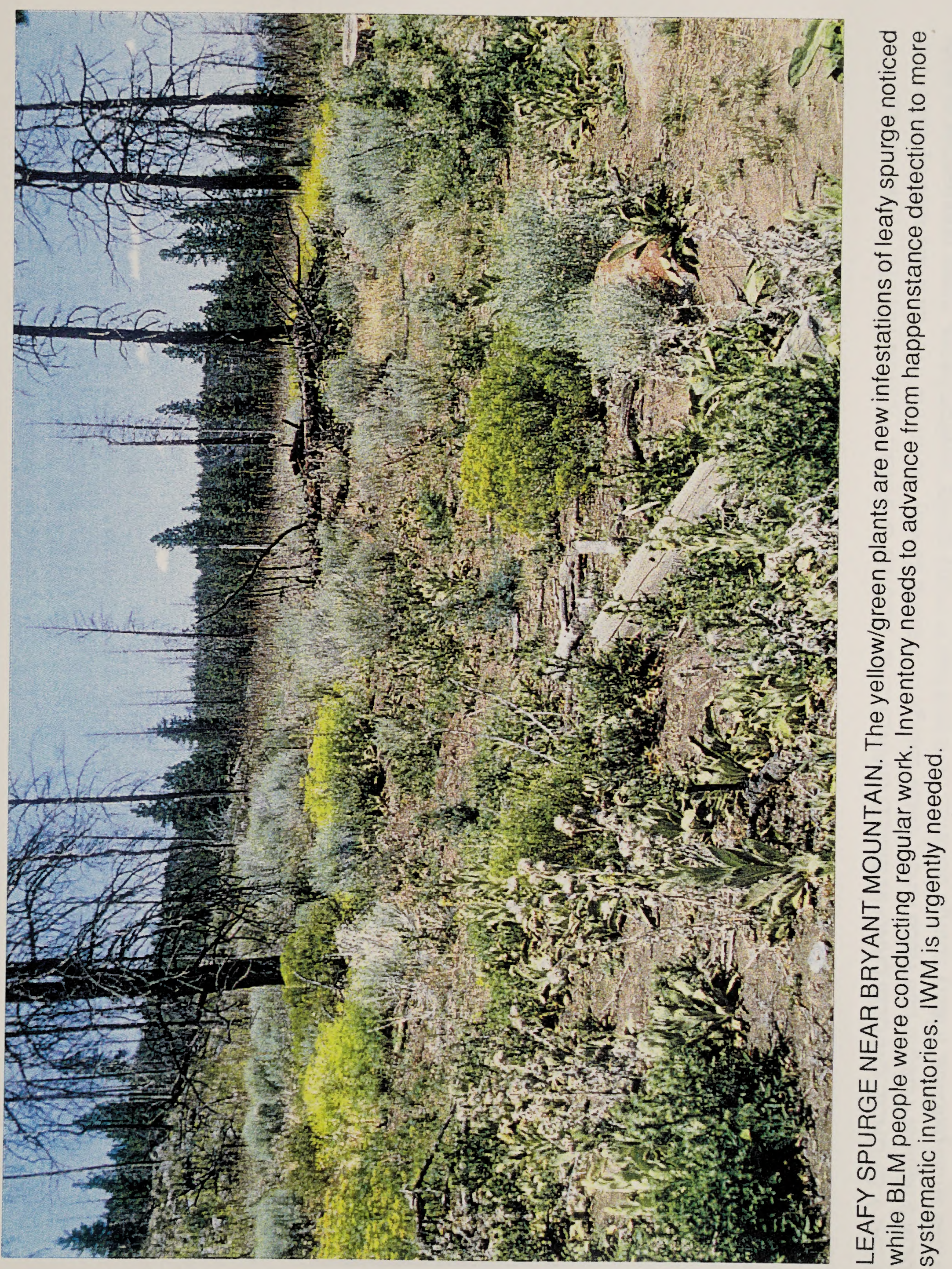




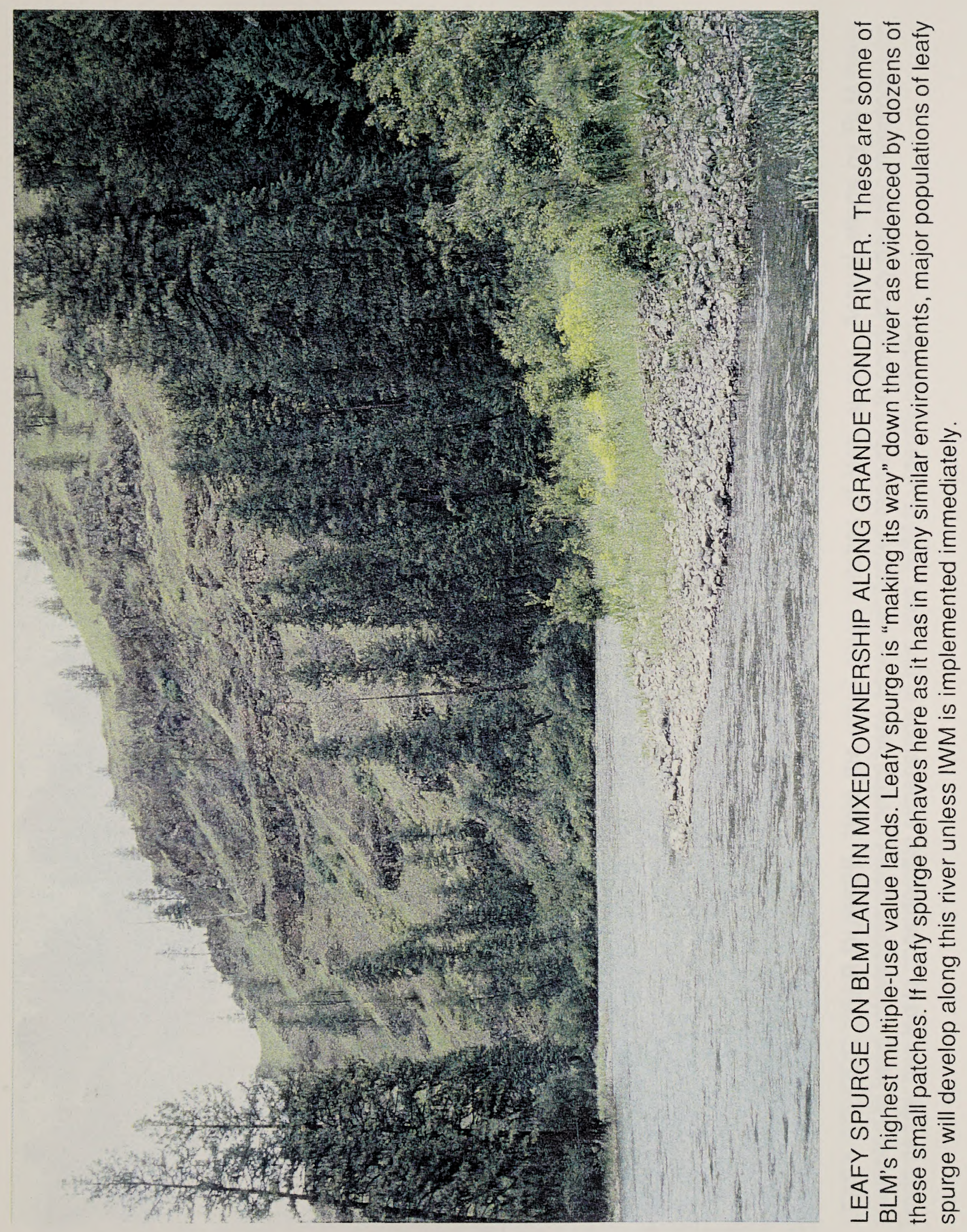



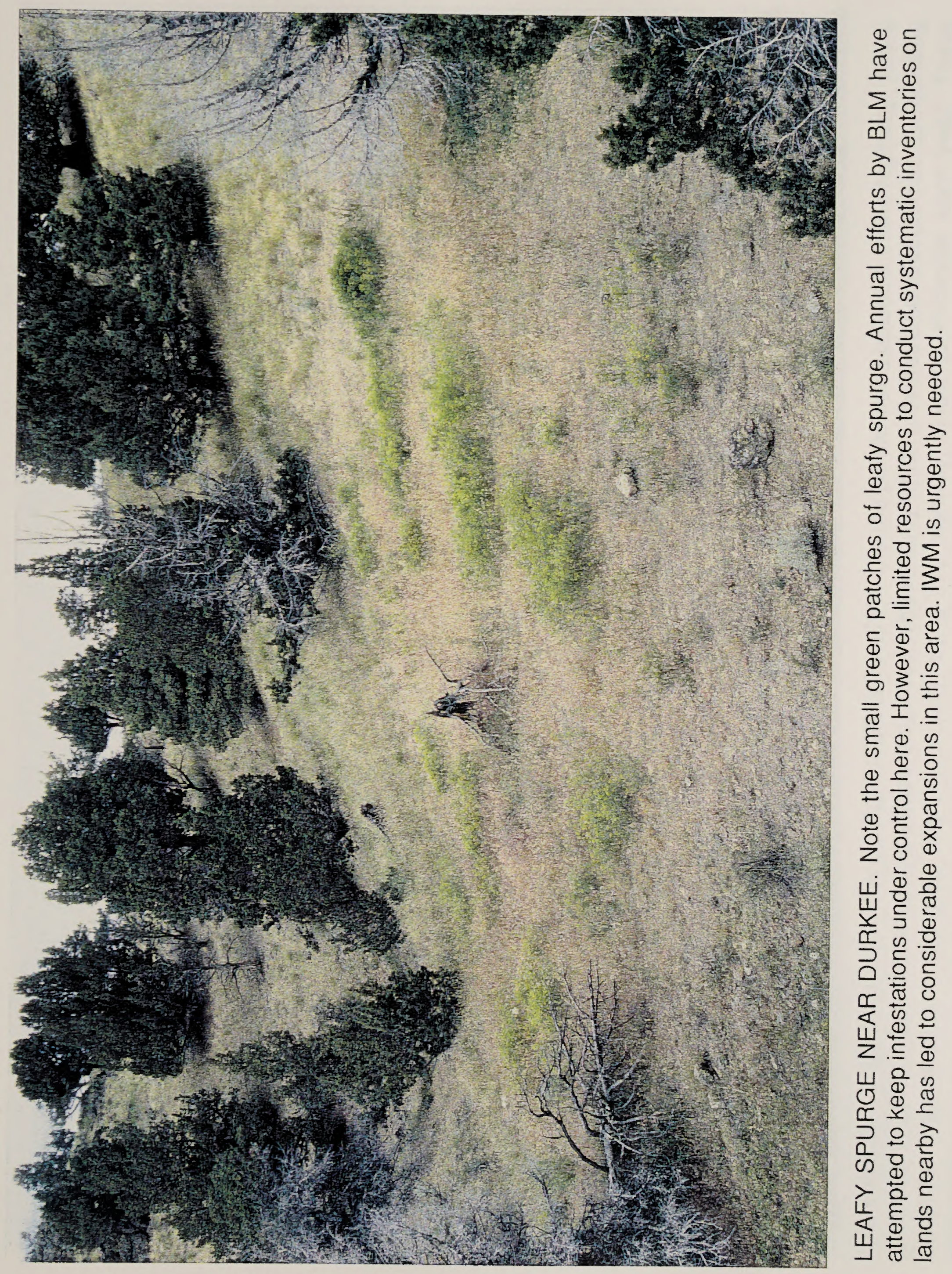




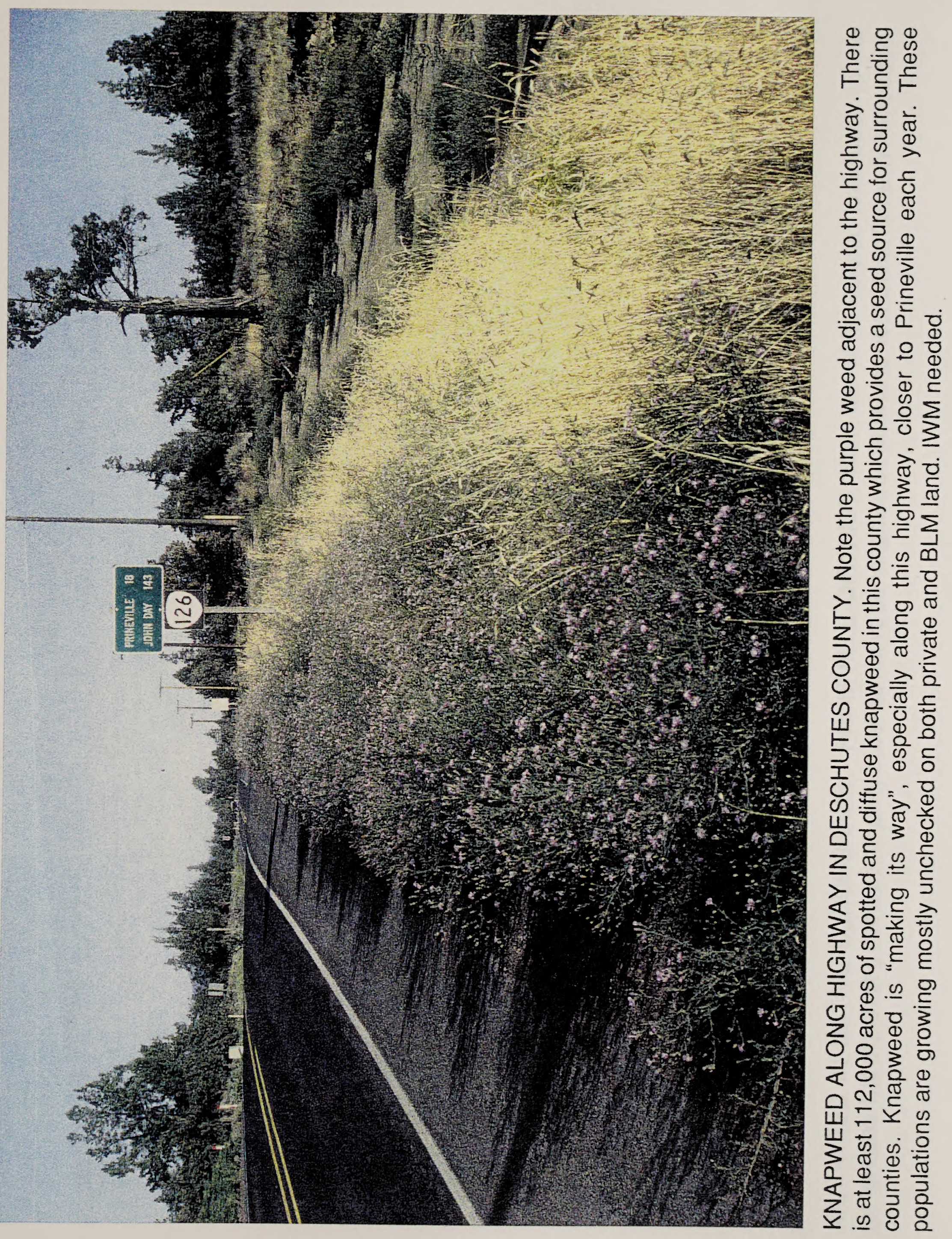




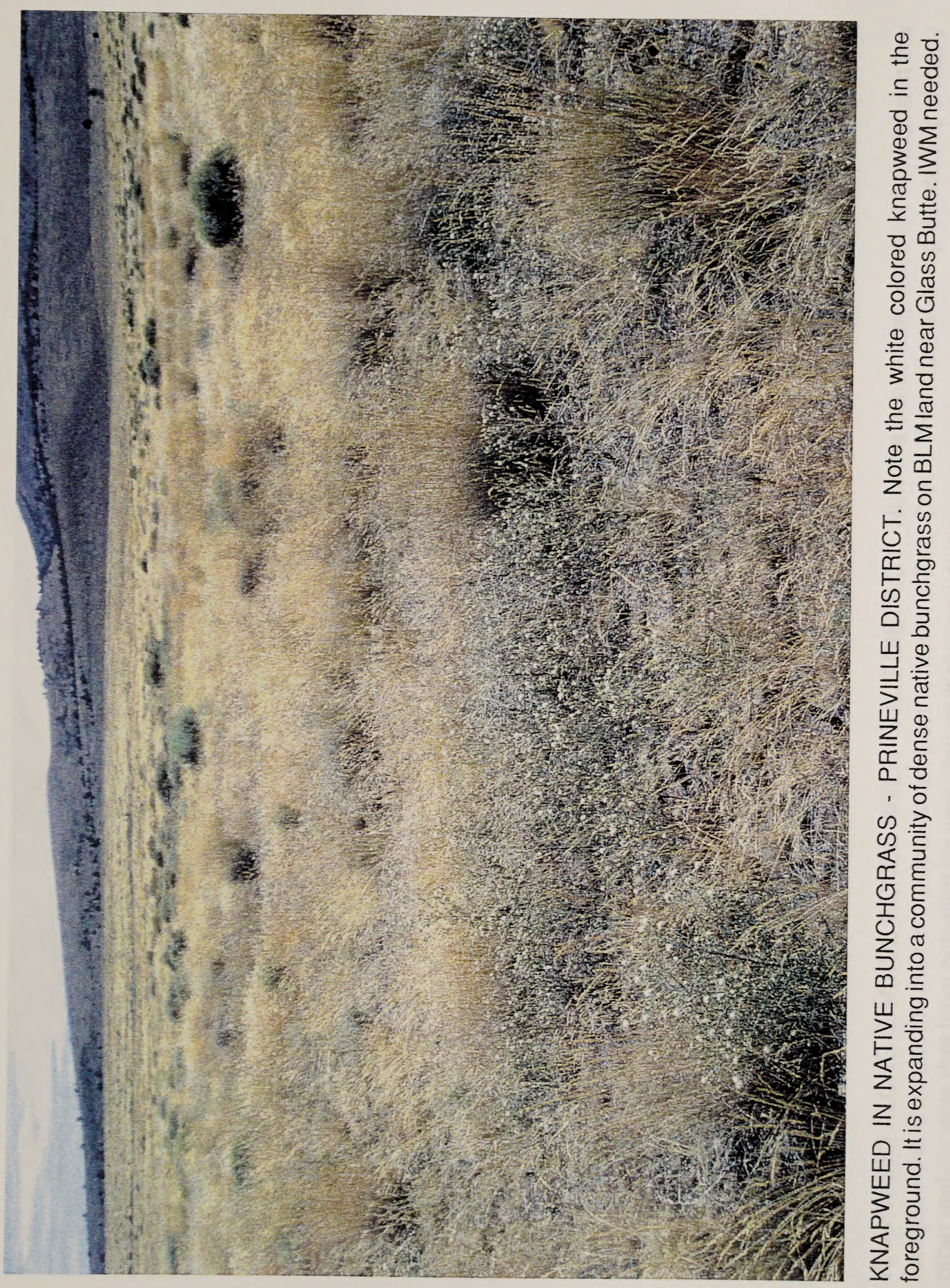




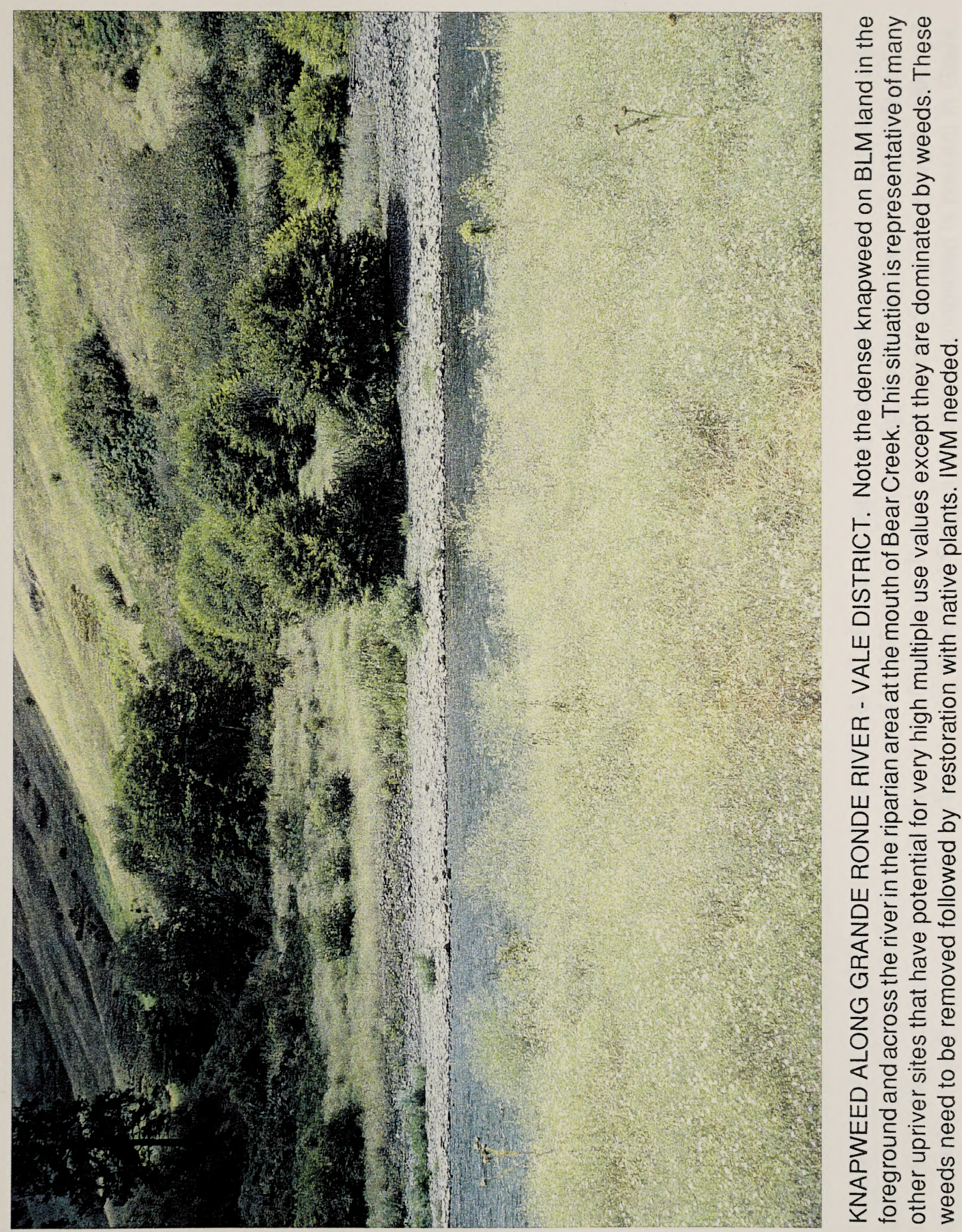



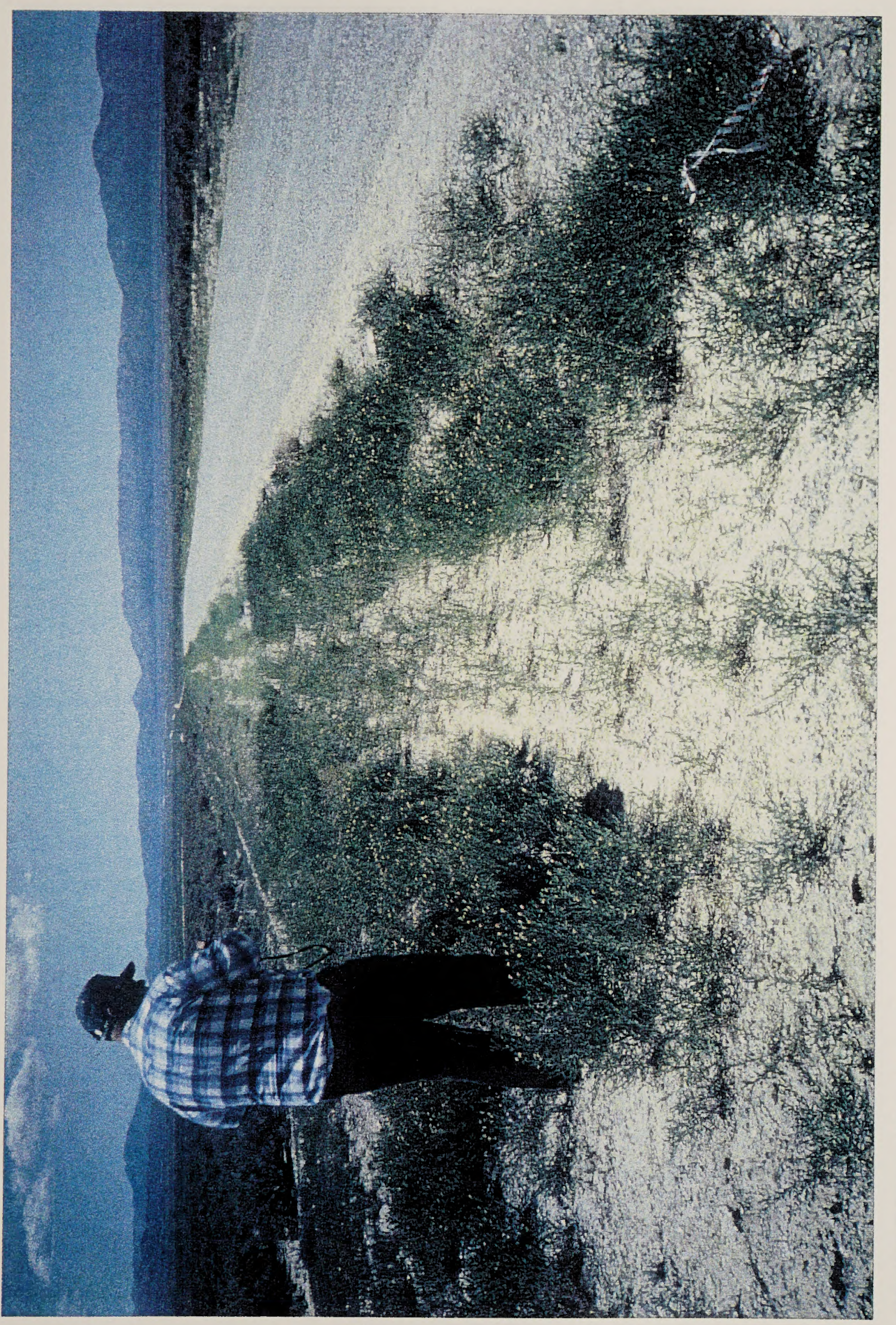

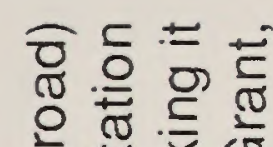

임 需

+ 을

它

0

뭉 인 인

ชั $\frac{\pi}{0}$ क

을 으

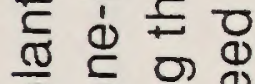

등이

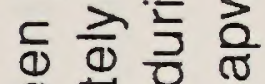

인 훙

으 हᄐ 당

응 요

d 는

3 은 0 힌

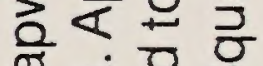

ธ్ర

ฟ $\frac{1}{2}$

北

잉ㅇㅇ

ธิ. \pm 0

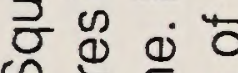

๙ 등

I

용ㄷㅇ

50 응

Z

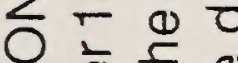

$\checkmark>$

$\sum$ 웡

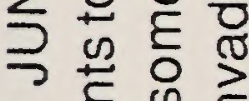

은 음

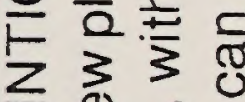

$\leq \Psi 00$

- ๙

อ ํํㅇํํำ

펜ㄷㅇ 응

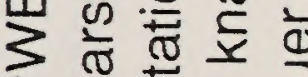

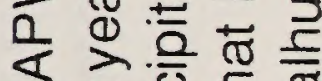

之记

$x$ ¿

山

$0 . \subseteq$.

व

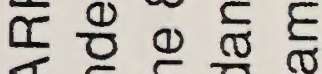

ऽ

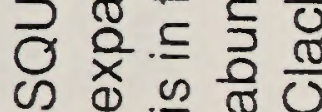





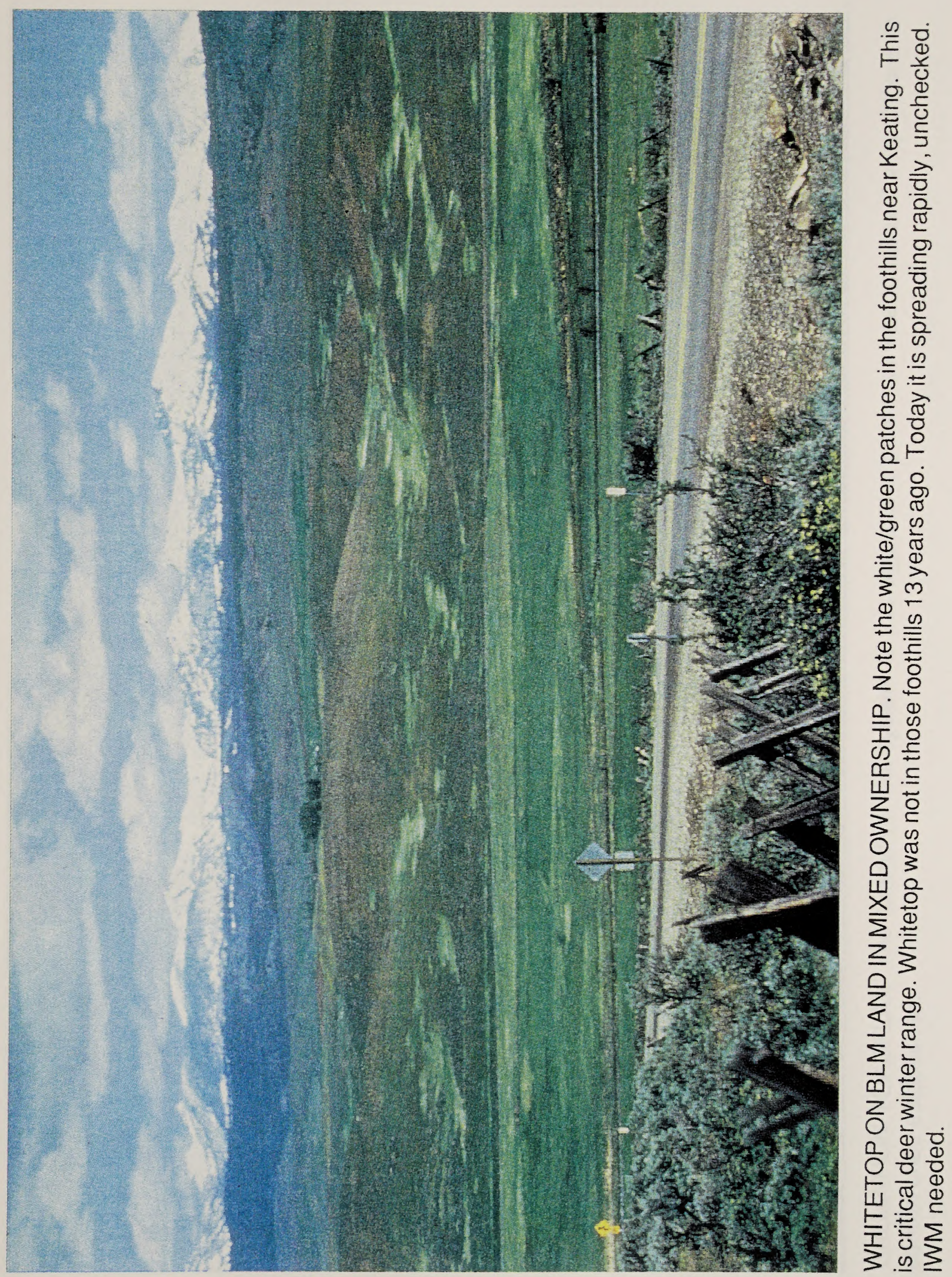




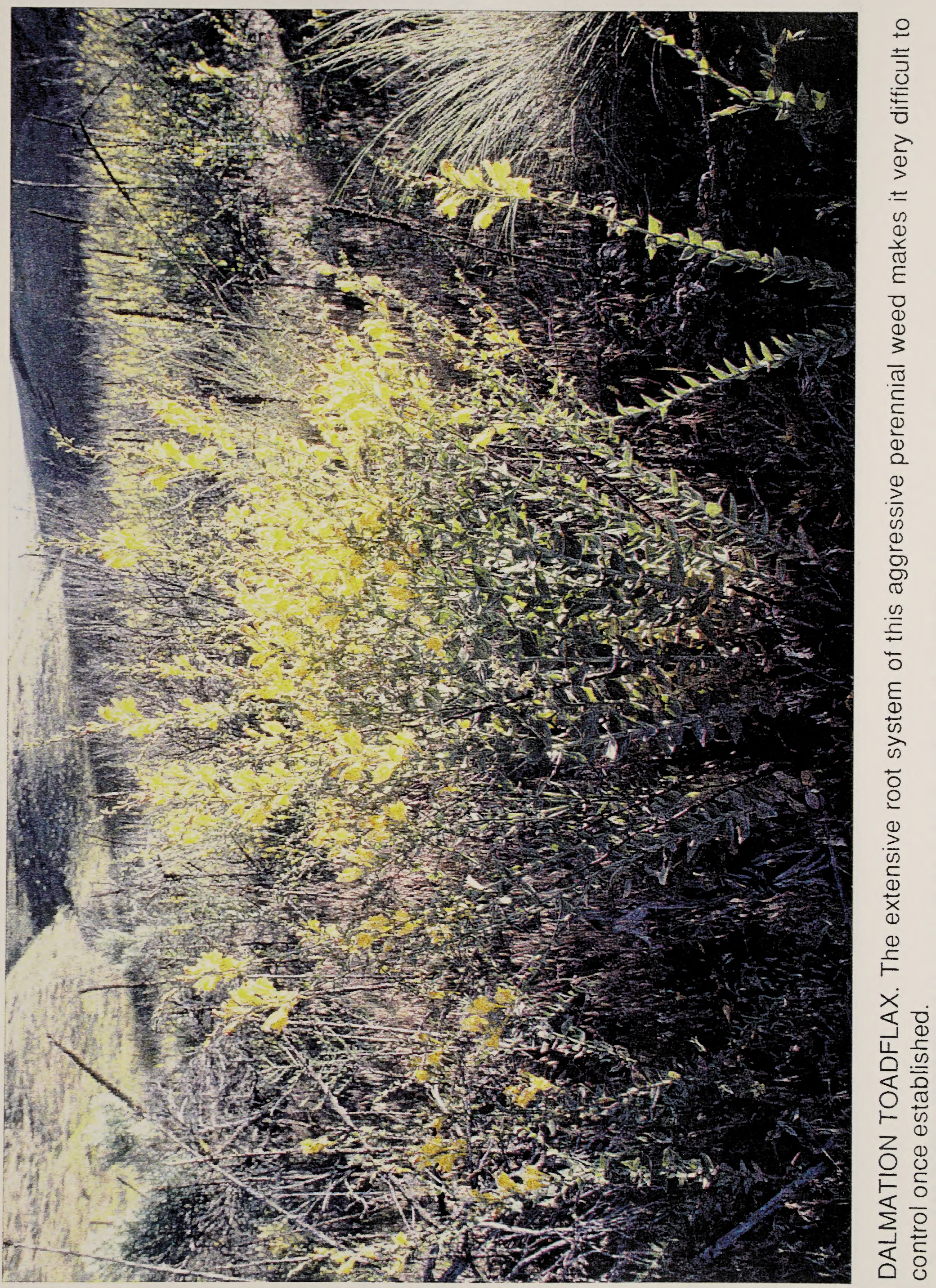





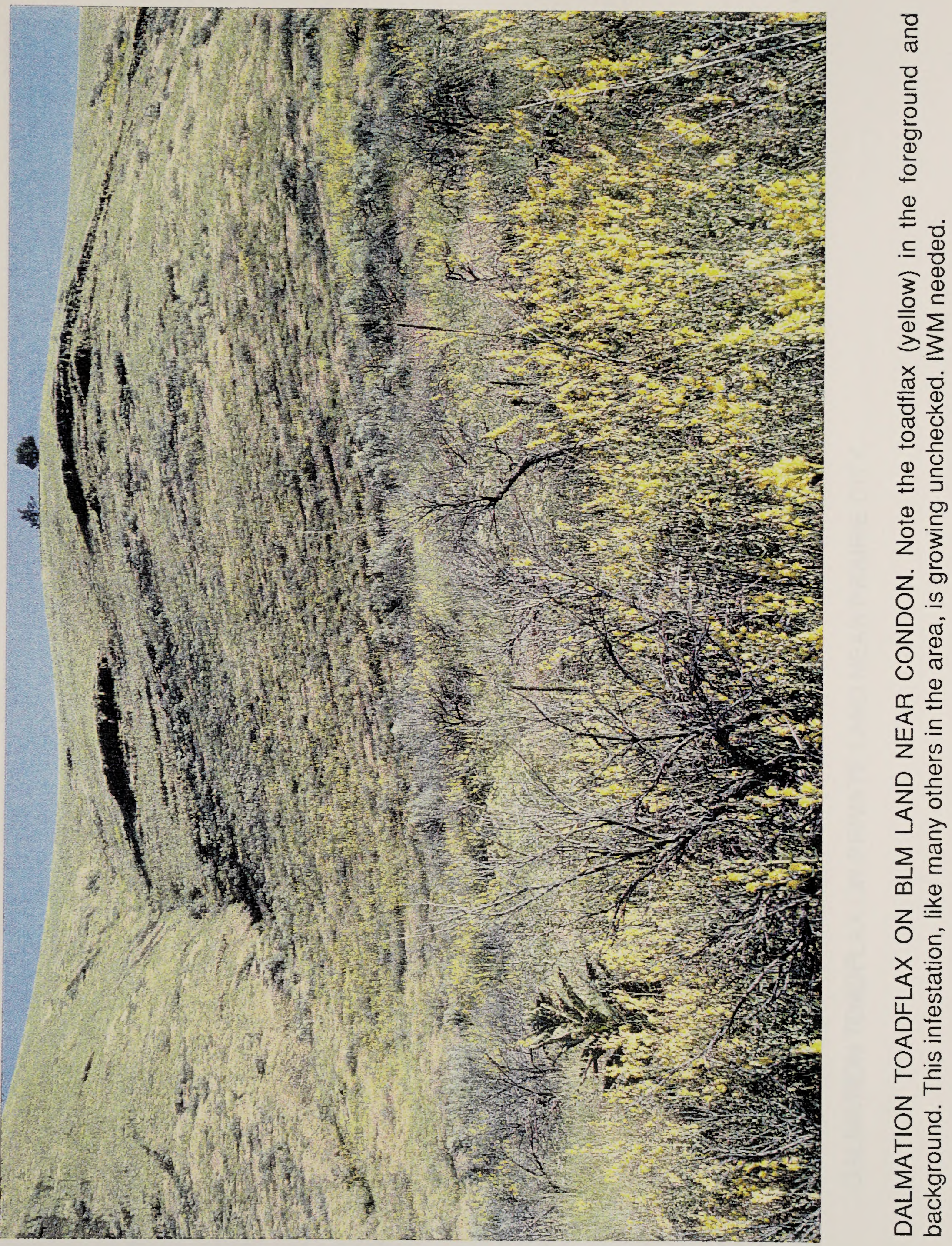





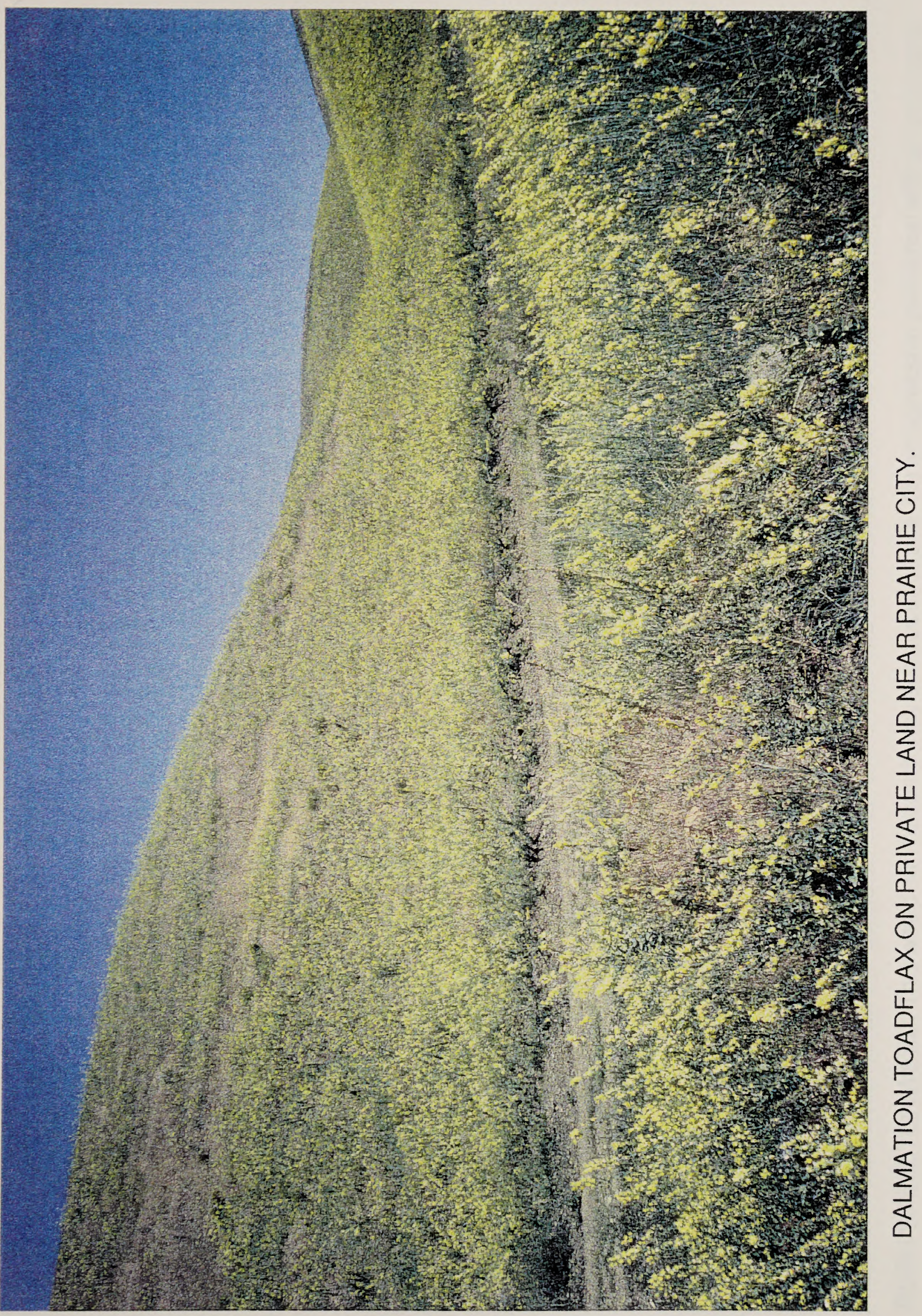




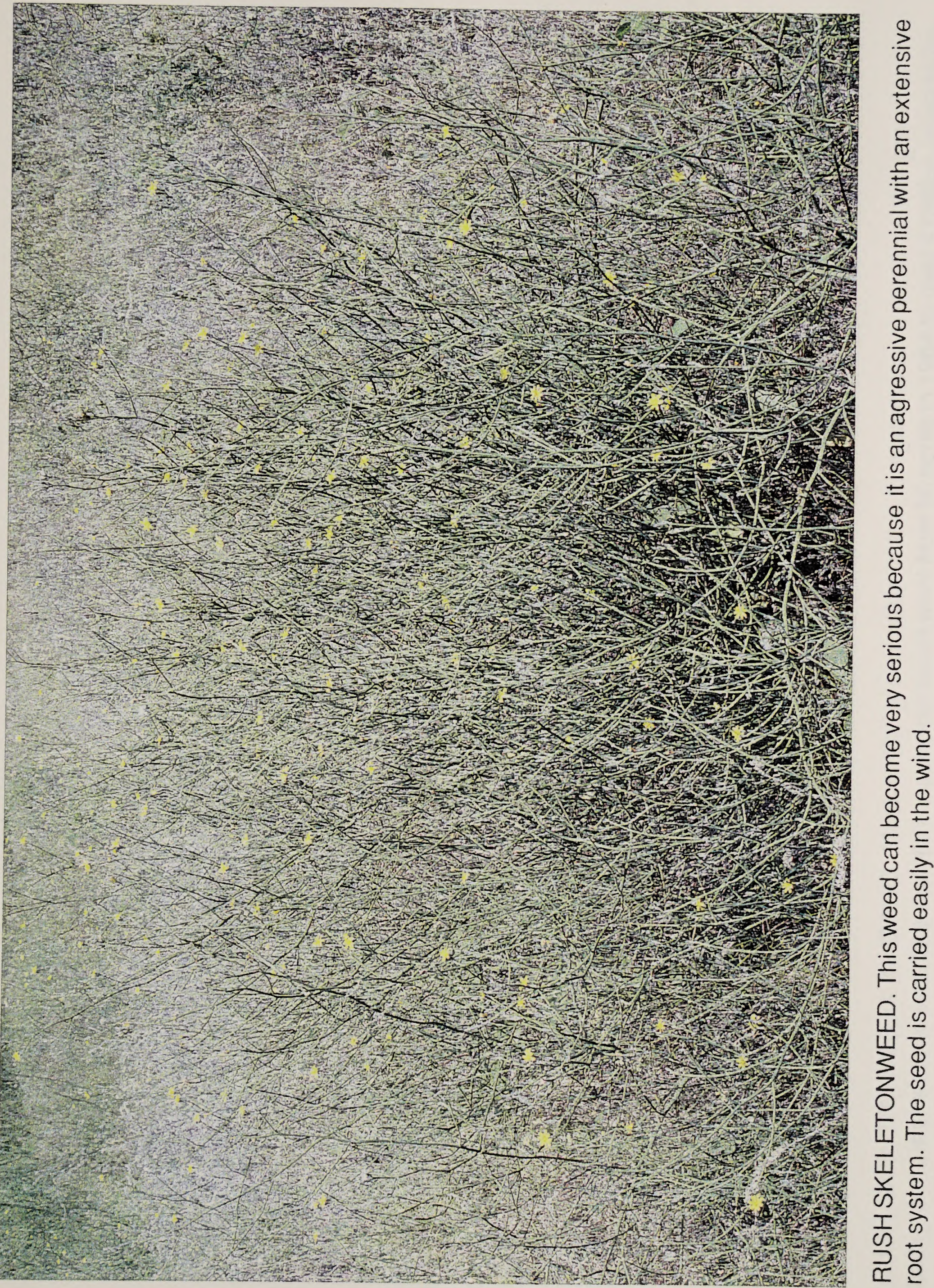





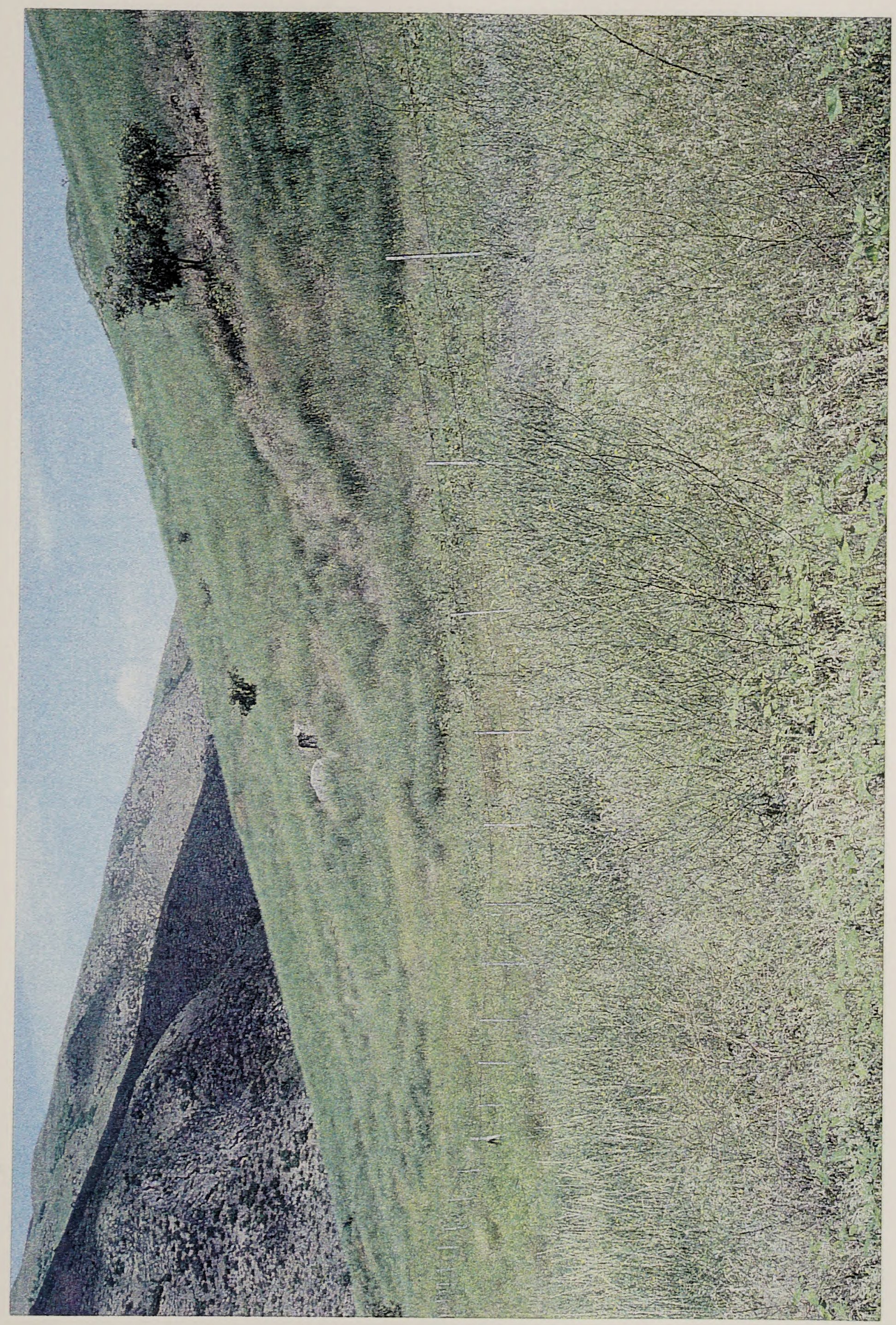

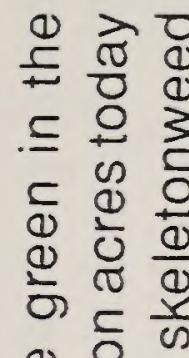

등 을

$\leftleftarrows \overline{\bar{E}} Q$

(1) $\div \frac{0}{0}$

है ऐ

i 0 O

응

ब

윽드웜

잉

万)

ब

으늠

() ह ब

$\therefore$ 은

$= \pm$ ర্

응

용

도을 을

(1)

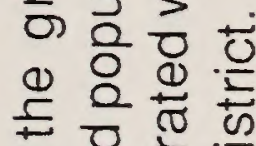

ธ。

$\div 3 \stackrel{0}{5} \frac{\Phi}{\sigma}$

은 둥ㄱ

$\sum$ 웡

우 호 일

एक ल

巳

$\leq \dot{0} . \subseteq 5$

웡

닐 음

3 드응응

$\sum$ 을 응

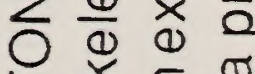

站

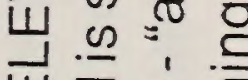

ш흐을

के ड़ 웡

든흐 옹

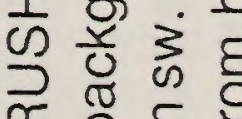





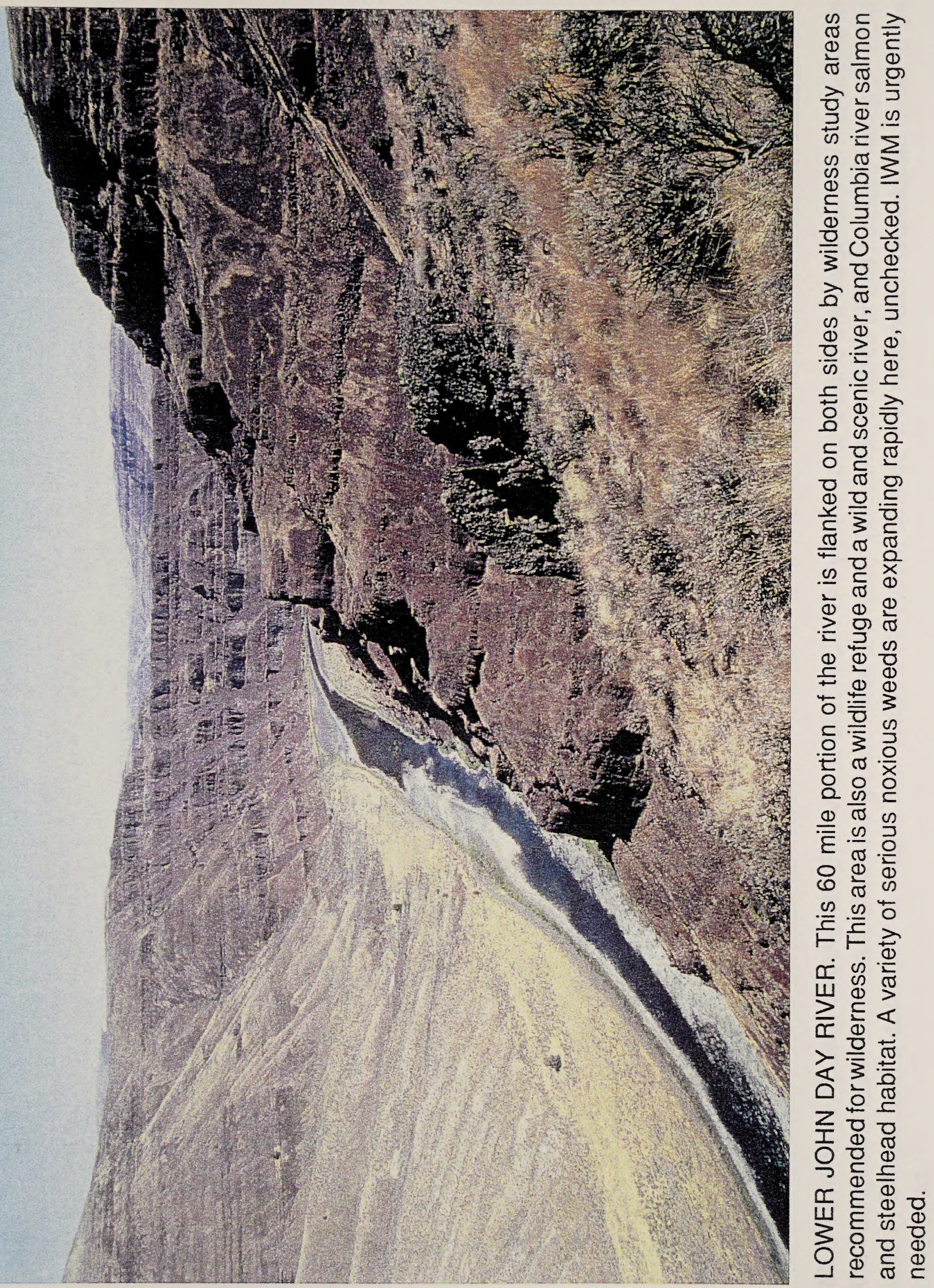





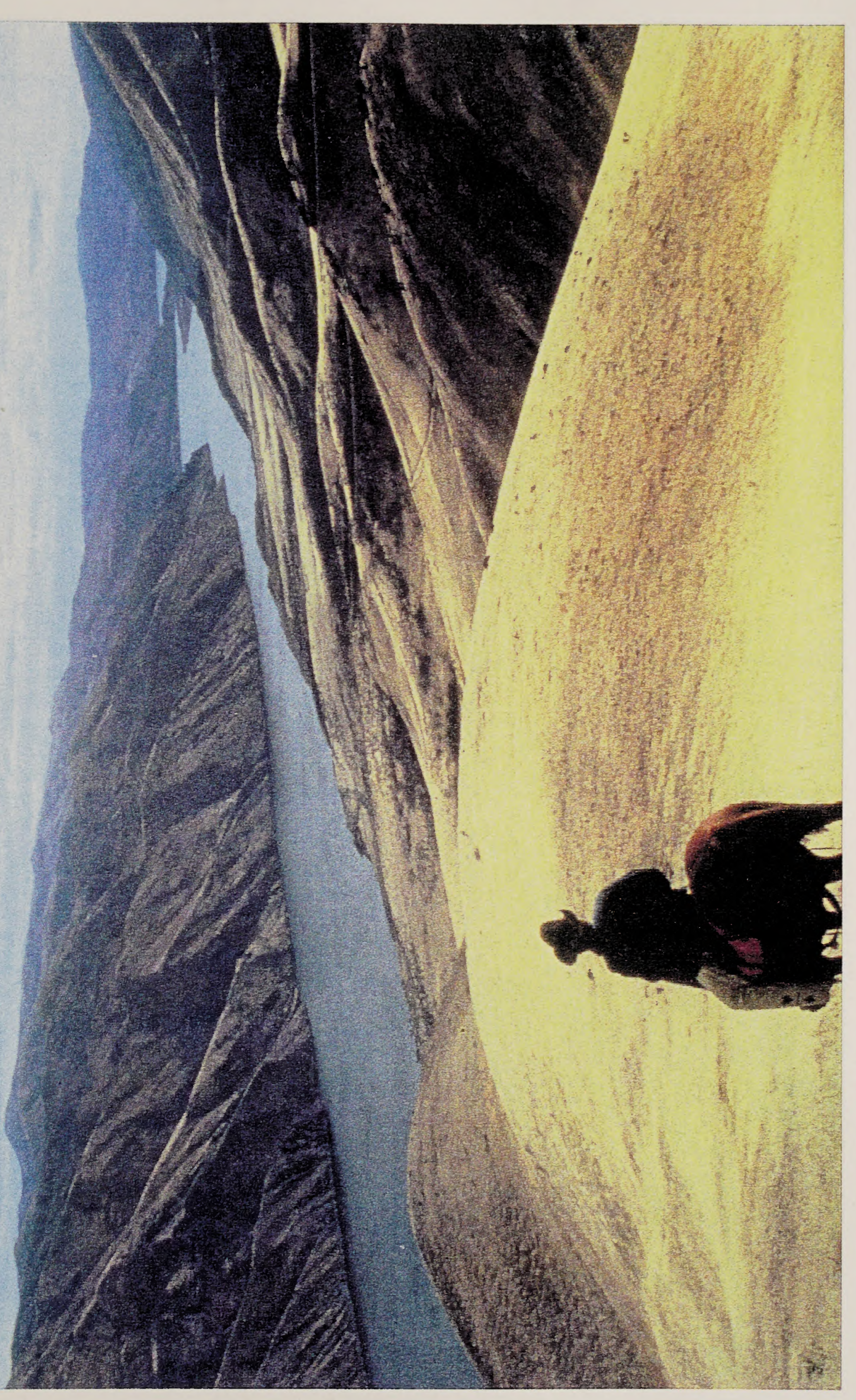

$\subseteq \Sigma \unrhd$

\&

은 등응

Ф 웜

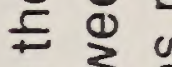

ㄷํㅇ

든 $\frac{0}{x} \frac{0}{5}$

$\Phi \stackrel{0}{\complement}$

호을

(4)

항 융

ริ ฮ

훙으

흥 융

O

응ㅇㅇㅇ

$>$ वं

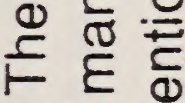

เัญ す

음

舟

正离

山

这芯焉

1

Ш

뜨 등ㅇ

山

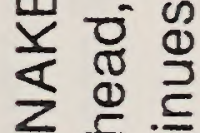

क 品

용

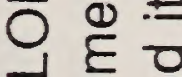

<.

\&등

넝 잉

宅

๑) 이드응

응

㞫昰宣。 


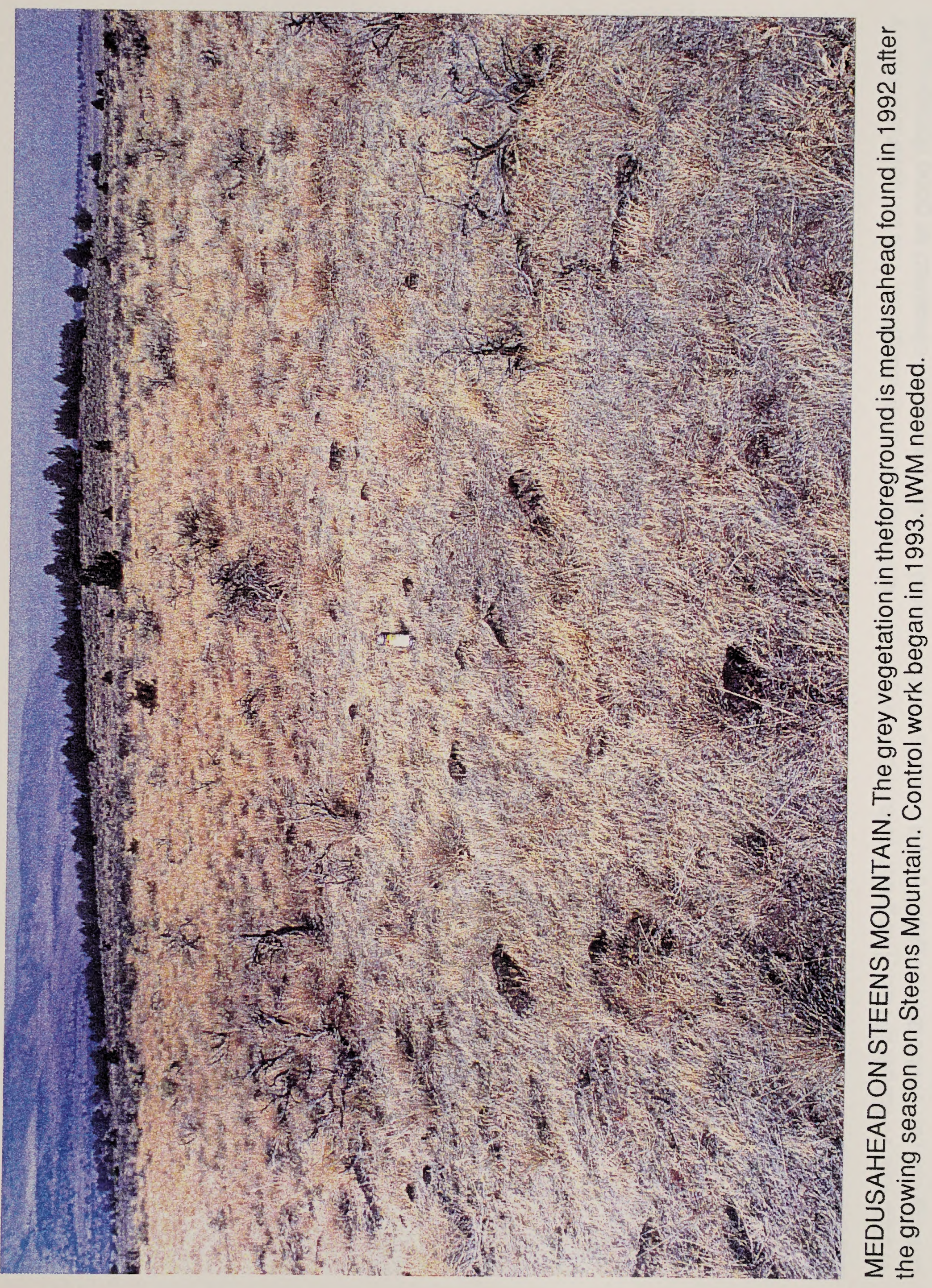




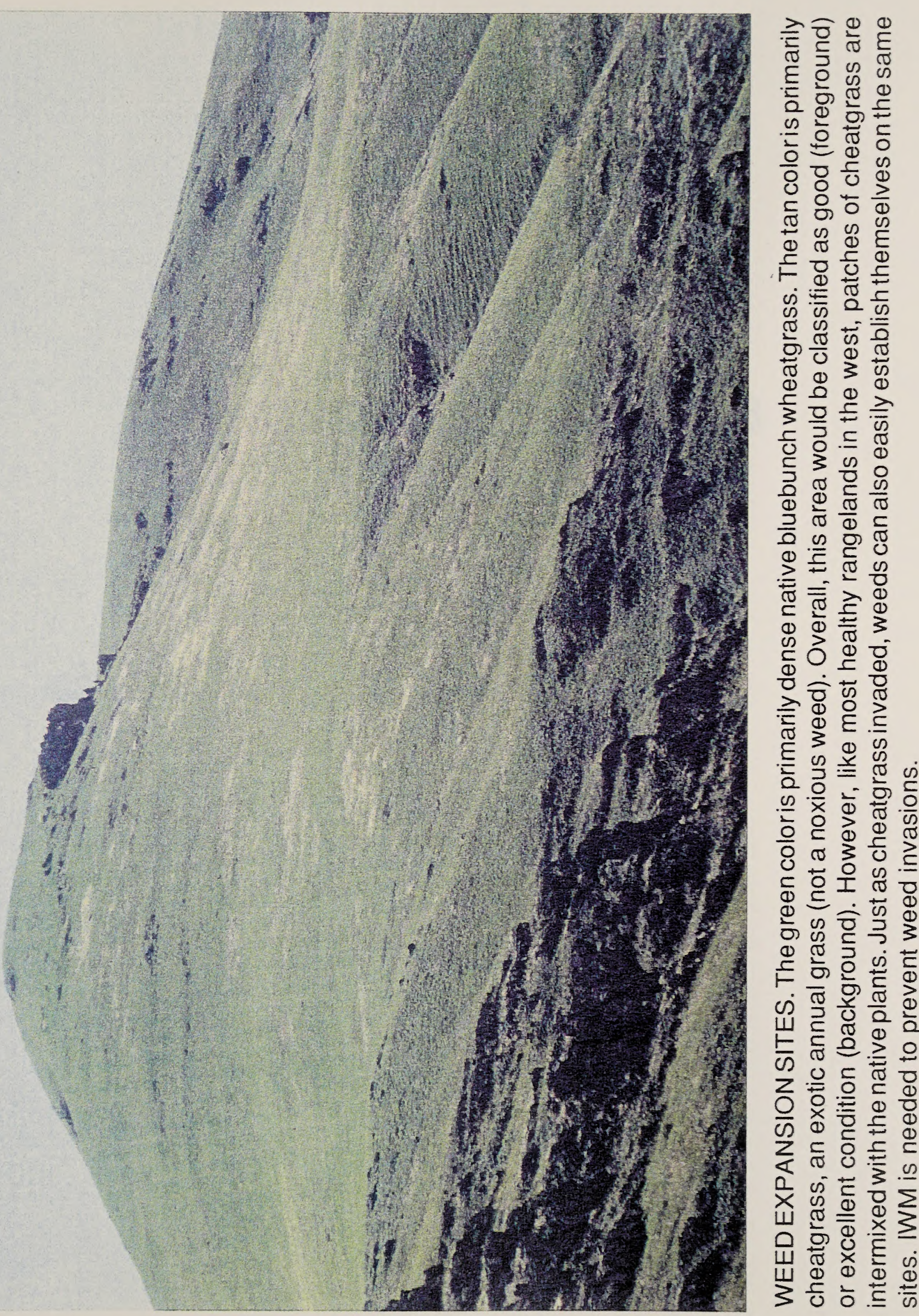
IMPACTS FROM NOXIOUS WEEDS 



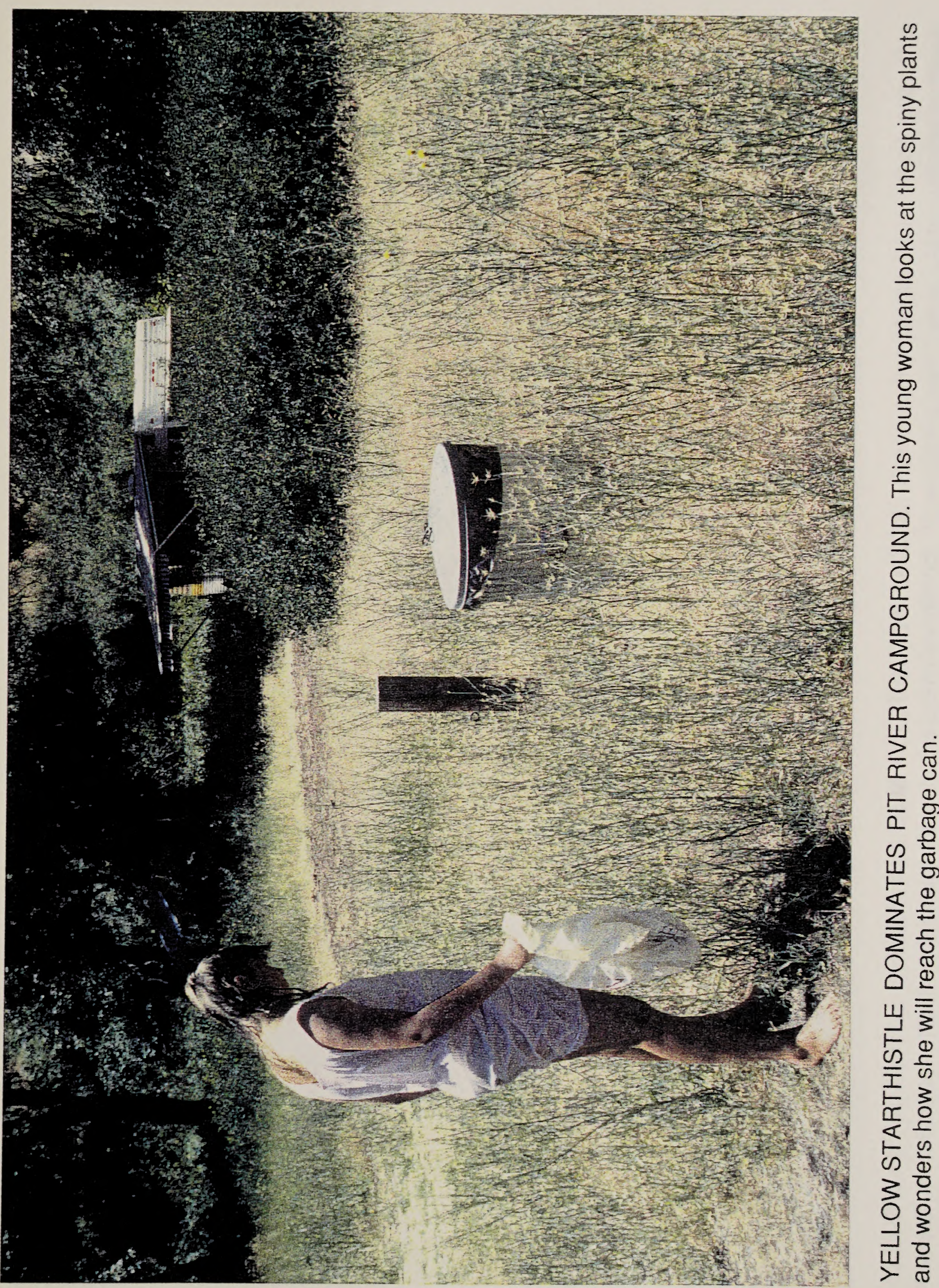




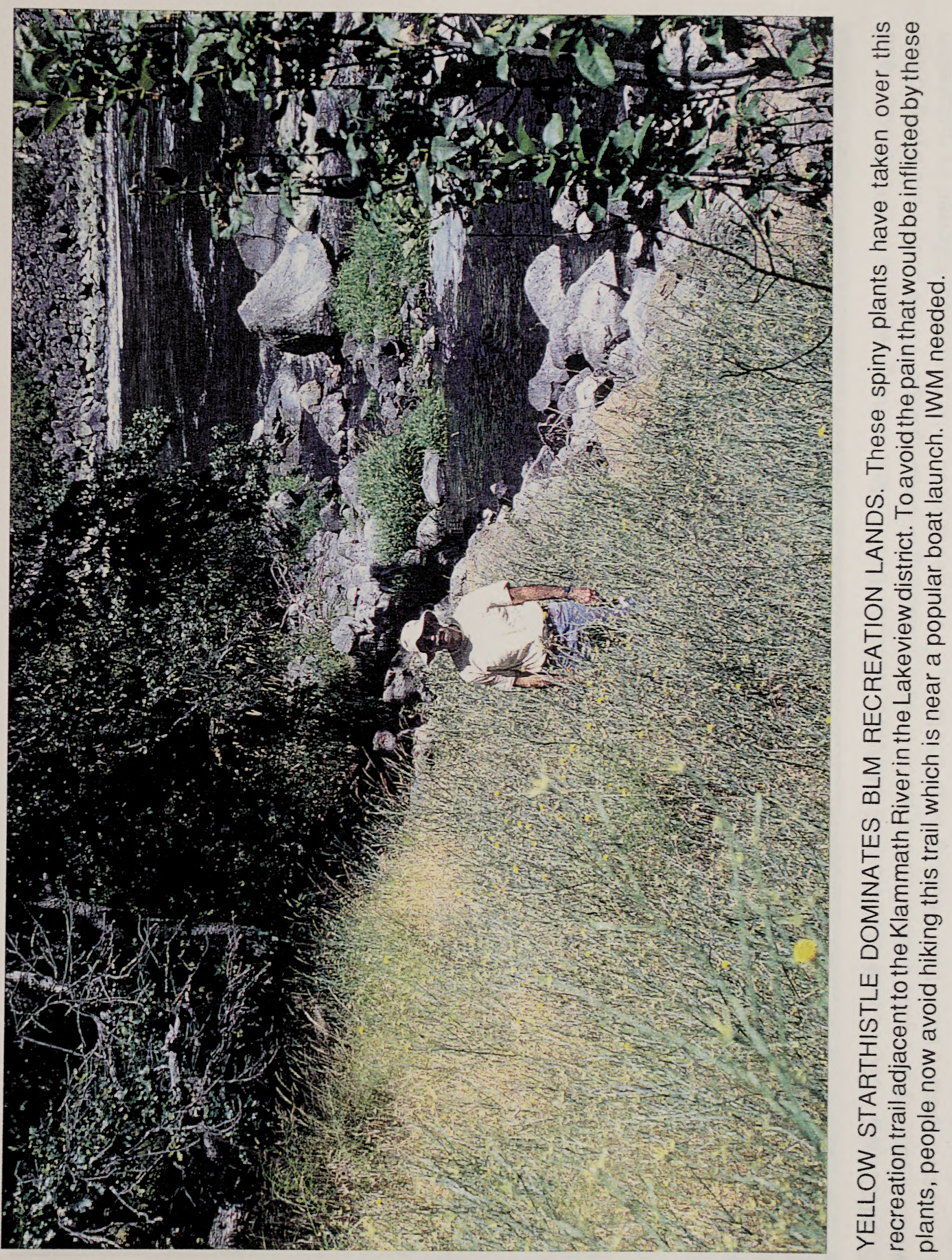





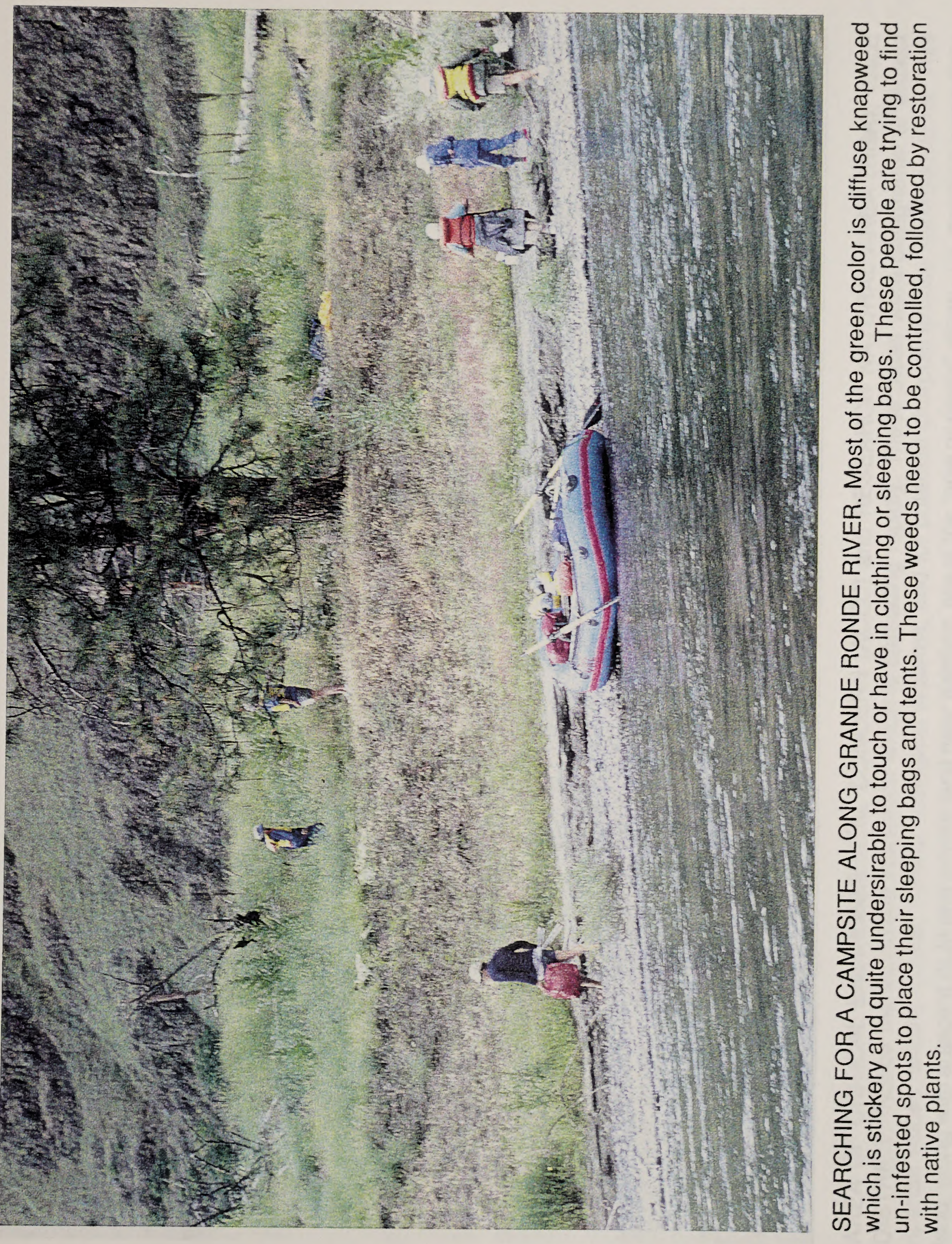





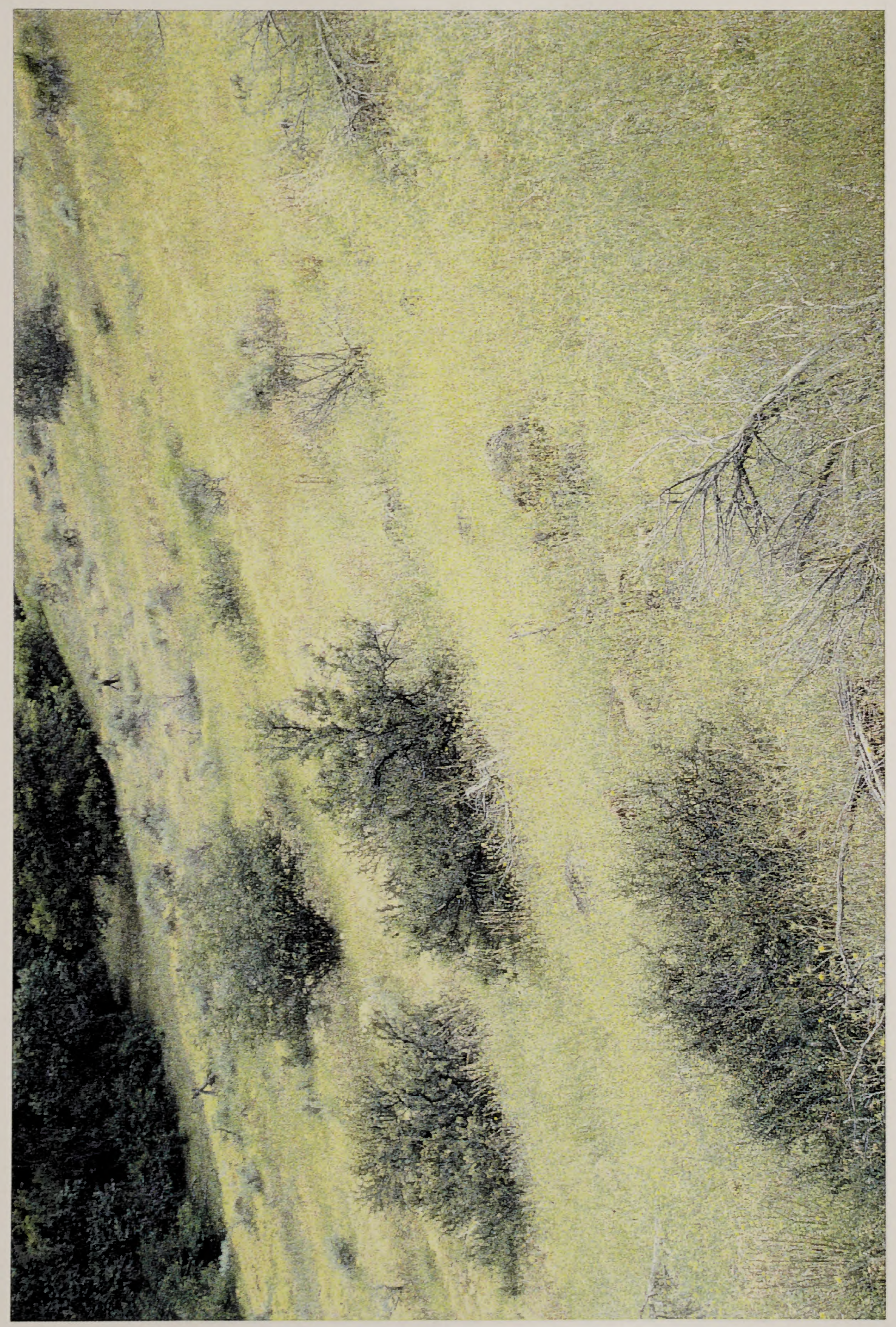

山苞岳

$>$ ○े

दे을 ह

之

—

띰흐 임

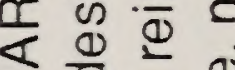

+0 电

¿ ¿

33 잉

舟要

$\sum \mathbb{\Phi}=$

त 은

บ

造

峞曽了

㟧之这。

풍흥ㅎㅇ

은 흔휴

ㅇํㅇำ

บับ

Uे के है

क के

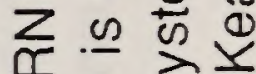

山्व के

$\sum_{3} \frac{0}{\frac{0}{5}}$

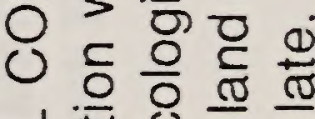

य西

క

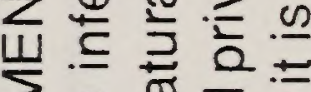

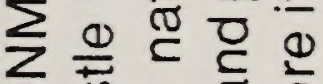

음

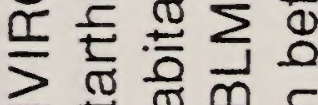

$\sum$ क

山。

过岳咅

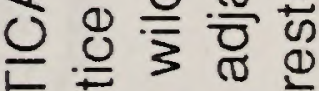

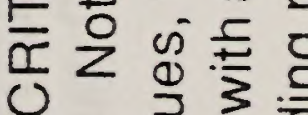

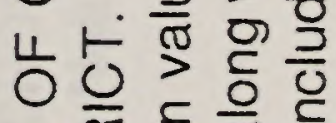

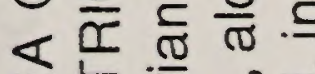

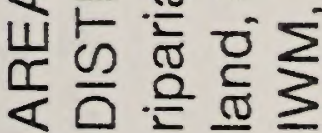




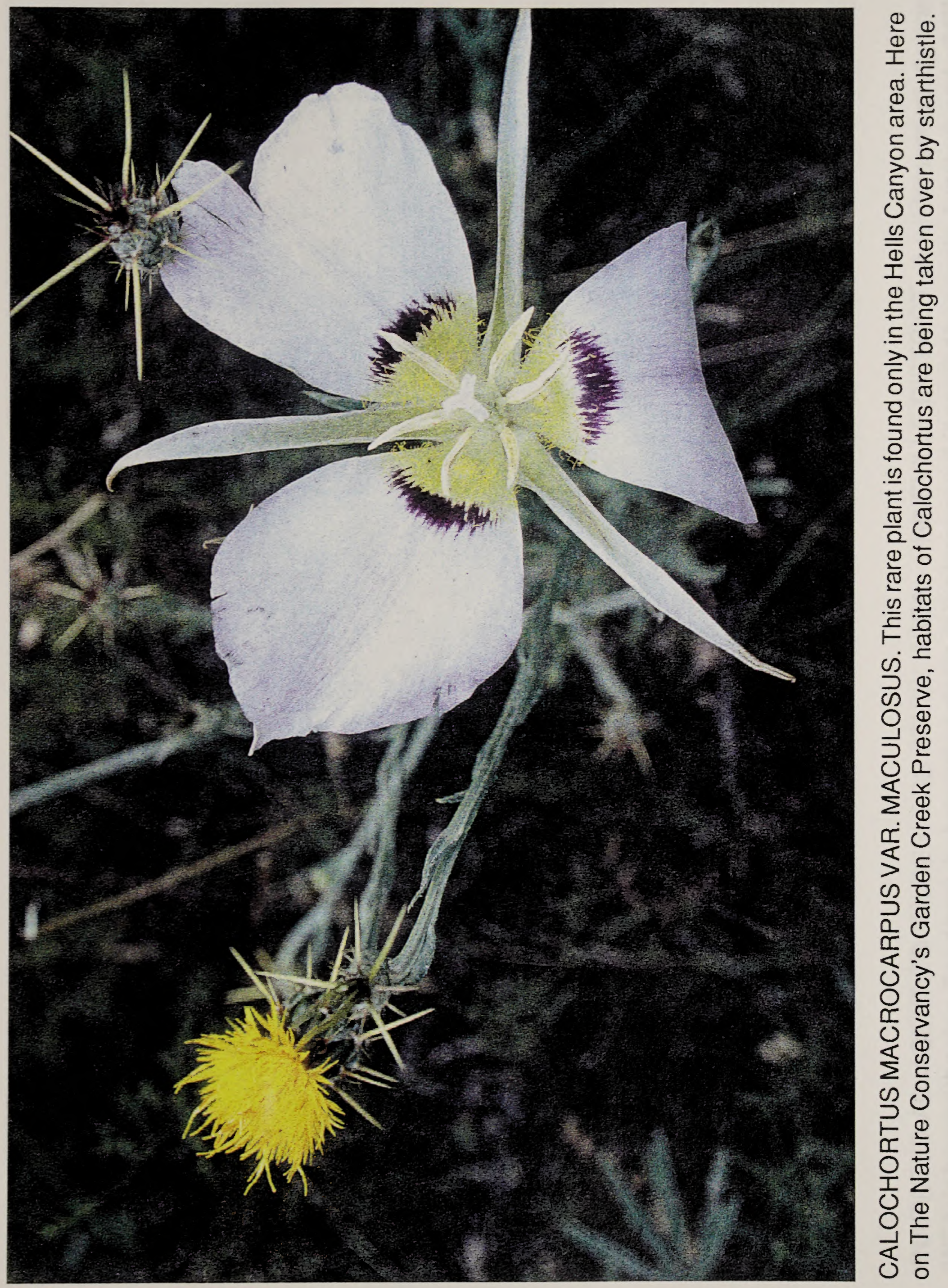





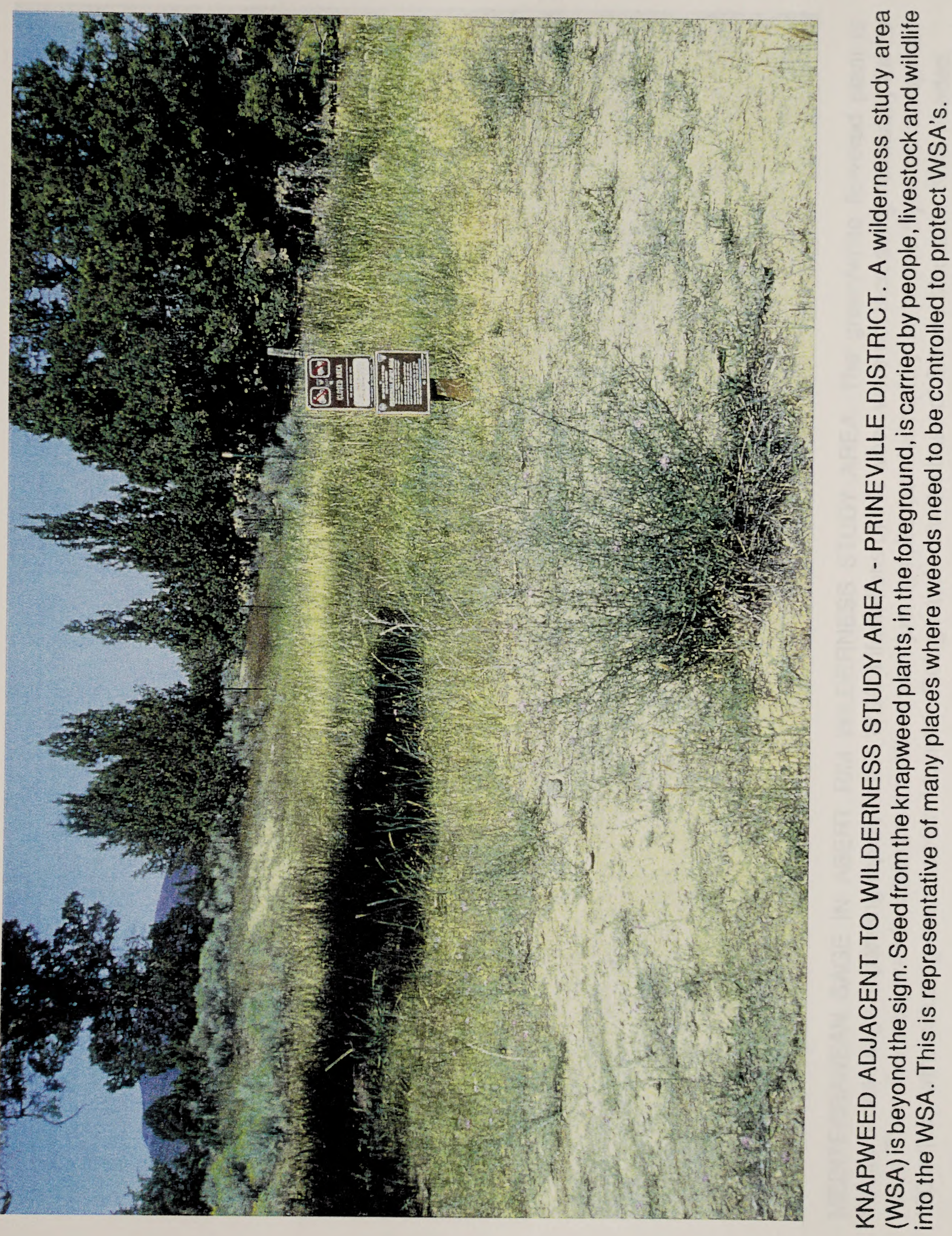




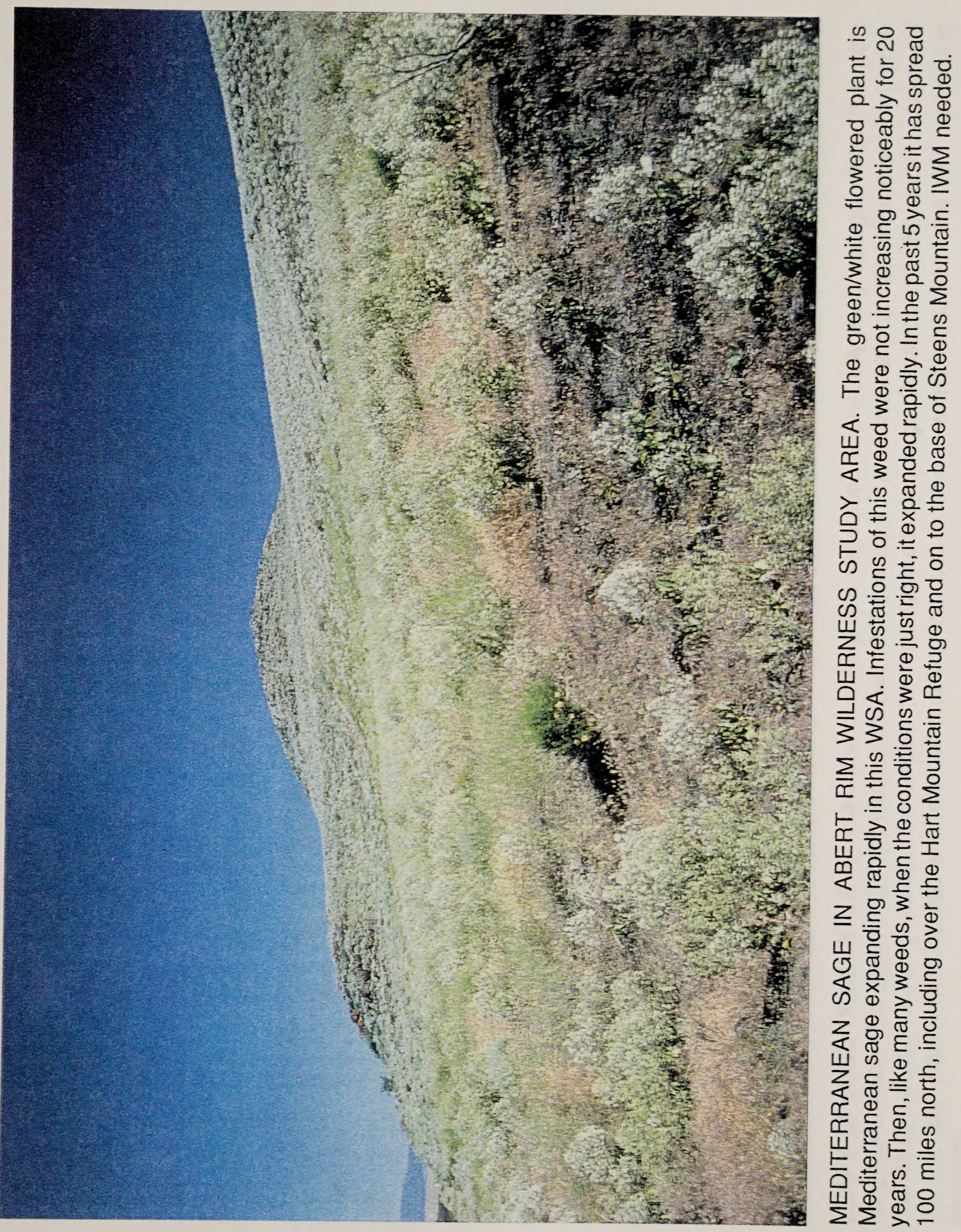




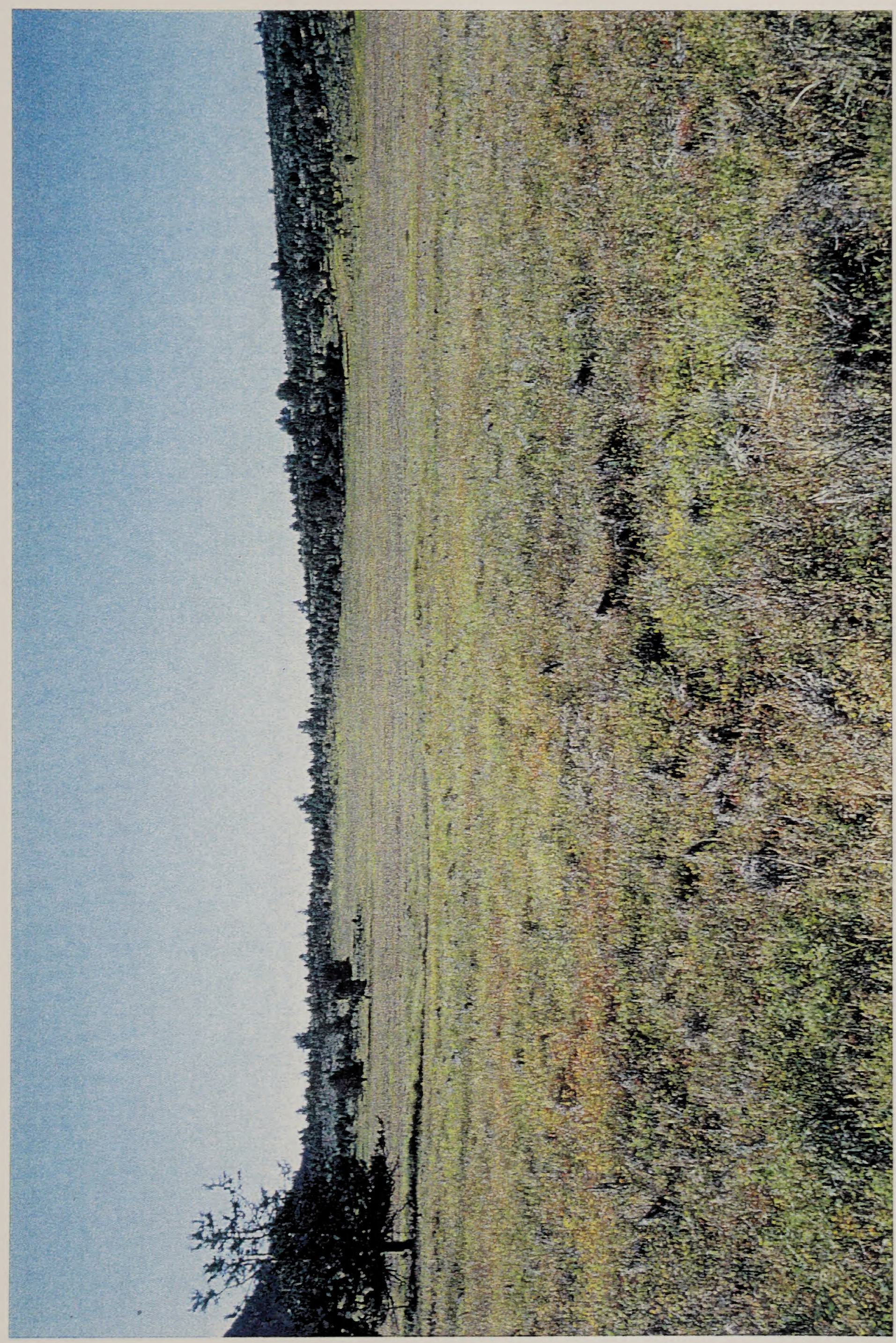

ญ 든

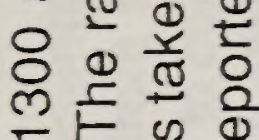

-

을 응 응

i

О人ㅀㅇ

כ. $\cong$

क웡흐음

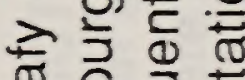

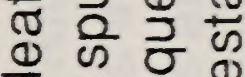

는

즌응

ळ山

흘

요 \&

ᄃ

음

\% 0 \%

옥

ग

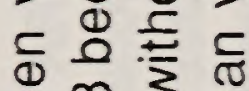

ఏ $\infty$ 으

힝요 을

등

당유응

○范

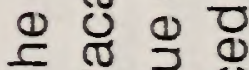

당 $\frac{\pi}{3} \frac{7}{2}$

I.

事

这

ᄄᄄ

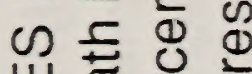

山

Eह क

트응

$\sum \frac{\pi}{\square} \stackrel{\Phi}{\square}$

잉ㅎㅇㅇ

은

山드음 응

प) 엄

兵

a

の 읃응

$\succ \frac{\pi}{0}$ 的

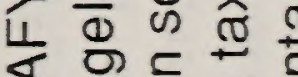

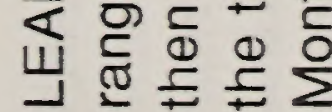





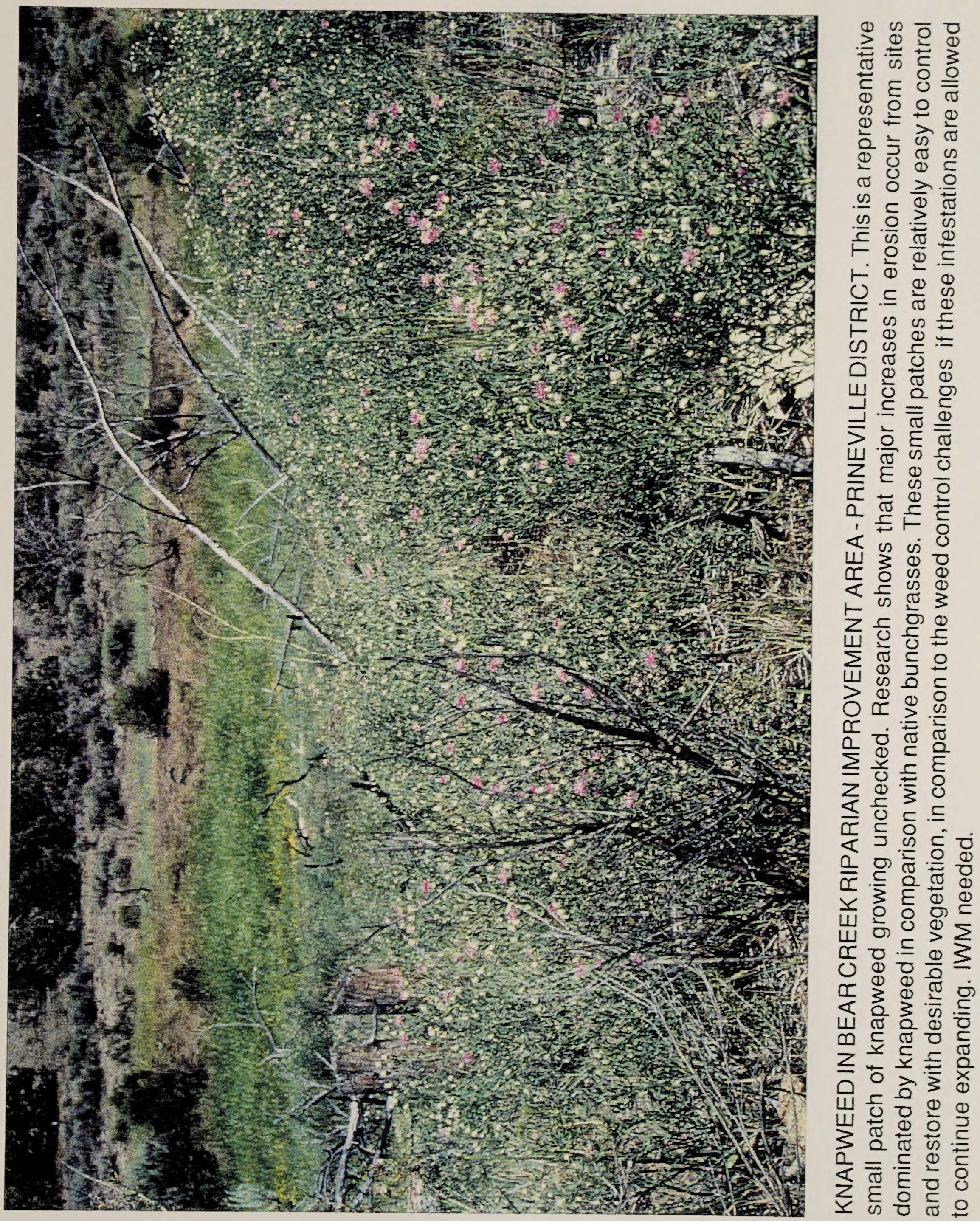


INVENTORY EXAMPLES 



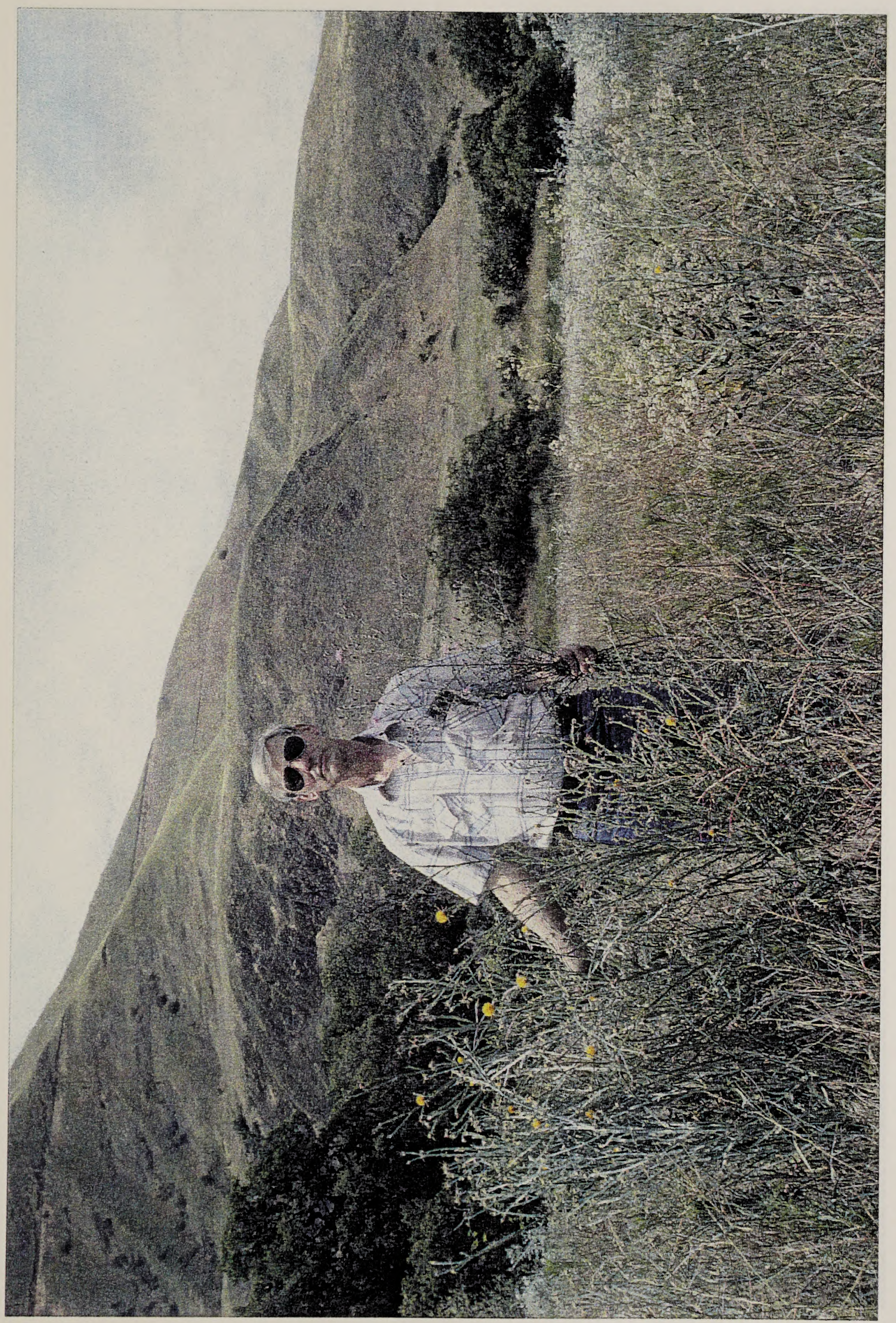

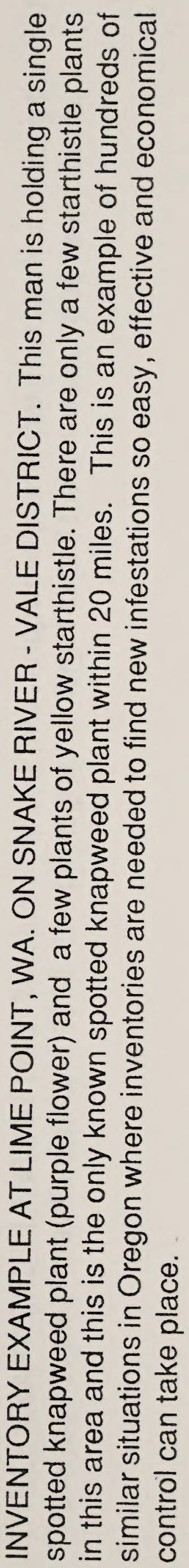




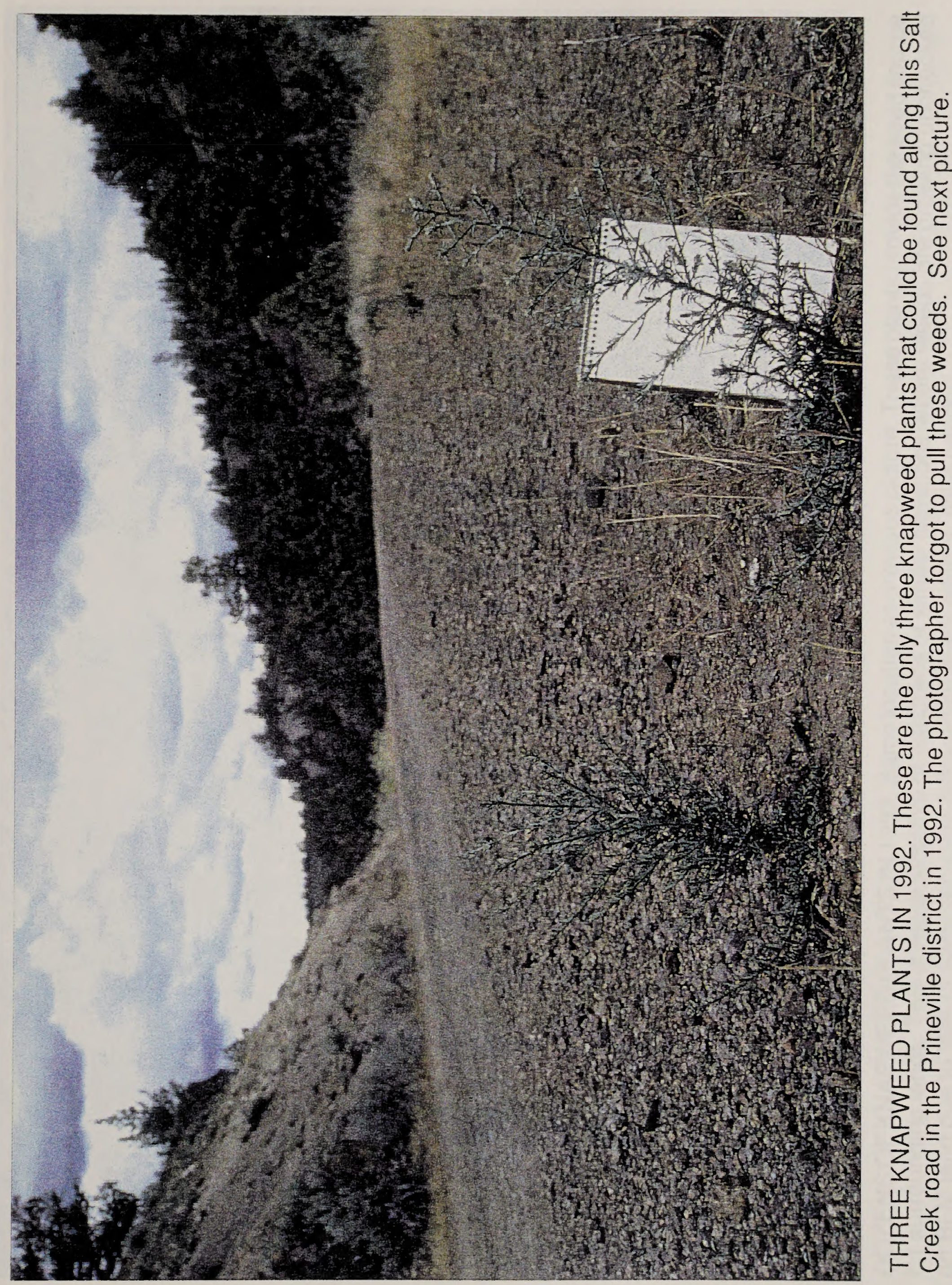





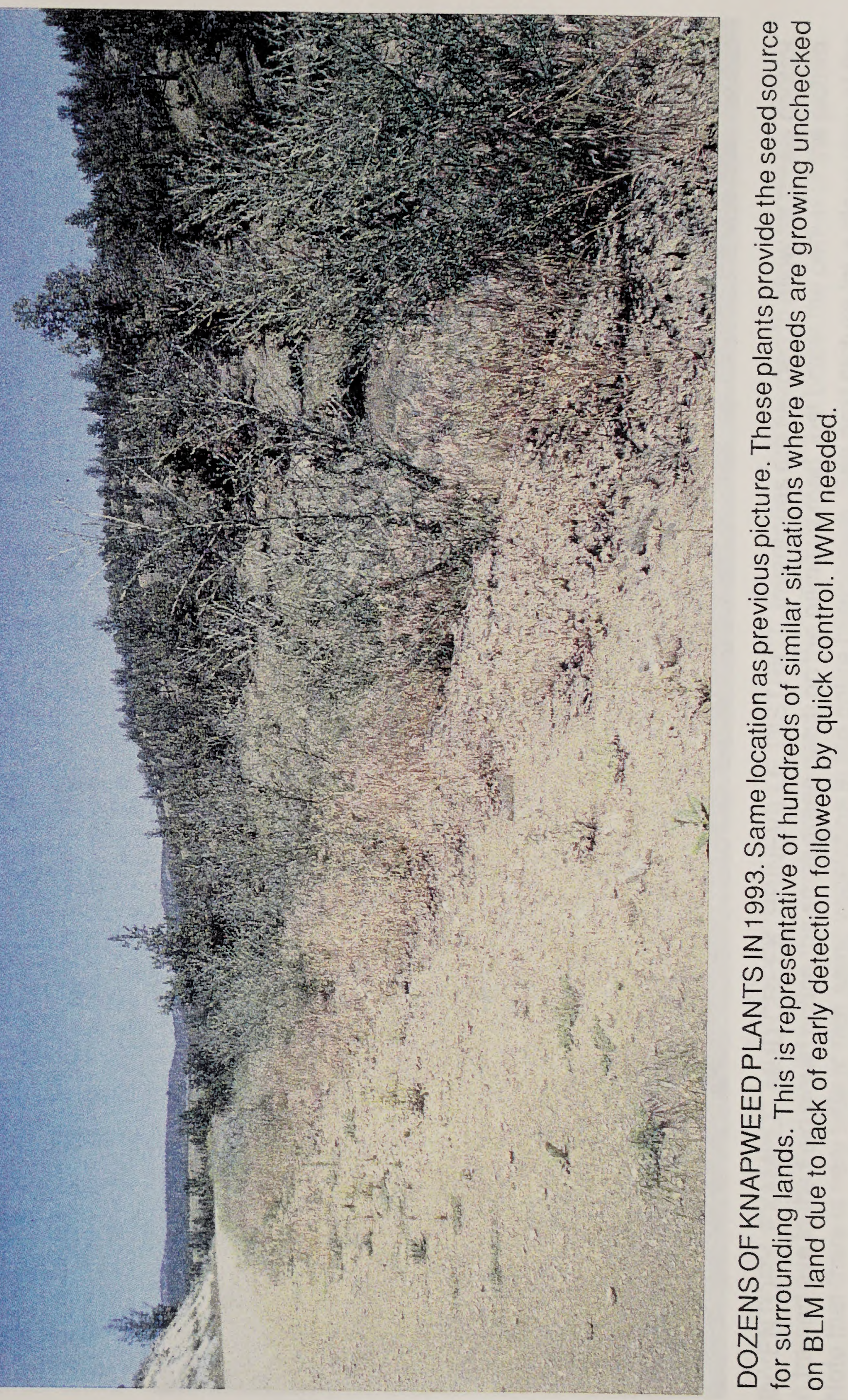





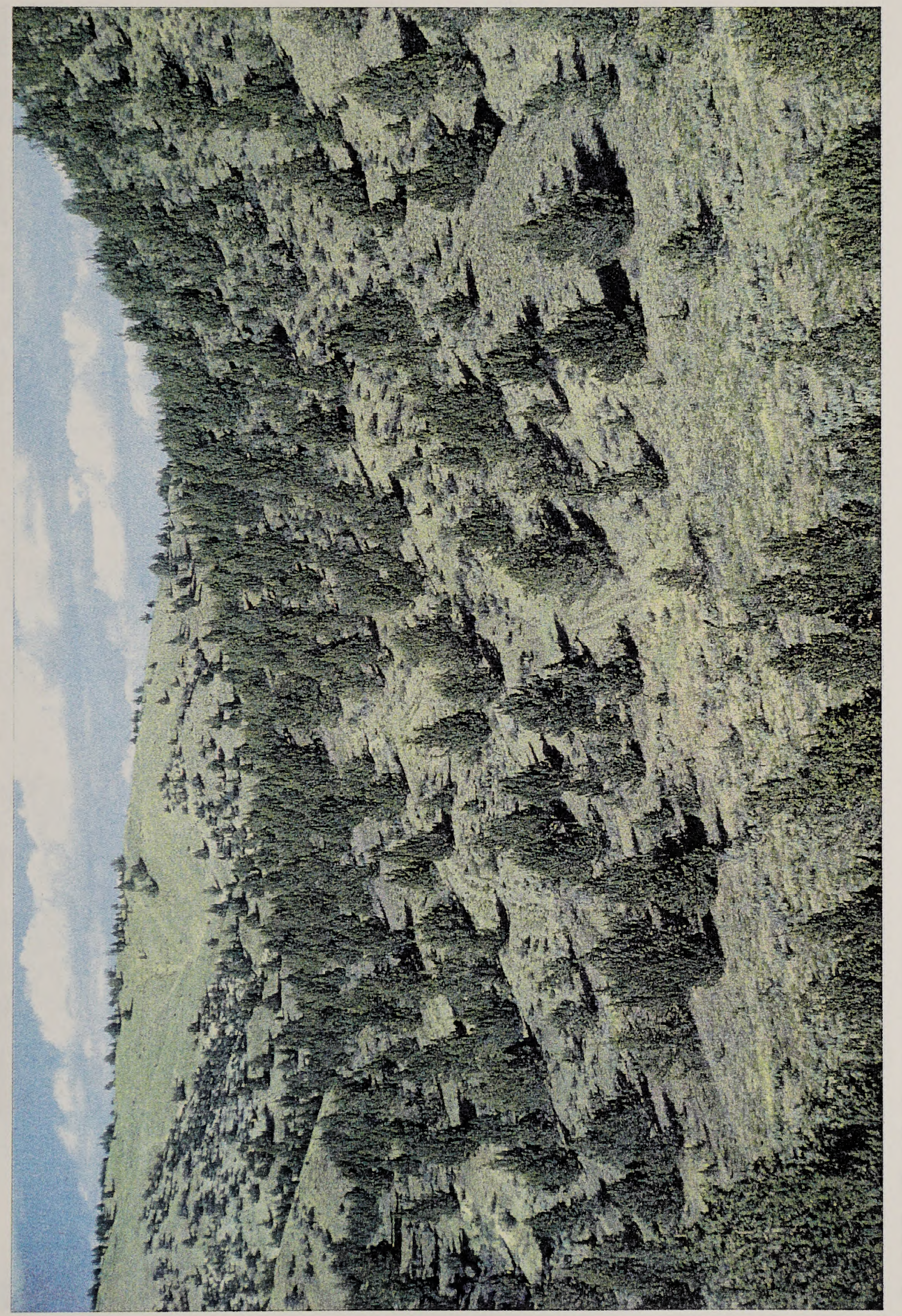

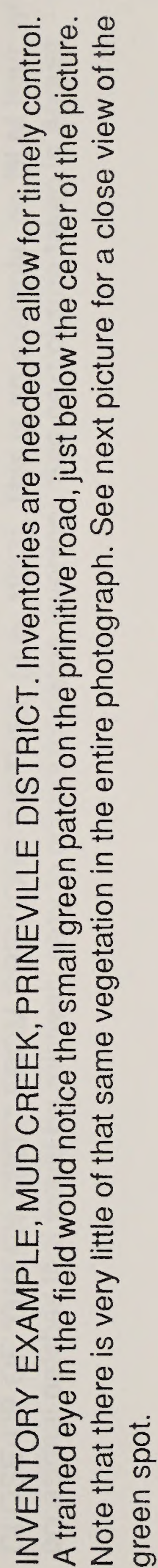




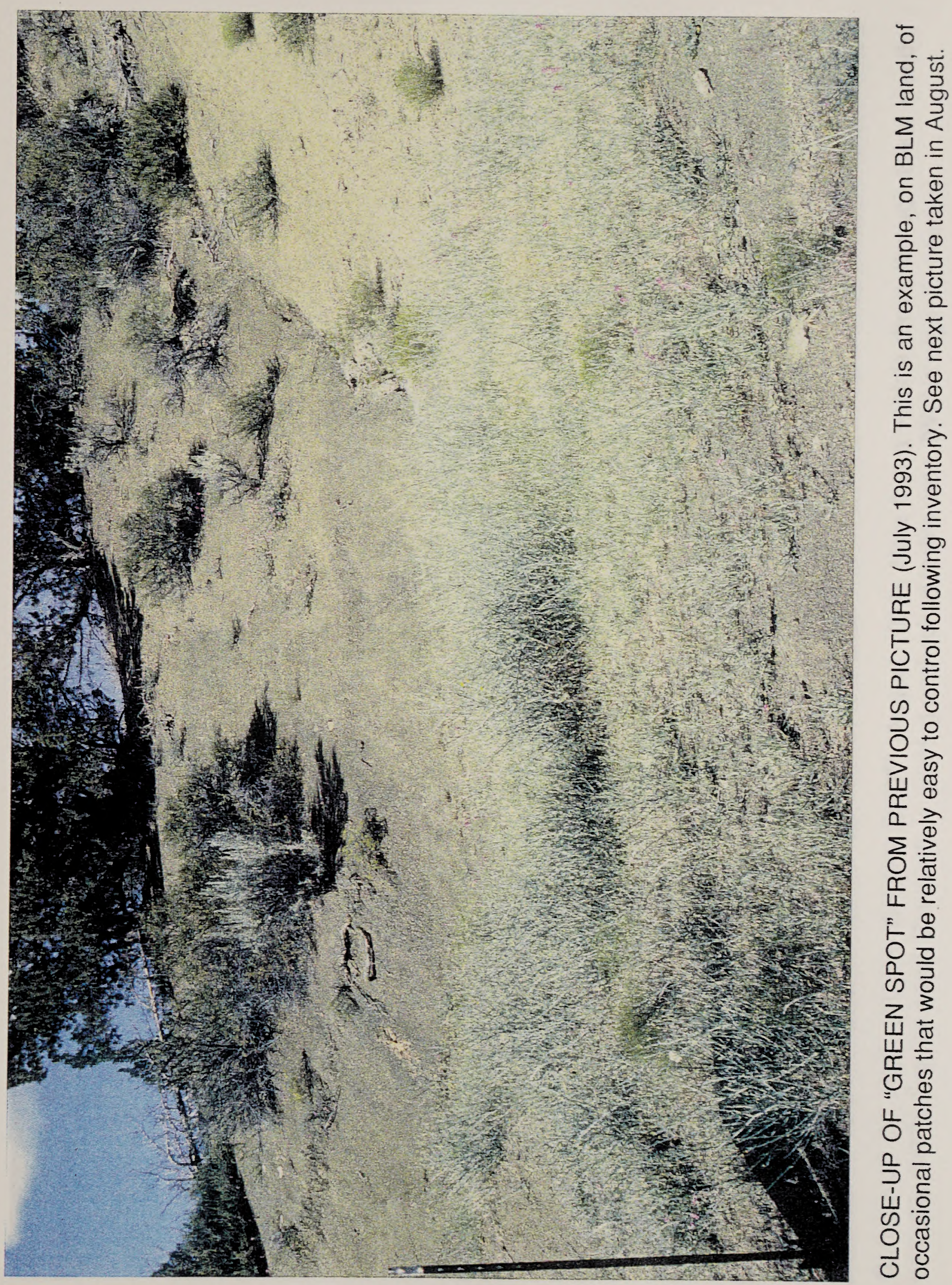





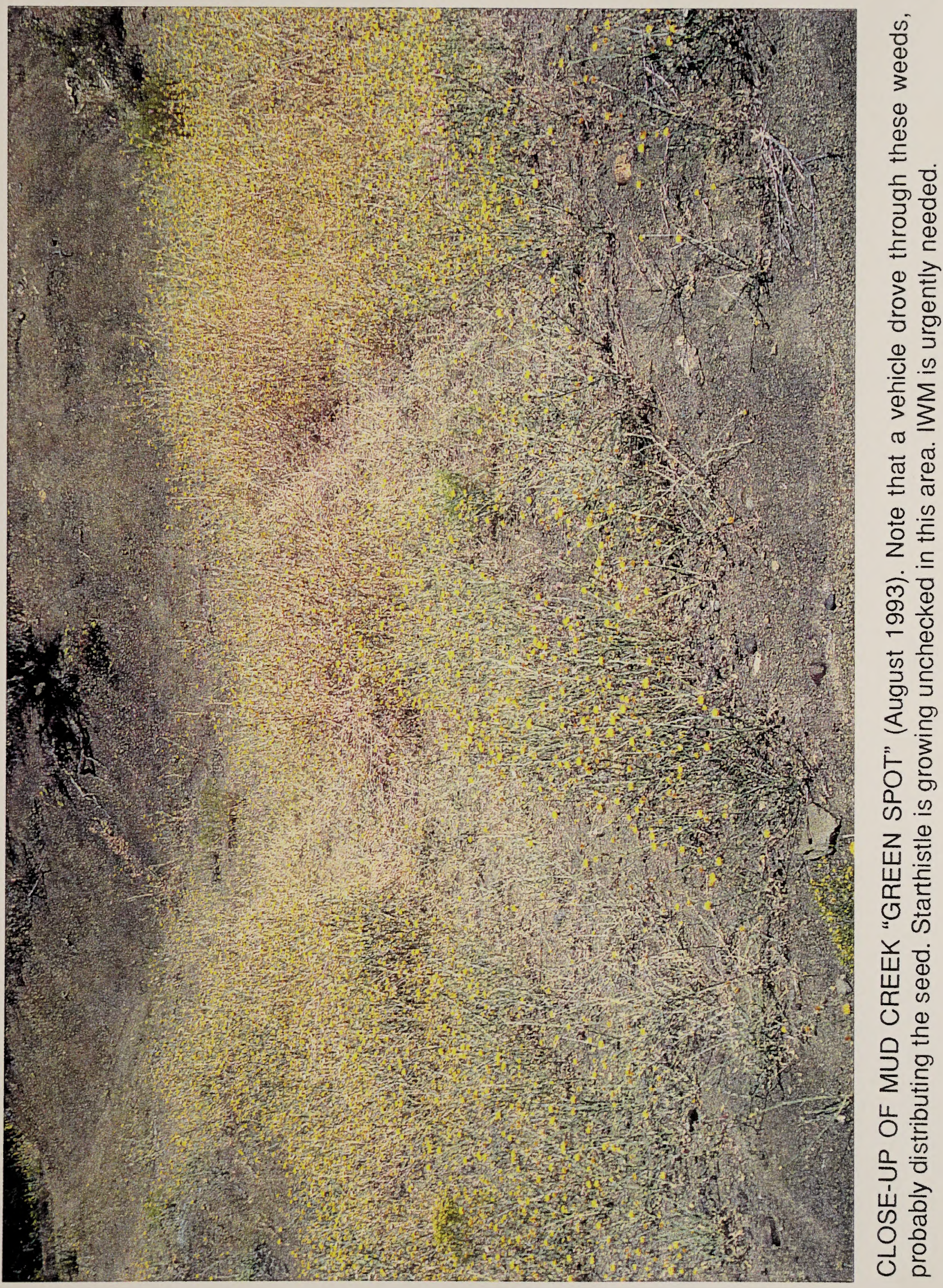



WEED CONTROL EXAMPLES 



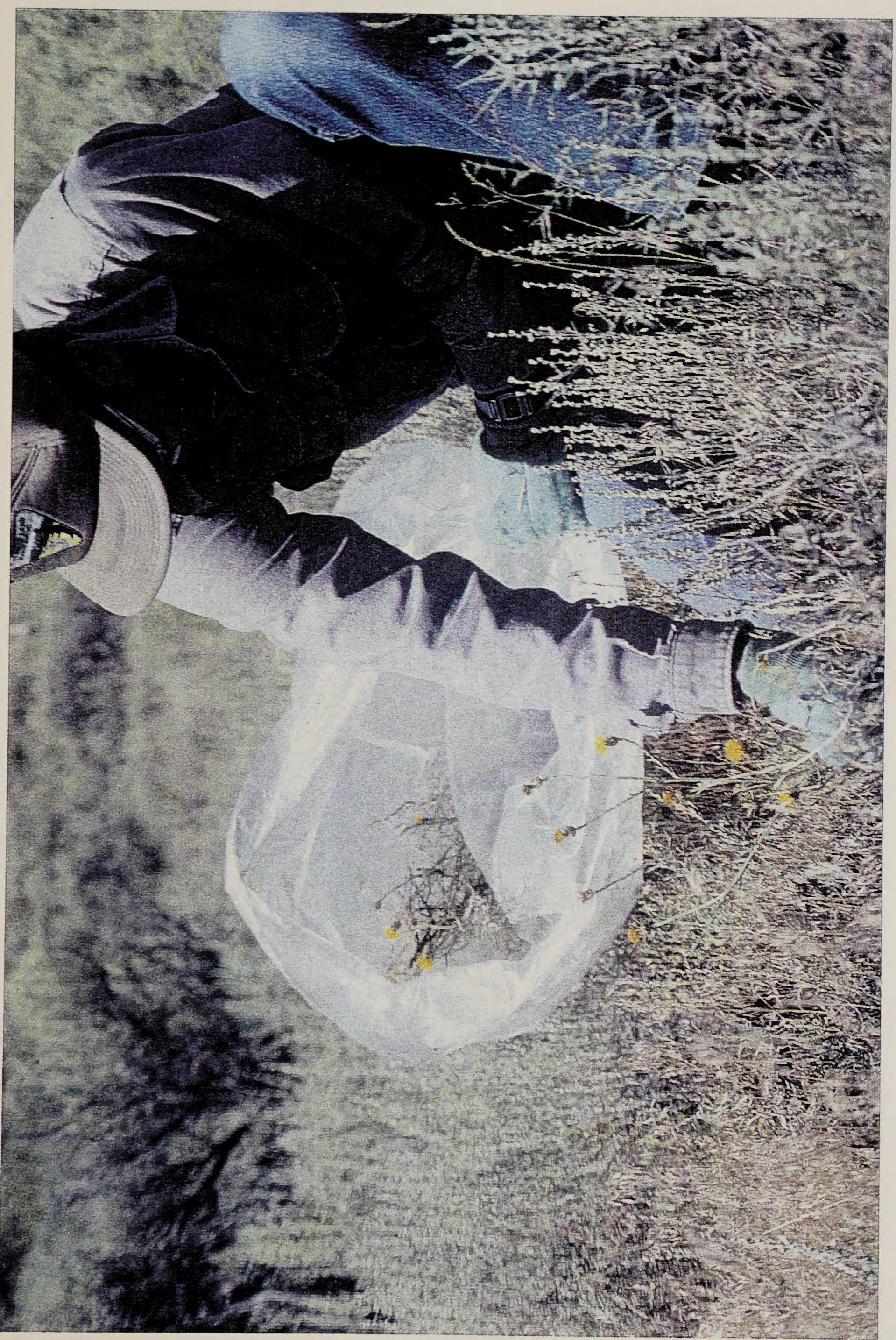

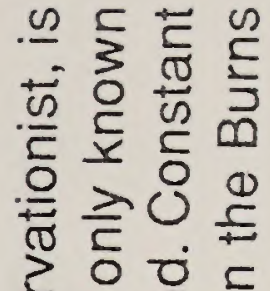

$\geq 0$ 으

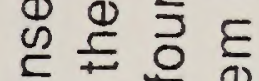

ᄋำ

(1) 里

Oृf क व

त 3

我

$\sum$ ब $\overline{\bar{\varepsilon}}$

जิ $\frac{5}{3}$

- $\sum^{0}$

运

승

过

व $\square$

(1) वे

川

Z.

$\varangle$

三®

ไั

잉도

$\sum$ 이

0 ชิ

기음

㟧

$\overrightarrow{0} \leq 50$

乙

Z范荧

Ш I

ए心

Q

늠 응

$\simeq \stackrel{0}{\lambda}$

正它至

凹

3 宁

O $\frac{\pi}{2} \equiv 0$

J

Ш

$>$ 흔은

(1) $\frac{0}{5}$

도응ㄹ

马苛䒕

즈

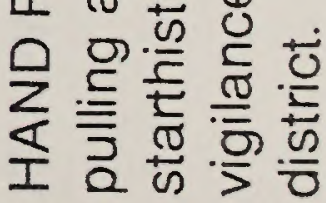




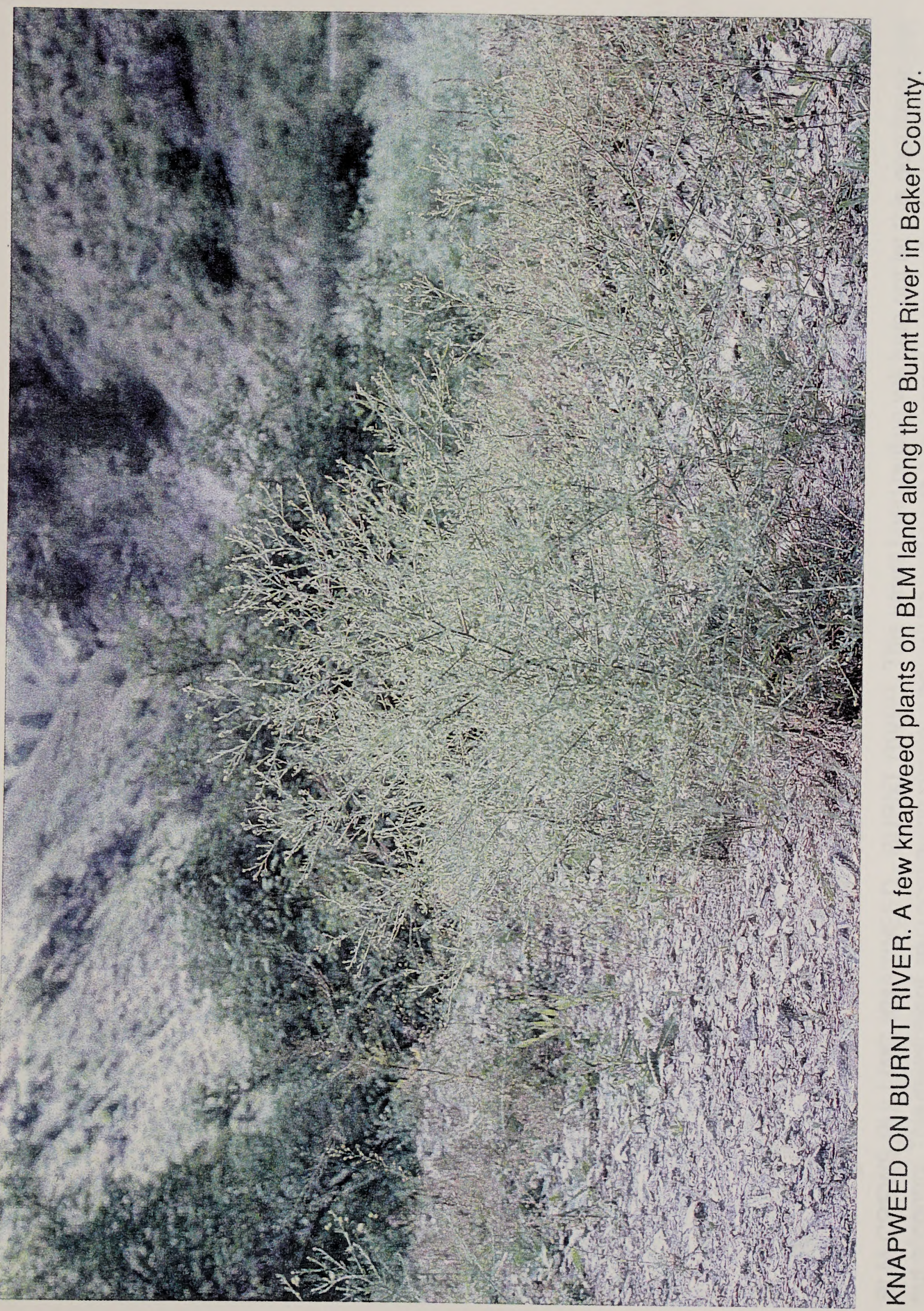




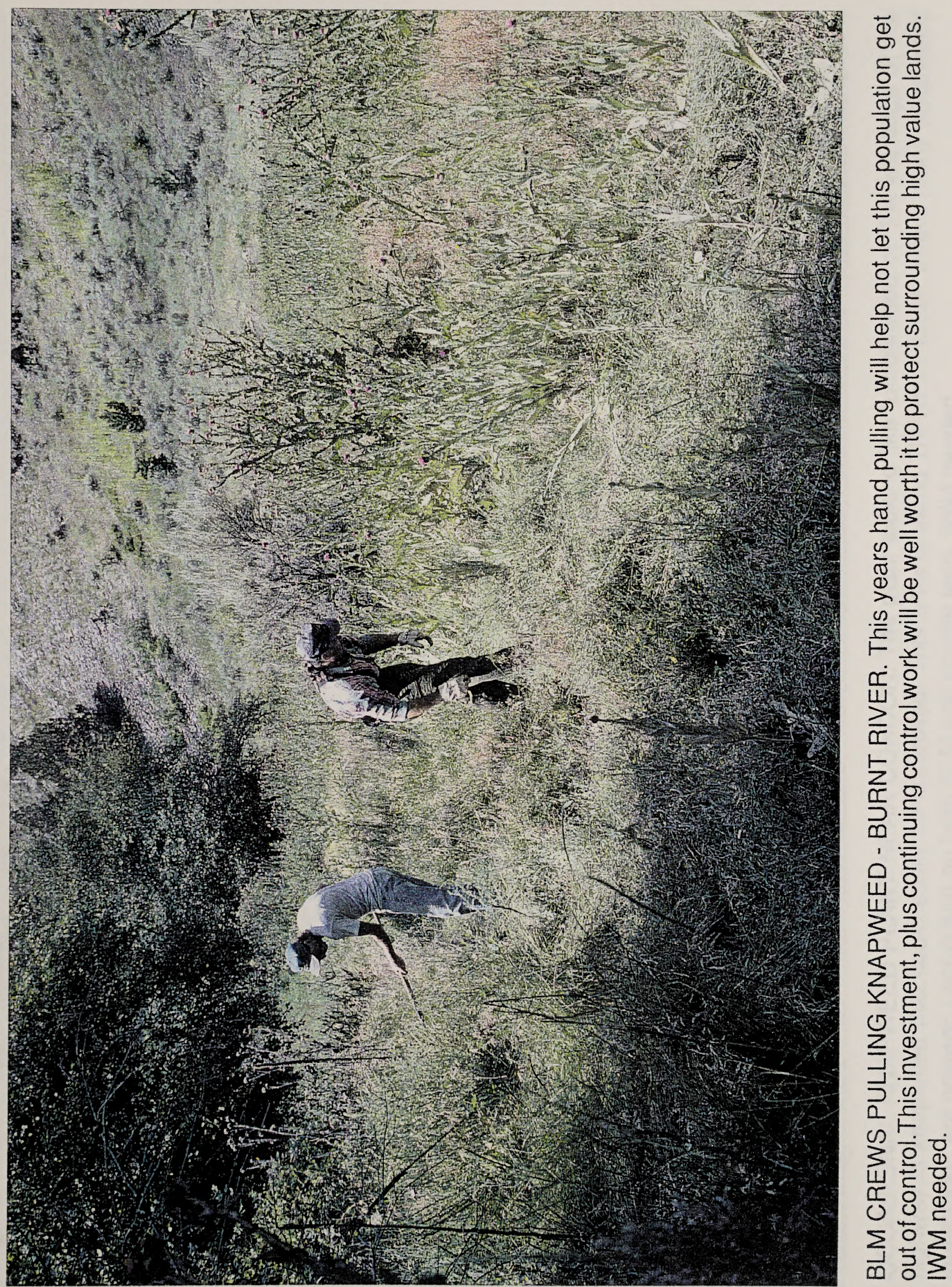



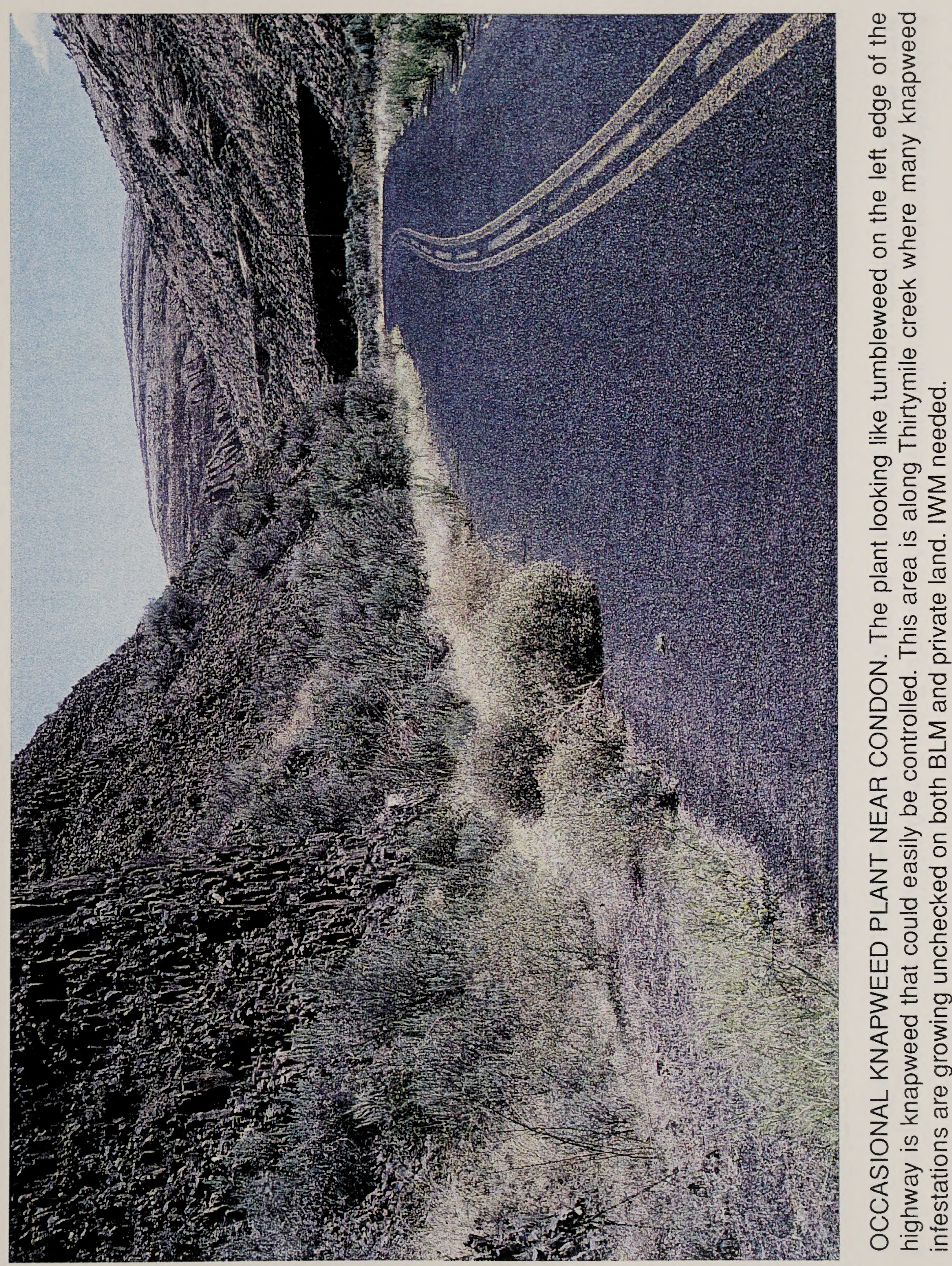



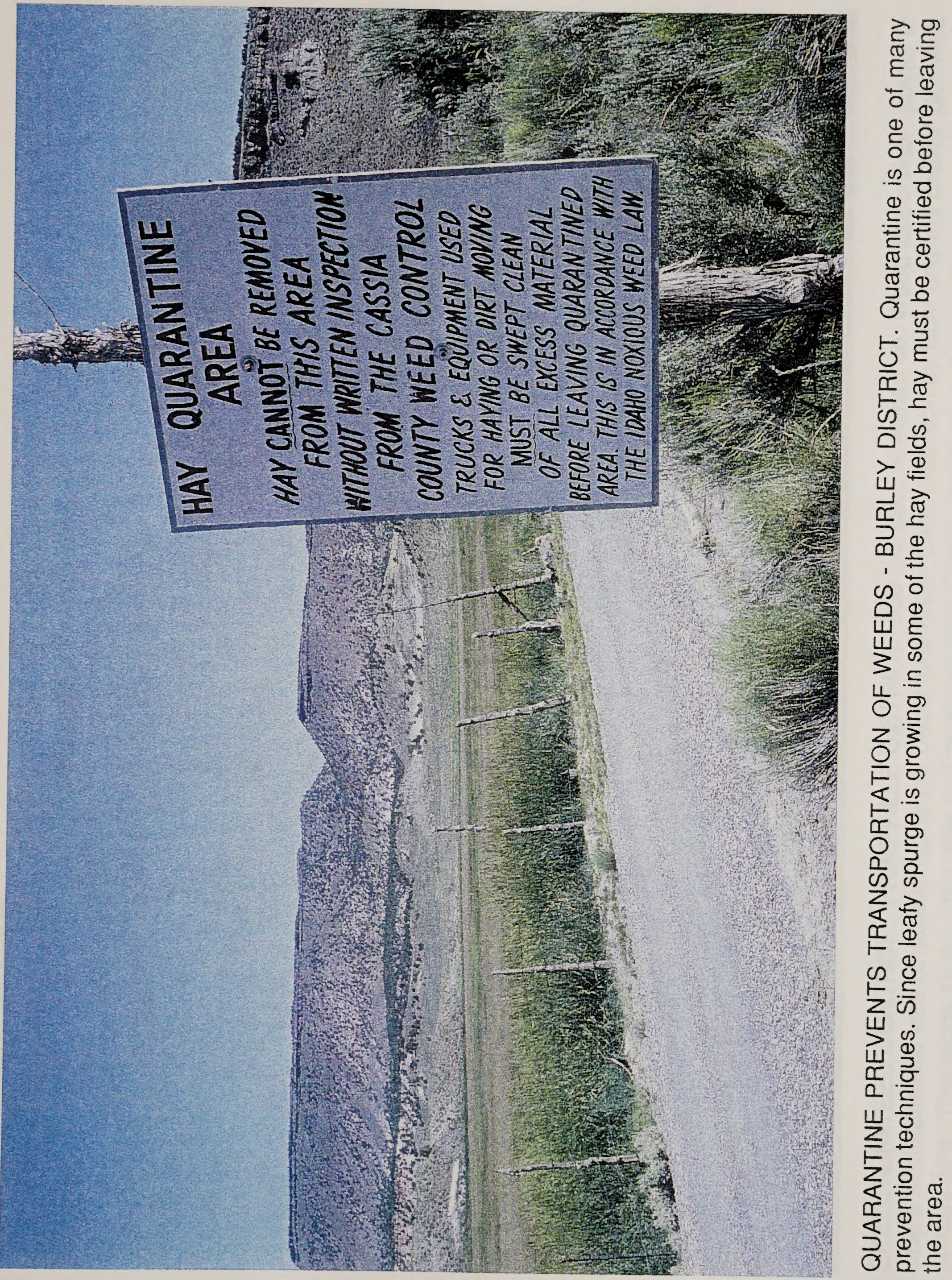




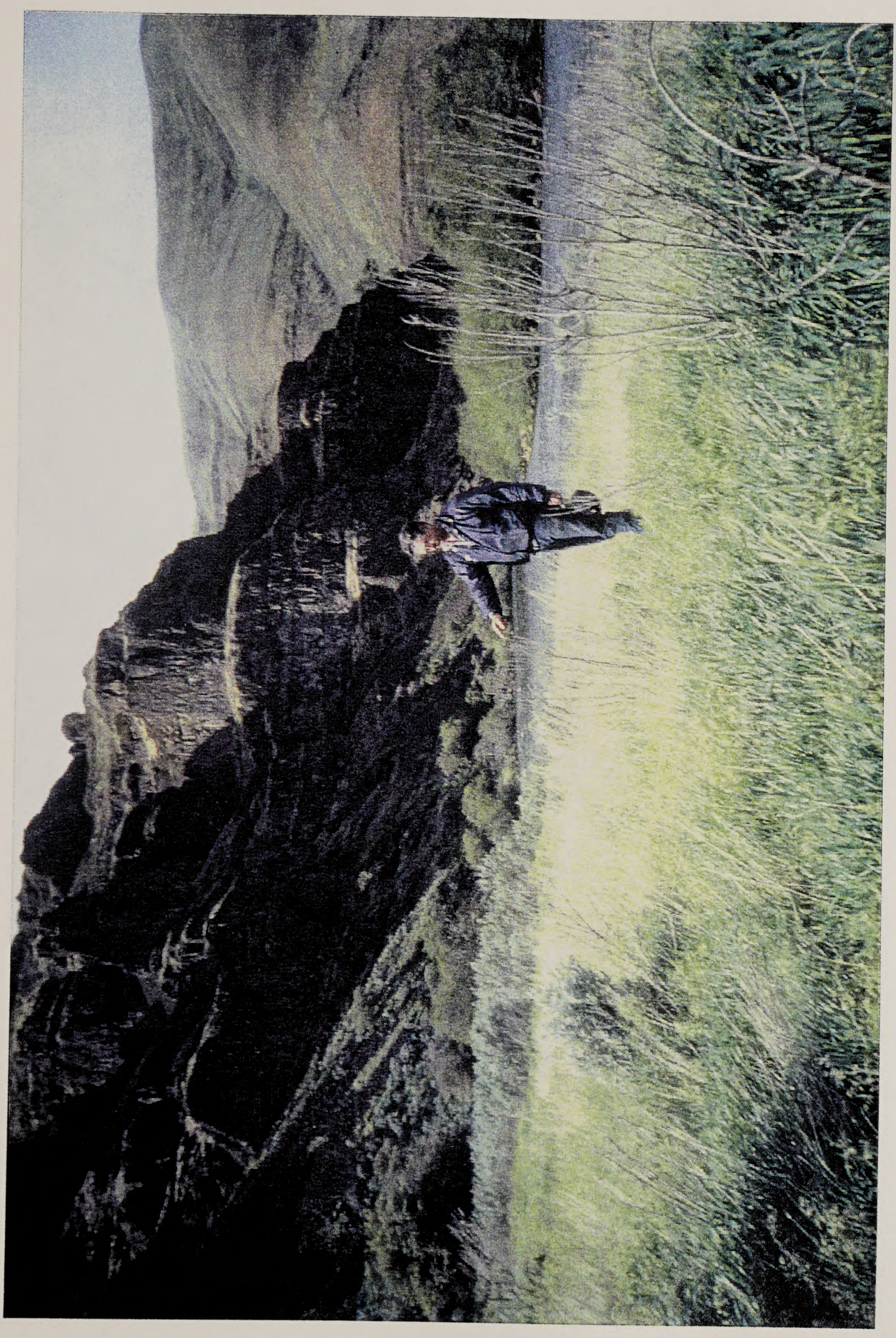

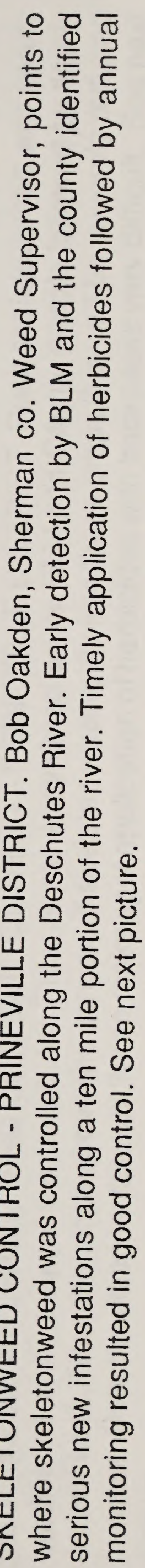




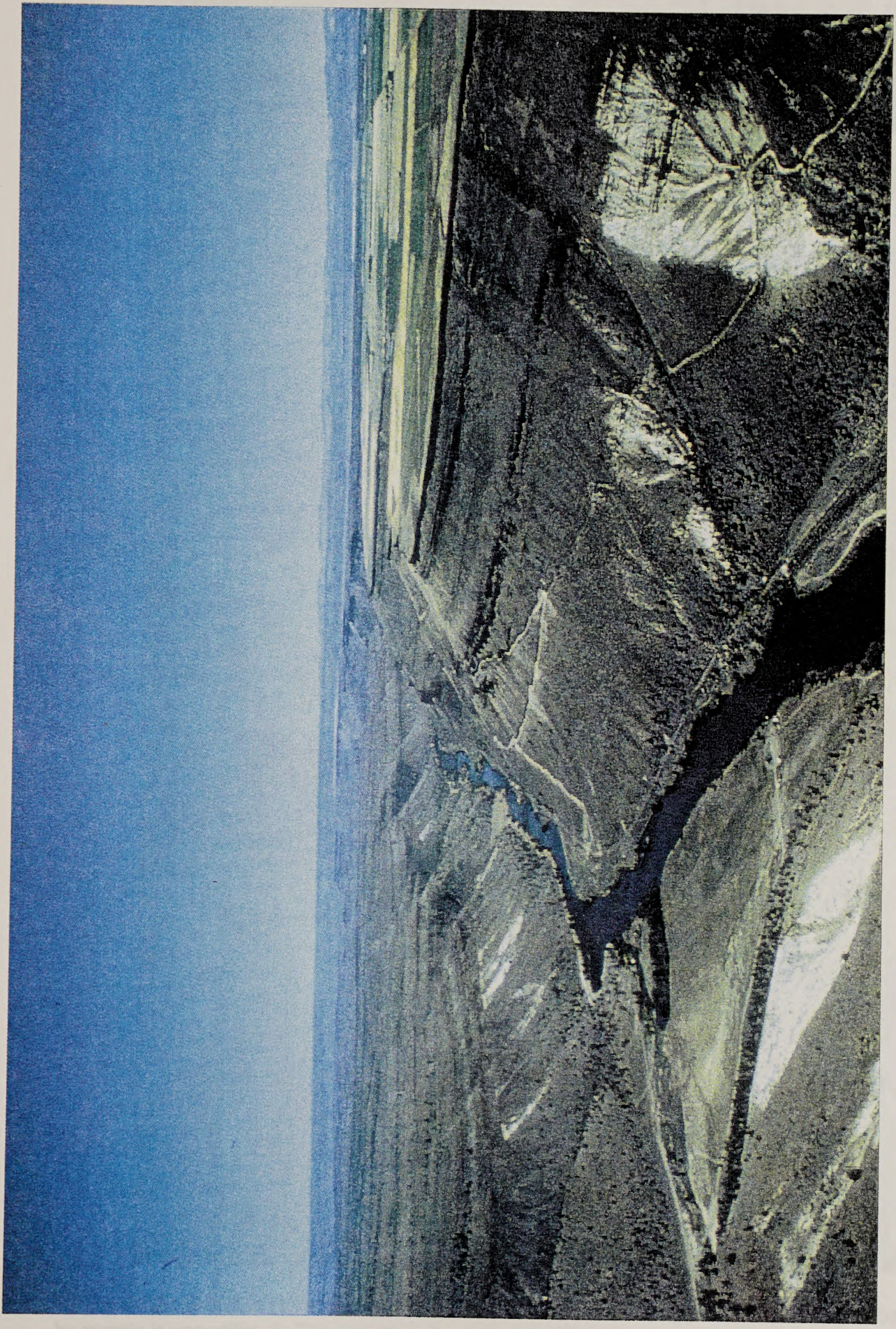

진저일

Q

(1) 즌

उ

잉

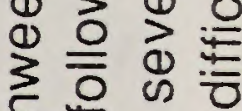

○

过 잉

ब

ज这

兵

व

$\vdash 0$ 응

언

エ त ब

क $\sum 0$

可要

山 즈트응

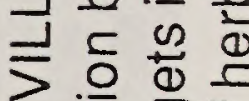

西

过

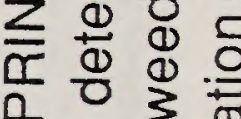

135

i 춘

Ш丷

우

$\sum \stackrel{2}{2}$

○

ㄴํㅇ ¿

Ш $\gtrsim$ है

Ш

क ब

ᄂ

○ 讨

일

뜨 ส

选电的

풍응

$\checkmark$ ○

【I Q

ш $\overline{\bar{E}}$

ॠ

的

山 둥후

5 웡훈

I 3

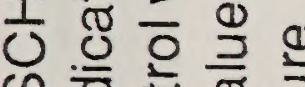

क एक

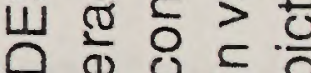





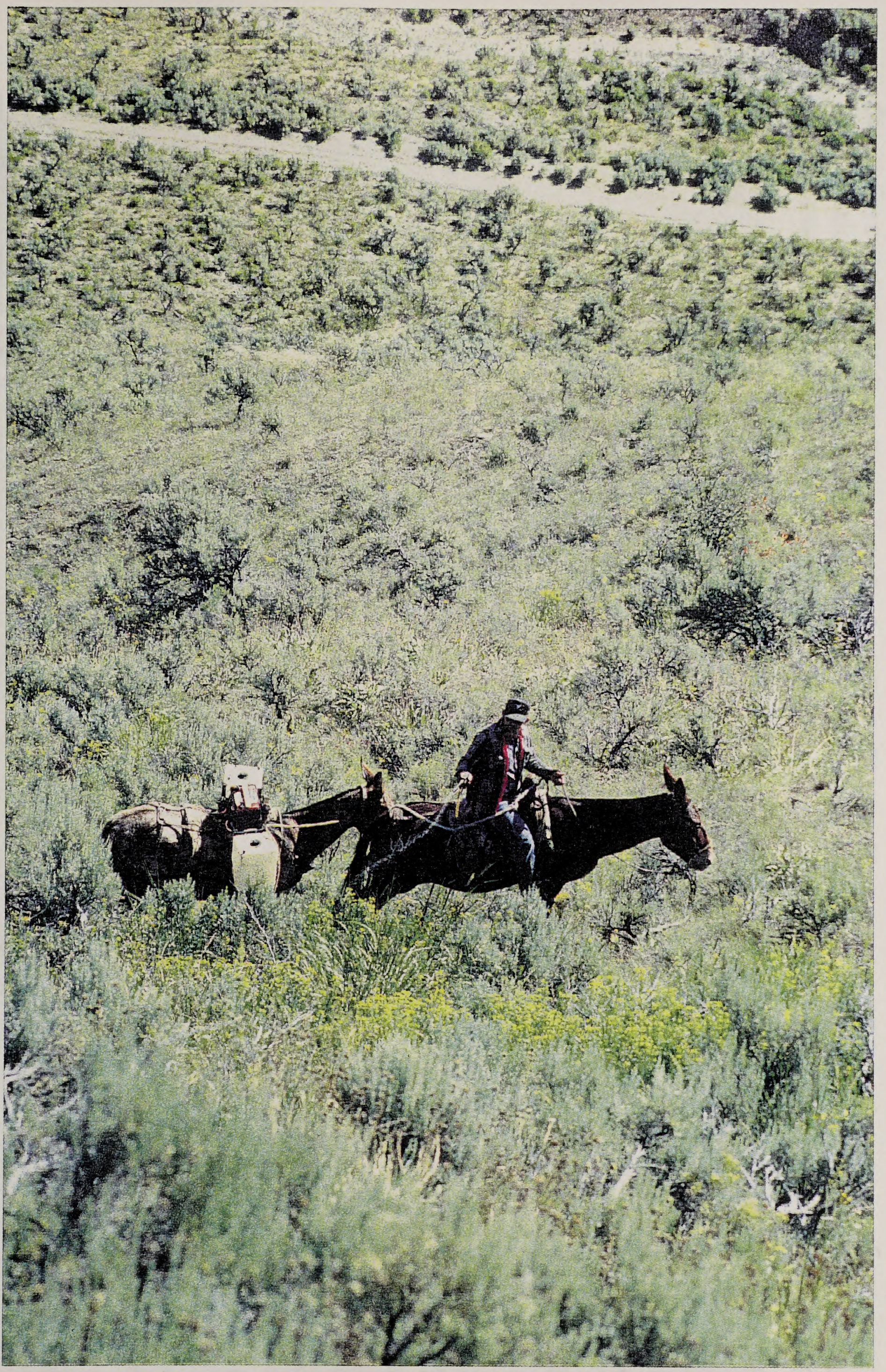

HERBICIDE APPLICATIONIN STEEP TERRAIN. Sometimes the terrain is so steep that "backpack" spraying by people is very difficult. The rear mule is equipped with tanks, battery and pump that delivers the herbicide in a hose to the man on the other mule. Small patches of leafy spurge (yellow/green beside mules) are being very selectively spot sprayed on BLM land near Burley, Idaho. 



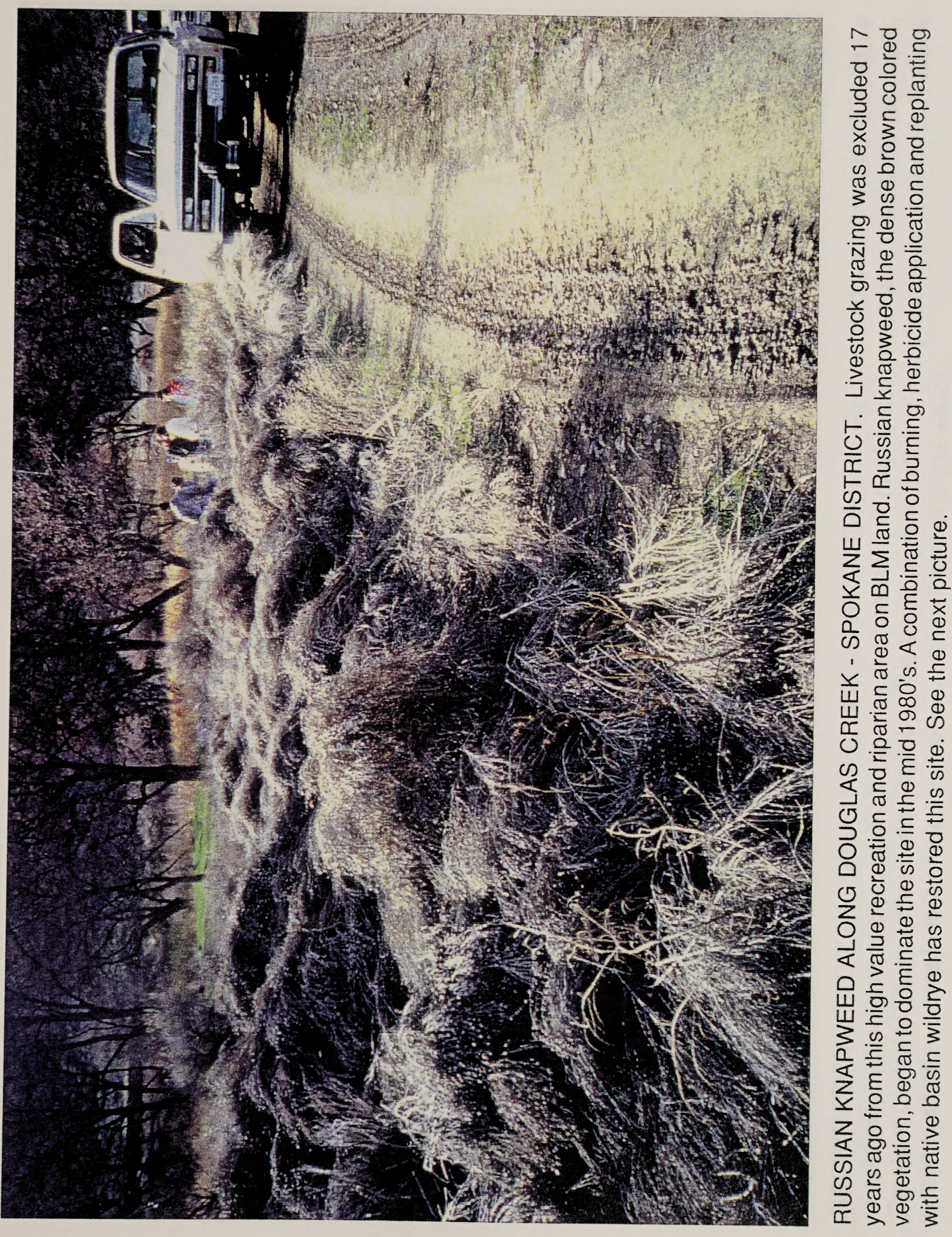




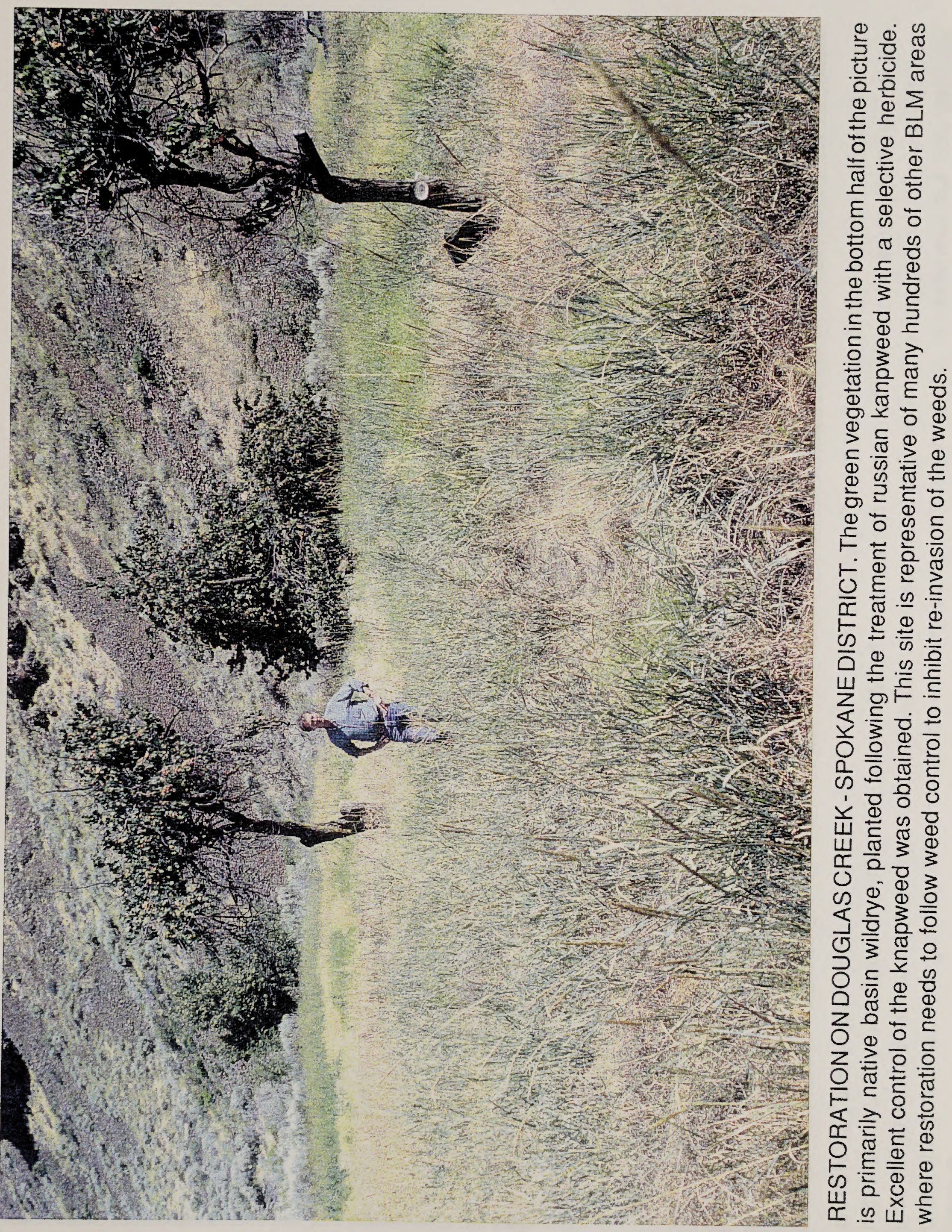





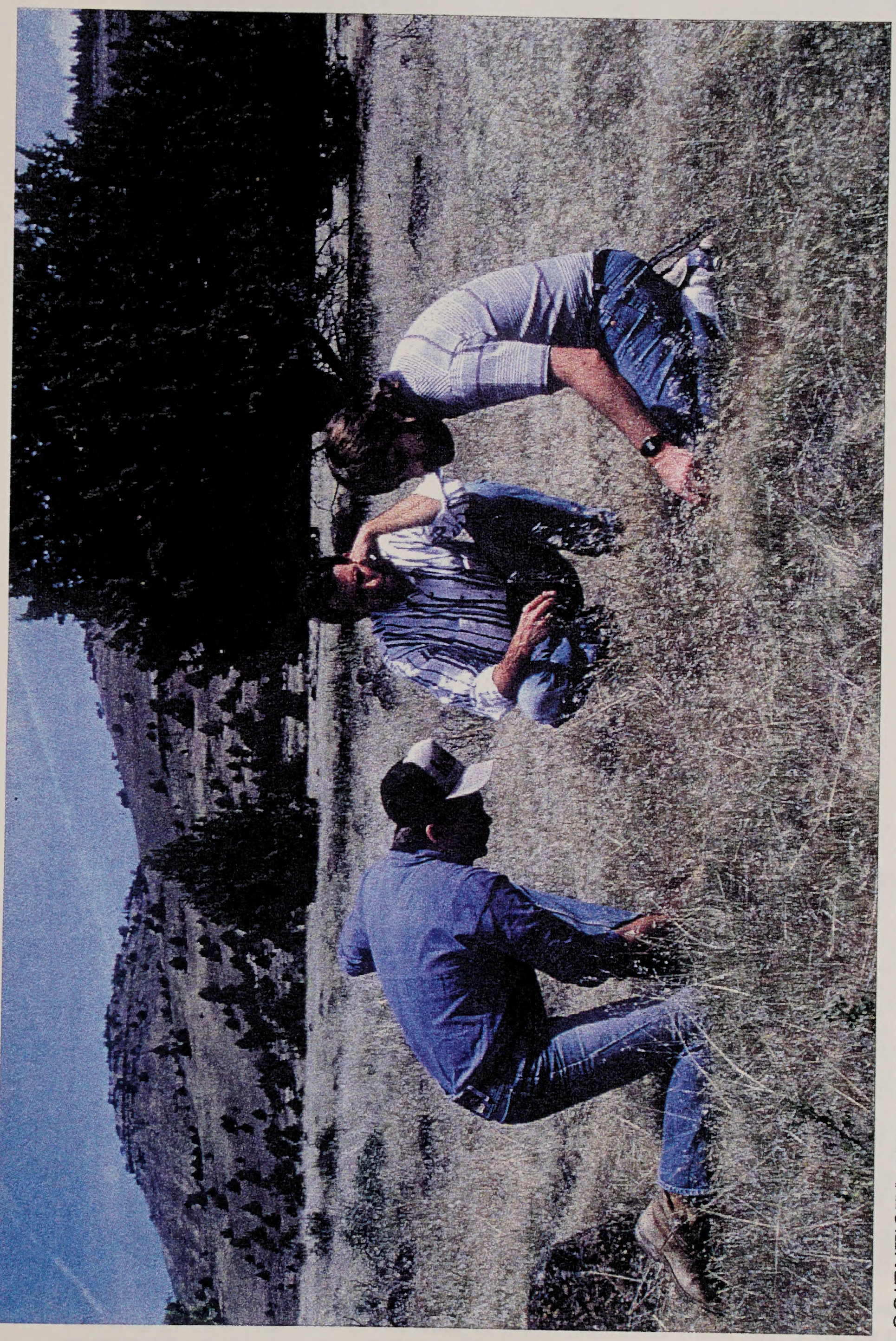

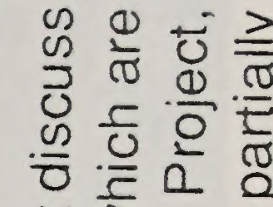

需交 $\frac{1}{0}$

응든 응

음 온군

(1)

능 지

을 0

ब

도 $\$$

त 20.

a) 10

氖焉

두

응

(口) 0

허응 응

응

듀

त必

क

ब

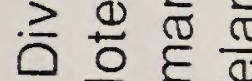

$c^{2} \leq \mathrm{O}$

을 뭉 진

『 $\Phi$

过 0

$>$ (1)

山ن 옹 은

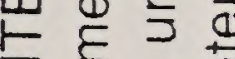

क $>0$

웡

山्

I $\pi$ क

는워

कह क

응

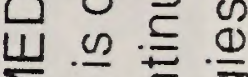

$\sum$ 당

山号 0 응

$\sum \pm$

40

$\times$ ๘

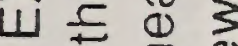

山次

$\omega=\cong$

语

는 $\varepsilon$ 응

0 药

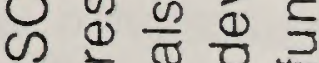





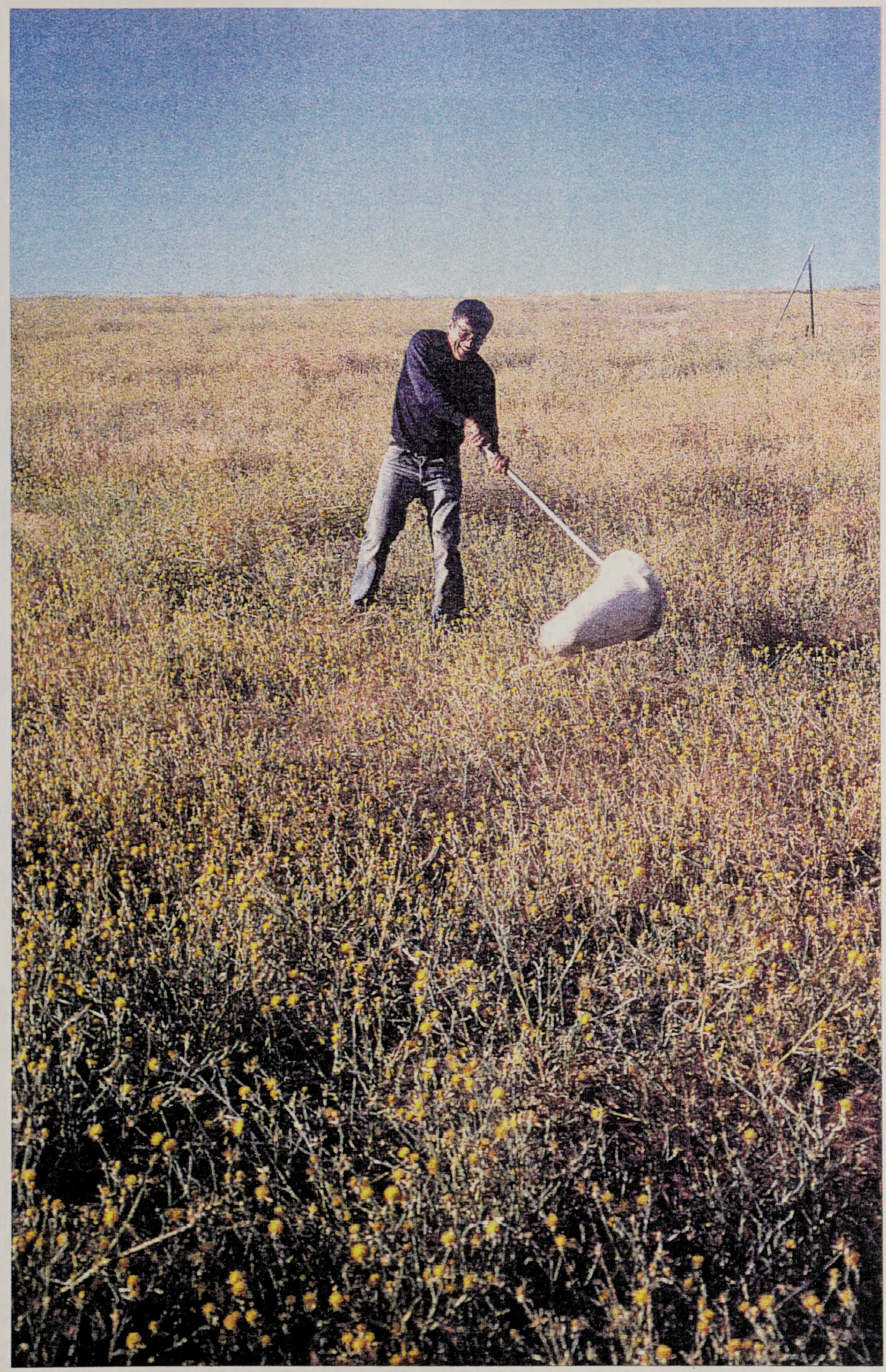

COLLECTING BIOCONTROL AGENTS IN JACKSON CO. Dave Humphrey, Oregon Dept. of Agriculture, is collecting gall flies that attack seedheads of yellow starthistle. These agents will be distributed to other counties. Like many areas in $\mathrm{n}$. California, yellowstar is now so extensive in Jackson Co. that other control methods are not economically or environmentally feasible. Biocontrol efforts, if effective, may bring these populations down to a tolerable level. 


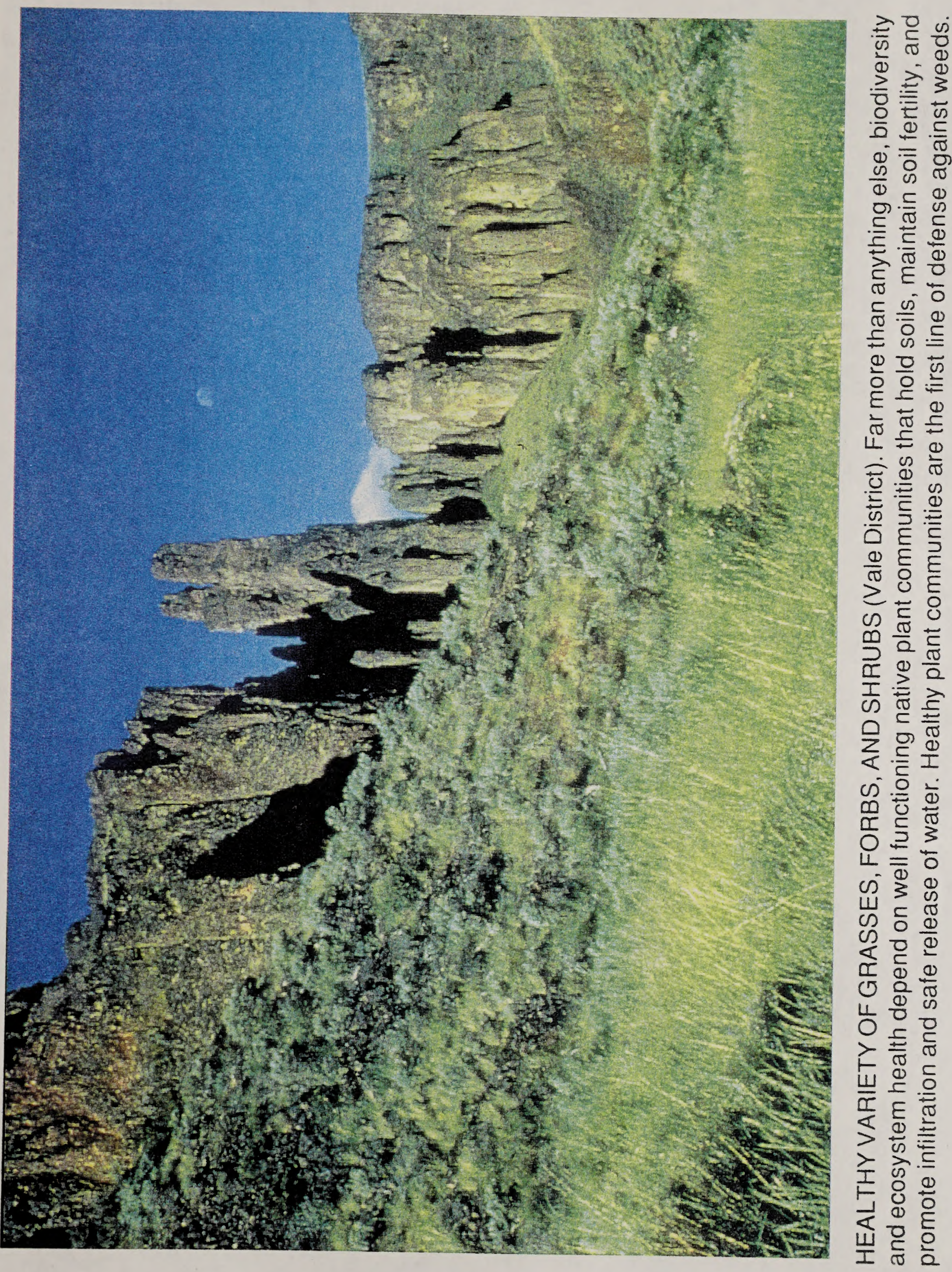




